\title{
Estrogen Receptors and Estrogen-Induced Uterine Vasodilation in Pregnancy
}

\author{
Jin Bai ${ }^{1}{ }^{\circledR}$, Qian-Rong $Q i^{1}{ }^{1}$, Yan Li $^{1}{ }^{1}$, Robert Day ${ }^{1}$, Josh Makhoul ${ }^{1}{ }^{\circledR}$, Ronald R. Magness ${ }^{2}$ \\ and Dong-bao Chen ${ }^{1, *}$ \\ 1 Department of Obstetrics \& Gynecology, University of California, Irvine, CA 92697, USA; \\ baij3@hs.uci.edu (J.B.); qianronq@hs.uci.edu (Q.-R.Q.); liy60@hs.uci.edu (Y.L.); dayr1@uci.edu (R.D.); \\ joshua.makhoul@gmail.com (J.M.) \\ 2 Department of Obstetrics \& Gynecology, University of South Florida, Tampa, FL 33612, USA; \\ rmagness@usf.edu \\ * Correspondence: dongbaoc@uci.edu; Tel.: +949-824-2409
}

Received: 27 May 2020; Accepted: 15 June 2020; Published: 18 June 2020

\begin{abstract}
Normal pregnancy is associated with dramatic increases in uterine blood flow to facilitate the bidirectional maternal-fetal exchanges of respiratory gases and to provide sole nutrient support for fetal growth and survival. The mechanism(s) underlying pregnancy-associated uterine vasodilation remain incompletely understood, but this is associated with elevated estrogens, which stimulate specific estrogen receptor (ER)-dependent vasodilator production in the uterine artery (UA). The classical ERs (ER $\alpha$ and ER $\beta$ ) and the plasma-bound G protein-coupled ER (GPR30/GPER) are expressed in UA endothelial cells and smooth muscle cells, mediating the vasodilatory effects of estrogens through genomic and/or nongenomic pathways that are likely epigenetically modified. The activation of these three ERs by estrogens enhances the endothelial production of nitric oxide (NO), which has been shown to play a key role in uterine vasodilation during pregnancy. However, the local blockade of NO biosynthesis only partially attenuates estrogen-induced and pregnancy-associated uterine vasodilation, suggesting that mechanisms other than $\mathrm{NO}$ exist to mediate uterine vasodilation. In this review, we summarize the literature on the role of NO in ER-mediated mechanisms controlling estrogen-induced and pregnancy-associated uterine vasodilation and our recent work on a "new" UA vasodilator hydrogen sulfide $\left(\mathrm{H}_{2} \mathrm{~S}\right)$ that has dramatically changed our view of how estrogens regulate uterine vasodilation in pregnancy.
\end{abstract}

Keywords: estrogen receptors; estrogens; nitric oxide; hydrogen sulfide; vasodilatation; uterine artery; pregnancy; preeclampsia

\section{Introduction}

During the ovarian cycle, follicular development accompanies phasic persistent hyperemia in the uterine vascular bed. Dramatic hyperemia occurs just prior to and during estrus when preovulatory follicles produce the largest quantity of estrogens [1]. Uterine blood flow (UtBF) sharply elevates during the same period, returns to basal levels after estrus, and remains low during the luteal phase of the ovarian cycle [2] when estrogen levels are at their nadir and progesterone is elevated [3]. During normal pregnancy, maternal hemodynamics change dramatically, characterized by mild decreased systemic blood pressure and a larger fall in systemic vascular resistance, associated with increased heart rate, stroke volume, cardiac output, and blood volume [4-11]. The largest portion ( 15-20\%) of the increased cardiac output is redistributed to the aggressively developing uteroplacental vascular bed, which is reflected by substantial pregnancy-associated periodical rises in UtBF [8,12-14]. Specifically, two peak rises in UtBF that occur during the second and third trimesters correlate, respectively, to the completion 
of placentation and rapid fetal growth $[13,14]$. Noteworthily, circulating and/or local estrogen levels are, coincidentally, elevated with these two UtBF peaks [15-17], suggesting that estrogens may play a pivotal role in regulating UtBF during normal pregnancy.

Markee (1932) was the first to demonstrate the vascular effects of estrogens; he showed that treatment with crude follicular estrogen extracts results in the vasodilatation (hyperemia) of uterine endometrial tissue transplanted to the anterior chamber of the monkey eye [18]. There are now data convincingly showing that estrogens are potent vasodilators that cause blood flow to rise in several organs throughout the body with the greatest effects occurring in reproductive tissues, especially the uterus [9,19-21]. In ovariectomized (OVX) nonpregnant ewes, daily estradiol-17 $\beta\left(E_{2} \beta\right)$ increases basal UtBF by $30-40 \%$ after $6-7$ days in the absence of changes in arterial pressure or heart rate [22] and reduced responses to vasoconstrictors [20,23]. In addition, acute estrogen exposure starts to increase UtBF within 30-40 min, causing an even more robust (up to 10-fold maximum) rise in UtBF within 90-120 min after a bolus intravenous injection of $1-3 \mu \mathrm{g} / \mathrm{kg} \mathrm{E} \mathrm{E}_{2} \beta$; this acute estrogen $(1 \mu \mathrm{g} / \mathrm{kg})$-induced rise in UtBF declines gradually within $3-8 \mathrm{~h}$ after injection $[24,25]$ and is independent of systemic responses [9]. The uterine vasodilatory effect of estrogens is of major physiological significance during the follicular phase of the ovarian cycle and pregnancy, in which circulating estrogens are significantly elevated [17,25-27]. During normal pregnancy, substantially increased endogenous estrogens are believed to be key players for upregulating UtBF, which provides the sole source of nutrients and oxygen supplies for the fetus and the exit of the metabolic wastes and respiratory gases of the fetus. UtBF is a critical rate-limiting factor for pregnancy health because (1) a dramatic rise in UtBF, especially in the last third of gestation, is directly linked to fetal growth and survival; and (2) insufficient rises in UtBF are associated with preeclampsia, intrauterine growth restriction (IUGR), and other pregnancy disorders, affecting the health of the infant after birth [28]. Notably, babies born to mothers with complicated pregnancies are predisposed to a significantly increased risk of developing cardiometabolic diseases, including cardiovascular diseases such as high blood pressure and coronary diseases, as well as type II diabetes [29]. From a nutrition standpoint, for supporting fetal development, constrained UtBF should be viewed as a "physiological" under-nutrition condition in fetal programming using the Barker hypothesis [30]. Thus, mechanistic investigations into estrogen-induced uterine dilatation during pregnancy will assist in the identification of therapeutic targets or even preventive options for pregnancy disorders.

The mechanisms by which estrogens regulate uterine hemodynamics during pregnancy are complex and not fully understood. Numerous physiological and pharmacological studies have accumulated compelling evidence demonstrating that an estrogen-induced rise in UtBF is associated with increased local uterine artery (UA) endothelial production of vasodilators such as prostacyclin [31], nitric oxide (NO) [32], carbon monoxide (CO) [33], endothelium-derived hyperpolarizing factor (EDHR) [34], etc. It has previously been shown that NO plays a more important role than prostacyclin in mediating the estrogen-induced rise in UtBF since the estrogen-induced rise in UtBF in nonpregnant sheep [9,32,35], the rise in UtBF in sheep during pregnancy [35], and the rise in the forearm blood flow in pregnant women [36] can be significantly attenuated by NO synthase inhibitors, but not by the prostaglandin synthase inhibitor indomethacin (8). Notably, NO inhibition maximally attenuates only $\sim 79 \%$ of the estrogen-induced rise in UtBF [32] and modestly ( 26\%) inhibits baseline pregnancy-associated uterine vasodilation [35], clearly suggesting that additional mechanisms are involved. To this end, our novel work has recently identified that augmented hydrogen sulfide $\left(\mathrm{H}_{2} \mathrm{~S}\right)$ production functions as a "new" UA vasodilator [37], which may offer great potential for uterine hemodynamic regulation. Nonetheless, our previous studies have shown that local infusion of the ER antagonist ICI 182, 780 can dose-dependently attenuate the estrogen-induced rise in UtBF in nonpregnant OVX and the pregnancy-associated rise in UtBF in intact pregnant ewes [25], suggesting that specific estrogen receptors (ERs) are involved in the estrogen regulation of uterine vasodilation in pregnancy.

The aim of this review is to summarize the literature on UA ERs with a focus on their roles in mediating the local UA production of vasodilators by estrogens and pregnancy and to deliberate 
on the potential clinic implications of dysregulated ER-mediated estrogen signaling in hypertensive pregnancy complications.

\section{Classical ERs-ER $\alpha$ and ER $\beta$ in Uterine Vasodilation in Pregnancy}

The biological functions of estrogens were initially identified to be mediated through the classical ERs, i.e., ER $\alpha$ and $E R \beta$, which are ligand-dependent transcription factors. Both ER $\alpha$ and $E R \beta$ have been found in many species, including mammals (e.g., human [38], sheep [39], mouse [40] and rat [41]) and non-mammals such as chicken [42], xenopus [43], and fish [44]. ER $\alpha$ and ER $\beta$ are distinct proteins encoded by two distinct genes; in humans, the $66 \mathrm{kD}$ ER $\alpha$ protein is encoded by ESR1 (chromosome locus 6q25.1) and the $55 \mathrm{kD}$ ER $\beta$ protein is encoded by ESR2 (chromosome locus 14q23-24.1) [45,46]. The amino acid sequences of ER $\alpha$ and ER $\beta$ display a $59 \%$ sequence identity in their respective ligand binding domains (LBD), which represents a significant difference [47]. ER $\alpha$ and ER $\beta$ are expressed in a variety of tissues and cells, corresponding to the diverse biological effects of estrogens in numerous organs and cells throughout the body. In addition, ER $\alpha$ and ER $\beta$ show distinct expression patterns among different organs. ER $\alpha$ is predominantly expressed in pituitary, kidney, and both male and female reproductive systems such as the epididymis, testis, uterus, ovary, and breast, whereas ER $\beta$ is widely expressed in the reproductive system and brain [48]. The expression levels of ER $\alpha$ and ER $\beta$ are highest in the ovary and uterine endometrium, consistent with the fact that the female reproductive system is the primary target of estrogens $[38,45]$.

There are also various variants of both ERs. ER $\alpha 36$ is a $36-\mathrm{kDa}$ amino-terminal truncated product of the full-length ER $\alpha$ protein (ER $\alpha 66)$, mainly located in the cell membrane and cytoplasm. ER $\alpha 36$ lacks the transactivation domain of ER $\alpha 66$ as well as the intrinsic transcriptional activity of estrogens, thereby competing with ER $\alpha 66$ to regulate the expression of genes with estrogen-responsive elements (EREs) in their promoter [49]. On the other hand, the overexpression of ER $\alpha 66$ suppresses the transcription of $E R \alpha 36$, which can be recovered by the forced expression of ER $\alpha 36$, independent of estrogens [50]. Moreover, ER $\alpha 36$ can mediate the estrogen activation of the extracellular signal-regulated kinases $\frac{1}{2}$ $\left(E R K \frac{1}{2}\right)$ [49] and phosphoinositide 3-kinases (PI3K)/protein kinase B (PKB/AKT) [51] pathways. ER $\alpha 46$ is another amino-terminal truncated product of ER $\alpha 66$ with a molecular weight of 46-kDa. ER46 has been identified in the vascular endothelial cells (EC) as a mediator of endothelial NO synthase (eNOS) activation in order to encourage the production of NO by estrogens [52]. Apart from ER $\alpha 36$ and ER $\alpha 46$, $\mathrm{ER} \Delta 7$ is another recently reported $51-\mathrm{kD}$ variant of ER $\alpha 66$ with the exclusion of exon 7; it acts as a dominant negative repressor of the uterotonic action in myometrium [53]. The physiological concentrations (100-700 pmol/L) of serum estrogens during the menstrual cycle can only bind to ER $\alpha 46$ and ER $\alpha 66$, but not to ER $\alpha 36$ [54], which can only bind with $\mathrm{E}_{2} \beta$ at a relatively high $\mathrm{kD}$ of $2.2 \mathrm{nM}$ compared to the physiological levels of serum estrogens [55]. Meanwhile, ER $\alpha 36$ can activate mitogen-activated protein kinase (MAPK) pathways in the presence of the inactively isomeric E2 $\beta 17 \alpha$-estradiol [49] and testosterone [51] at the same concentration of $E_{2} \beta$, suggesting that $E R \alpha 36$ is not the target for estrogenic actions in the physiological state, but merely acts as a membrane-associated ER. Nonetheless, whether this variant is expressed and has a functional role in the vasculature are currently unknown.

Other distinct ER subtypes have also been described. A novel ER subtype ER $\gamma$ has been widely documented in fish species, including Atlantic croaker [56], zebrafish [57], and largemouth bass [58]. However, this ER $\gamma$ has hitherto not been found in mammals. In addition, a brain ER isoform called ER-X has been described to be encoded by a distinct human gene [59]; however, this has not been found in other tissues and little is known regarding its function(s). Another isoform called putative ER (pER) has also been identified to possess distinct characteristics from that of ER $\alpha$ and ER $\beta$ [60]. pER has been reported in the ovary, but not any other reproductive tissues including the reproductive vasculature [60]. Thus, these ER subtypes are not discussed further in this review.

Uterine arteries, like all other large blood vessels, are comprised of a single concentric layer of EC that are surrounded by multilayers of smooth muscle cells (SMC). ER $\alpha$ and ER $\beta$ have been found in EC and SMC in various vascular beds, indicating that EC and SMC are the direct target cells of 
estrogens [61-63]. In addition, the membrane-bound G protein-coupled estrogen receptor 1 (GPER) has also been reported to be located on the plasma membrane, presumptively mediating the nongenomic effects of estrogens [64]. Thus, the vascular effects of estrogens are mediated by both "genomic" and "nongenomic" pathways. The presence of all three of these ERs has been documented in UA endothelial cells (UAEC) and UA smooth muscle cells (UASMC) in vivo [65-67]. Both ER $\alpha$ and ER $\beta$ and GPER are also expressed in various systemic arterial EC and SMC in vivo, including carotid, pulmonary, mesenteric, and renal arteries [68,69], and their expression levels are regulated in pregnancy in a vascular bed-specific manner [69]. We were the first to report both ER $\alpha$ and ER $\beta$ expressions in the UA endothelium and smooth muscles (SMs) in pregnant ewes ex vivo [39], which are retained in cultured primary ovine UAEC and UASMC in vitro. In that study, using immunoblotting with epitope-specific antibodies, we showed that a native ER $\alpha$ protein $(67 \mathrm{kDa})$ is expressed in sheep UA, purified UA endothelium, and retained in UAEC in culture, similar to sheep ovary extracts (Figure 1A). However, we observed the presence of several ER $\beta$ protein bands in the extracts of these tissue samples and cells (Figure 1B), including the molecular weight of the 55-kDa band of the native full-length ER $\beta$ protein. Moreover, an additional ER $\beta$ band with a molecular weight of $\sim 30 \mathrm{kDa}$ was also detected in these samples. We named the 55-kDa band ER $\beta 1$ and the $~ 30-k D a$ band ER $\beta 2$ (Figure 1B). We also detected additional bands (Figure 1; indicated with *) with the specific anti-ER $\beta$ antibody, which could be other variants of ER $\beta$ (Figure 1B). Using RT-PCR and sequencing analysis, we confirmed these findings and showed that the ER $\beta 2$ protein represents a $N$-terminal truncated ER $\beta$ protein due to a 139-bp splicing deletion of exon 5 (Figure 1B,D-F). More recently, we also reported the functional roles of ER $\alpha$ and $E R \beta$ in cultured UASMC in vitro [70]. Collectively, these results indicate the presence of both ER $\alpha$ and ER $\beta$ proteins in sheep UA, UA endothelium and SM ex vivo, which are retained in cultured UAEC and UASMC in vitro.

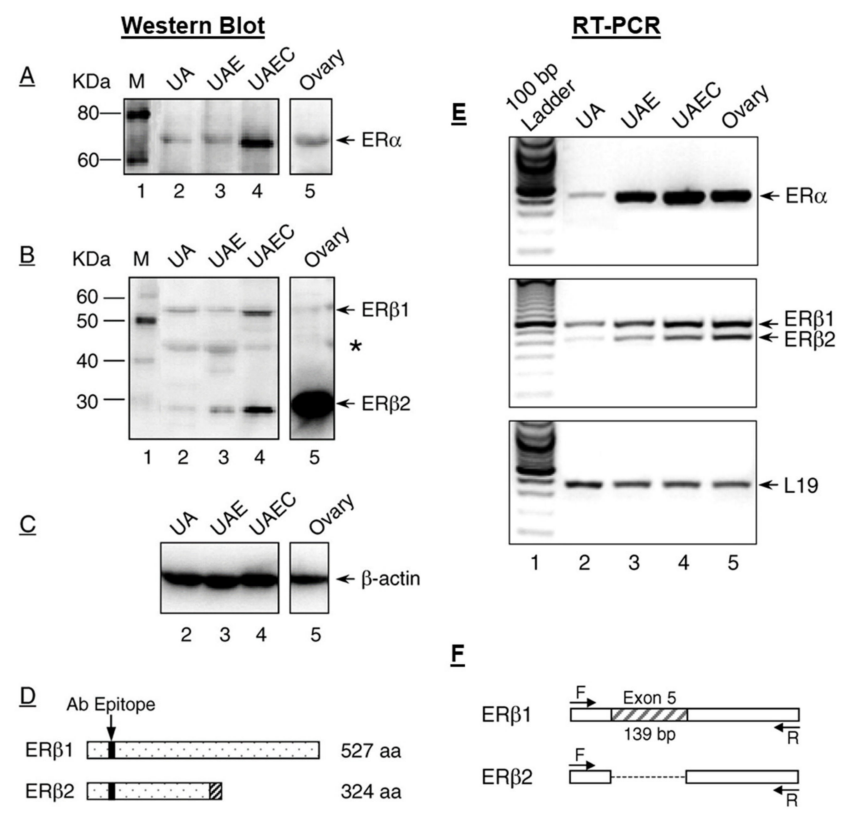

Figure 1. Uterine artery estrogen receptors. Estrogen receptor (ER) $\alpha(\mathbf{A})$ and ER $\beta(\mathbf{B})$ proteins in the protein extracts of intact uterine artery (UA), purified UA endothelium (UAE), cultured UA endothelial cells (UAEC), and ovary from pregnant ewes detected by Immunoblotting with epitope specific antibodies. $\beta$-actin (C) was used as loading control. (D) A diagram representing the truncated form of ER $\beta 2$ that results from the splicing deletion of exon 5 . The shadowed box represents the amino acid sequences encoded by different reading frame. (E) ER $\alpha$ and ER $\beta$ mRNAs detected by RT-PCR with the ribosomal protein L19 as loading control. (F) A diagram shows a 139bp deletion of Exon 5 in ER $\beta 2$ mRNA vs. the native ER $\beta 1$. Uterine artery (UA); UA endothelium (UAE); UA endothelial cells (UAEC); amino acid (aa). Bands marked with * may indicate additional truncated forms of ER $\beta$. Adopted from Liao et al. [71]. 
In vivo, ICI 782, 180 dose-dependently inhibits exogenous and endogenous $\mathrm{E}_{2} \beta$-stimulated UtBF responses in nonpregnant OVX and intact ewes, respectively, demonstrating specific ER-mediated mechanisms for estrogens to cause uterine vasodilation. Moreover, we reported that ICI 780, 182 also dose-dependently attenuated baseline pregnancy-associated UtBF in ewes, showing a role of classical ERs in endogenous estrogen maintenance of uterine vasodilation during gestation [25]. Many ex vivo studies using wire myography recapitulate the rapid vasorelaxation effects of estrogens in uterine arteries and in selected systemic arteries such as mesenteric arteries [37]. Overall, these studies concluded that there was an involvement of classical ERs blocked by ICI 182, 780 mediating the $E_{2} \beta$-induced relaxation of freshly prepared UA rings that have been pre-constricted by phenylephrine or other vasoconstrictors. Except for one early study [72], most have shown that pregnancy potentiates the vasorelaxant effects of estrogens including estetrol $\left(\mathrm{E}_{4}\right)$ and $\mathrm{E}_{2} \beta$ with relatively high potency in UA, which are sensitive to inhibition by ICI 182, 780 [25,73].

ER-mediated estrogen signing promotes uterine vasodilation [74]. In $E R \alpha$-deficient mice, rapid estrogen-stimulated endothelial NO-dependent vasodilatation was significantly reduced $[75,76]$. In $E R \beta$-deficient mice, estrogens even augmented phenylephrine-preconstricted dose-dependent vasoconstrictive effects in denuded aortic rings [77]. These data, obtained with ER knockout mouse models, show that $\mathrm{ER} \alpha$ and $\mathrm{ER} \beta$ may differentially mediate the responses of various vascular functions manifested by estrogens. ER $\alpha$ and ER $\beta$ often exhibit functional homogeneity and heterogeneity among different cells or tissues in mediating the effects of estrogens.

Specific ER $\alpha$ and ER $\beta$ agonists and antagonists are highly desirable and critically useful tools for discriminating the specific roles of ER $\alpha$ and ER $\beta$ in the complexity of estrogen signaling. Many synthetic compounds have been developed to preferentially bind ER $\alpha$ and ER $\beta$. Specific agonists, propylpyrazoletriol (PPT) for ER $\alpha$ [78], and diarylpropionitrile (DPN) for ER $\beta$ [79], and specific antagonists, 1,3-bis(4-hydroxyphenyl)-4-methyl-5-[4-(2-piperidinylethoxy)phenol]-1H-pyrazole dihydrochloride (MPP) for ER $\alpha$ [80], 4-[2-phenyl-5,7-bis (trifluoromethyl)pyrazolo [1,5-a]pyrimidin-3yl] phenol (PHTPP) for ER $\beta$ [81], are pharmacological probes used frequently to define the specific roles of $E R \alpha$ and $E R \beta$ in mediating estrogen actions in vitro and in vivo.

Studies using specific ER $\alpha$ and ER $\beta$ agonists and antagonists have implicated clearly different roles of $E R \alpha$ and $E R \beta$ in the vasorelaxant effects of estrogens in the uterine and placental circulations. In human myometrial uterine arteries (arcuate/radial arteries), $\mathrm{E}_{2} \beta$, PPT (agonist for ER $\alpha$ ), or DPN (agonist for ER $\beta$ ) each induce comparable dose-dependent $(1 \mathrm{nM}-30 \mu \mathrm{M})$ relaxations that are pre-constricted by the thromboxane receptor agonist U46619 $(1 \mu \mathrm{M})$. These findings suggest that both $\mathrm{ER} \alpha$ and $\mathrm{ER} \beta$ are involved in UA dilation in pregnant human uterine arteries. $\mathrm{E}_{2} \beta$ can also relax human placental arteries, but with significantly lower potency than myometrial arteries. Although both $E R \alpha$ and $E R \beta$ are expressed in human placental arteries, it seems that $E_{2} \beta$-induced placental artery relaxation is mediated by ER $\beta$, because DPN can relax placental arteries, whereas PPT is without an effect [82]. Interestingly, the classical ER-mediated vasodilatory effects of estrogens are diminished in uterine and resistant mesentery arteries in chronologically aging rats and postmenopausal women [83]. Nonetheless, these findings suggest that ER $\alpha$ and ER $\beta$ differentially modulate the vascular tone in the uterine and placental arteries, highlighting that estrogens regulate human uterine and placental blood flows in a tissue-specific manner.

\section{Membrane ERs and Estrogen-Induced Uterine Vasodilation in Pregnancy}

Following estrogen administration, UtBF begins to rise as early as $5-15 \mathrm{~min}$, then reaches maximum levels around 90-120 min in various animal studies [2,9,20,21,24,84-86]. Nuclear ER-mediated estrogen signaling seems unable to explain this rapid vascular estrogenic response as de novo protein synthesis via nuclear ER-mediated gene transcription would take hours to take place. Moreover, cycloheximide completely abrogated the local estrogen-mediated rise in UtBF in the OVX ovine model [24]. Therefore, mechanistic studies have speculated that an estrogen-induced rapid rise in UtBF must be mediated by rapid estrogen signaling mediated by receptors localized on the plasma 
membrane. Indeed, estrogens can initiate rapid responses, such as calcium mobilization [87] and the generation of second messenger cyclic guanosine monophosphate (cGMP) [88] and cyclic adenosine $3^{\prime}, 5^{\prime}$-monophosphate (cAMP) [89] in various cells in vitro and in animals in vivo. Early mechanistic studies with the use of $E_{2} \beta$-conjugated to bovine serum albumin ( $E_{2} \beta$-BSA) have shown that rapid estrogen signaling responses are mediated by classical ERs localized on the plasma membrane [90]. $E_{2} \beta$-BSA is membrane impermeable and is widely used to demonstrate the presence of membrane ER, although free $E_{2} \beta$ is always a concern [91]. Nonetheless, there is solid evidence that both ER $\alpha$ and ER $\beta$ are present on the plasma membrane. In vascular EC, ER $\alpha$ has been shown to be partitioned into the specialized plasma microdomains, called caveolae, by interacting with caveolin-1 directly [71,92,93]. Both the plasma membrane-bound ER $\alpha$ and ER $\beta$ are responsible for the estrogen-stimulated rapid release of NO in UAEC in distinct ways [94]; however, the importance of this pathway in uterine vasodilation is unclear.

In 1997, a membrane receptor called G protein-coupled ER (GPR30/GPER) was initially cloned [95], which binds estrogens. The human GPR30 gene is located at chromosome 7p22.3, which is composed of three exons in which the exon 3 contains its amino acid coding region. Interestingly, the region of the chromosome containing GPR30 is thought to be related to familial hypertensive disease in humans $[96,97]$. GPR30 is an orphan receptor without known endogenous ligands; it has been proposed to be a bona fide membrane estrogen-binding receptor [97-99] and thus was renamed GPER by the International Union of Basic and Clinical Pharmacology [100]. GPER mRNA is widely expressed throughout the body, including in the lungs, liver, prostate, ovary, placenta, uterus and its vasculature [95,101-103], as well as ER-positive tumor cell lines [104]. Thus, it is not a surprise that GPER plays a ubiquitous role in the reproductive, nervous, endocrine, immune, and cardiovascular systems. Similar to classical ERs, GPER transcripts have been found in the vasculature throughout the cardiovascular system [105-107], including in the uterine arteries and veins [108]. Although both arteries and veins have shown GPER expression, only artery GPER expression is reduced by $E_{2} \beta$ [109], suggesting that local GPER might be fundamental in regulating estrogenic responses such as uterine vasodilation during pregnancy. However, GPER knockout has shown a minimal effect in regulating uterine growth by estrogens in mice [105,110-112]. We therefore suggest that GPER may function together with classical ERs in regulating uterine biology.

Although its cellular localization is still controversial, GPER has been regarded as a specific membrane estrogen receptor [98]. Although GPER interacts with $E_{2} \beta$ with estimated binding affinities of 3-6 nM [64], this is much lower compared with its binding affinities for classical ERs that are in the range of $0.1-1.0 \mathrm{nM}$ [48]. It also interacts with anti-estrogens such as tamoxifen and the nonspecific ER antagonist ICI 782,180 [64], as well as many other estrogen receptor modulators [113], which makes it difficult to elucidate the specific role of GPER in target cells. Thus, the development of specific pharmacological tools, including the highly selective GPER agonist G-1 and antagonist G-15 [114], has greatly facilitated the characterization of GPER function. G-1 binds GPER with high affinity $(\mathrm{Kd}=10 \mathrm{nM})$ without binding to $\mathrm{ER} \alpha / \beta$ at concentrations as high as $10 \mu \mathrm{M}$ [115], whereas $\mathrm{G}-15$, with a similar structure as G-1, but lackingthe ethanone moiety that forms hydrogen bonds involved in receptor activation (103), displays a $\mathrm{Kd}>10 \mu \mathrm{M}$ for binding $\mathrm{ER} \alpha / \beta$ [116].

Global GPER-knockout mice develop high blood pressure [112], atherosclerosis progression, and systemic inflammation [117], suggesting that GPER exerts cardioprotective effects. This conclusion is further supported by the fact that cardiomyocyte-specific GPER deletion results in an abnormal cardiac structure and impaired systolic and diastolic function in mice [118]. GPER may mediate the direct vasodilatory effect of estrogens in multiple vascular beds. Acute G-1 infusion decreases blood pressure in male rats, while the long-term injection of G-1 decreases mean arterial pressure in the hypertensive OVX female rats. These findings suggest that the activation of GPER potentially protects estrogen-deficient females from hypertension in rats [119]. In humans, G-1 dilates mammary arteries and, notably, G-1 dilates the precontracted human aorta and carotid artery more potently than $\mathrm{E}_{2} \beta[120]$. 
The first study attempting to specifically demonstrate the role of membrane ER-mediated signaling in uterine dilation was not successful in using wire myography to show a dilatory effect of $E_{2} \beta$-BSA in freshly isolated nonpregnant and pregnant rat UA rings ex vivo [72]. However, GPER is expressed in the EC and SMC of mesenteric microvessels of female rats and was shown to mediate much of the $E_{2} \beta$-induced dilation [121]. G-1 induces the dose-dependent relaxation of freshly prepared uterine radial artery rings isolated from both nonpregnant and pregnant rats that were pre-constricted with phenylephrine. Moreover, the expression levels of GPER protein were demonstrated to be greater in pregnant vs. nonpregnant radial arteries and the dilatory effect of G-1 in pregnant rat uterine radial arteries was more potent than that in nonpregnant ones [108]. These findings establish a casual role of GPER in pregnancy-dependent UA vasodilation in the rat model.

Although ER $\alpha$ has been shown to be localized on the plasma membrane of UAEC in in vitro culture $[39,93]$, the importance of membrane-targeted ER $\alpha$ in estrogen-induced uterine dilation is yet to be fully determined. ER $\beta$ is also localized on the plasma membrane in other types of EC such as bovine aortic EC [122] and non-EC cancer cells [123]. In colon cancer cells, Galluzzo and her colleagues found that $E_{2} \beta$ could stimulate the association between $E R \beta$ and caveolae signature protein caveolin-1 [123]. Nonetheless, a recent study did not find direct ER $\beta$ targeting to the plasma membrane caveolae in UAEC [93]. Thus, it is highly likely that the role of ER $\beta$ in rapid uterine vasodilation to estrogen, if any, is an indirect mechanism that is yet to be determined.

\section{Signaling Pathways of Estrogen Action}

Estrogens signal via both "genomic" and "nongenomic" pathways in target cells expressing the classical ERs (ER $\alpha$ and ER $\beta$ ) and the membrane-bound GPER. The genomic pathway is mediated by $E R \alpha / E R \beta$ in the nucleus of target cells, where the ligated receptors function as ligand-activated transcription factors to regulate gene expression via direct interactions with estrogen-responsive elements (EREs) or indirect interactions with other response elements by binding with their respective transcription factors (e.g., specificity protein 1 (SP-1) and activator protein 1 (AP-1)) in the promoter of gaseous vasodilator synthesizing-enzyme genes such as eNOS and cystathionine $\beta$-synthase (CBS) [71,124] (Figure 2, route 1: nuclear actions).

Nonetheless, in some cell types, ER $\alpha$ and ER $\beta$ may play differential and, in some cases, even opposite roles in regulating cellular responses to estrogens [125]. In addition, estrogens can also signal via ER-independent routes by transactivating receptor tyrosine kinases (RTK) such as insulin-like growth factor 1 (IGF1) [126] and epidermal growth factor (EGF) [127] receptors (Figure 2, route 2: ER-independent manner).

As shown in Figure 2, route 3: non-nuclear actions, the nongenomic estrogen signaling is mediated by ERs $(E R \alpha$ and $E R \beta)$ localized at the plasma membrane $[113,128]$, presumptively partitioned in the plasma membrane microdomain called caveolae via the binding between ER $\alpha$ and caveolin- 1 in various cell types $[90,92,93,123]$. Nongenomic estrogen signaling is also mediated by the plasma membrane GPER. In this "extranuclear" mode, estrogen signaling is initiated in between seconds and minutes to activate downstream target proteins and elicit biological functions, presumably independent of nuclear events. Membrane ER-mediated nongenomic signaling can integrate with nuclear ER-mediated gene transcription via the protein kinase-mediated phosphorylation of ER and other ER-interacting transcription factors such as AP-1, SP-1, and cAMP response element-binding protein (CREB) to regulate latent gene expression in target cells in shown in Figure 2, route 4: cross-talk [129].

\subsection{Nuclear ER Actions in $U A$}

$\mathrm{ER} \alpha$ and ER $\beta$ belong to the nuclear receptor superfamily principally consisting of three conserved functional domains, namely the $N$-terminal transactivation domain (NTD), the DNA-binding domain (DBD) and the ligand-binding domain (LBD) $[130,131]$. A conformational change occurs first, inducing receptor dimerization by the binding of $E_{2} \beta$ to $E R \alpha$ or ER $\beta$ in the cytoplasm [132]. When translocated into the nucleus, these $E_{2} \beta$-bound ER dimers transactivate target genes that possess estrogen-responsive 
elements (EREs) within their promoters with a consensus sequence (5'-GGTCAnnnTGACC-3') by interacting with DBD $[133,134]$; this transactivation is referred as "genomic" and was originally described for transcription factors. Besides promoters, EREs can also be located in the enhancer regions and/or the $3^{\prime}$ untranslated region of the target genes [135].

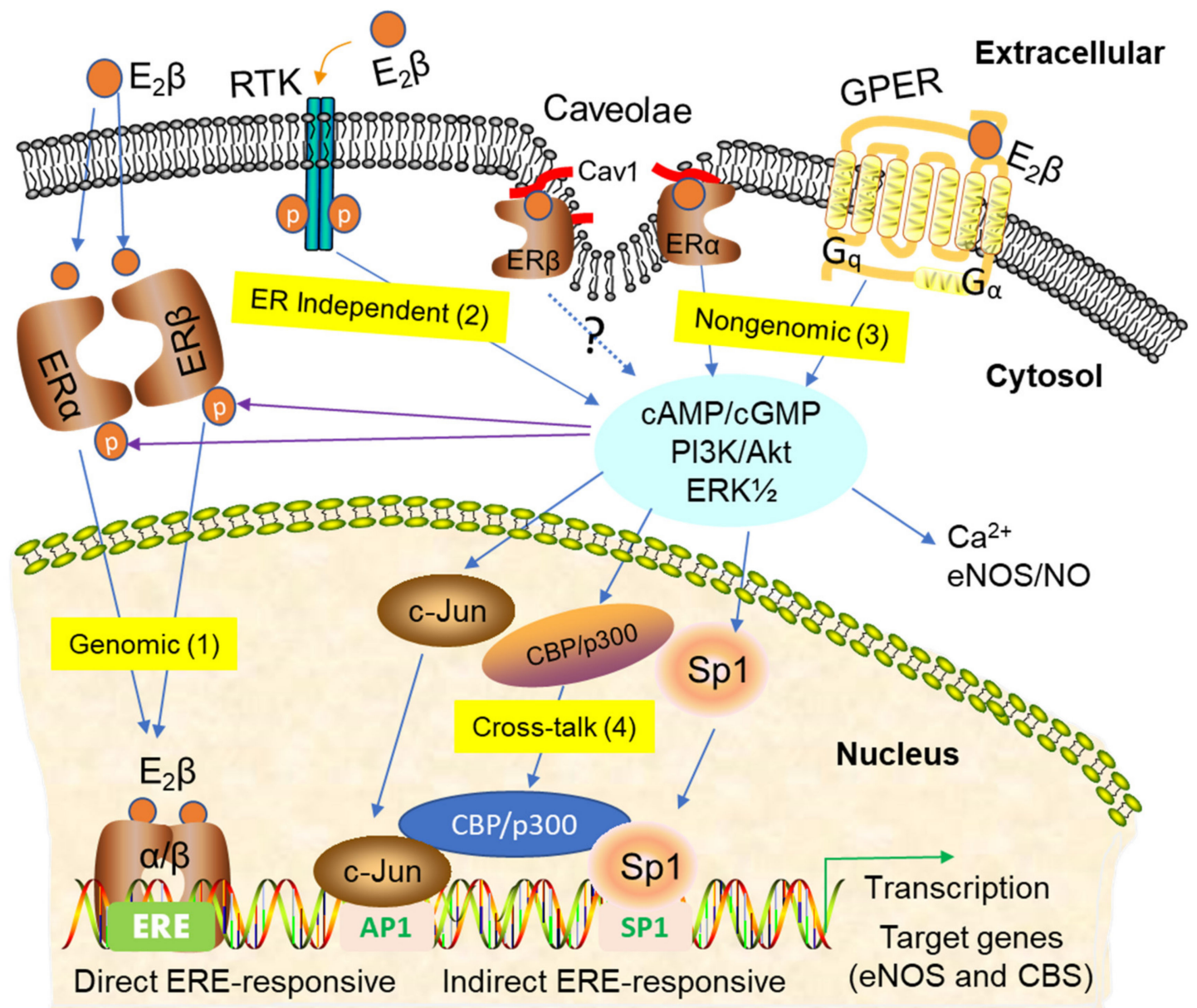

Figure 2. Signaling pathways of estrogen actions. There are different signaling mechanisms that mediate estrogen actions, including (1) nuclear actions: estrogen receptor (ERs) bind estrogens; liganded ERs translocate to the nucleus where they form homo- or heterodimer transcription factors to induce the transcription of estrogen-responsive genes with or without estrogen-responsive elements (EREs), (2) ER-independent estrogen signaling: estrogen transactivates receptor tyrosine kinases (RTKs, i.e., epidermal growth factor receptor and fibroblast growth factor (EGFR and FGFR)) to initiate ER-independent signaling such as an increase in second messengers cAMP and guanosine monophosphate (cGMP) the and activation of protein kinase cascades such as extracellular signal-regulated kinases $\frac{1}{2}$ (ERK $\frac{1}{2}$ ) and phosphoinositide 3-kinases (PI3K)/protein kinase B (AKT), (3) extranuclear nuclear nongenomic actions: estrogens binds to plasma membrane ERs, including ER $\alpha$ and ER $\beta$, and G-protein-coupled estrogen receptor (GPER), resulting in increase in second messengers and activation of protein kinase cascades, and (4) interactions between nuclear and extra-nuclear estrogen signaling pathways: ER-independent estrogen signaling via transactivation of RTKs and plasma membrane ER-dependent nongenomic estrogen signaling can interact with nuclear estrogen signaling via protein kinase-mediated ER phosphorylation and activation of gene transcription via ER-interacting transcription factors such as activator protein-1 (AP-1) and specificity protein-1 (SP-1).

The genomic effects of estrogens via classical ERs provide the maintenance of vasodilation via the upregulation of key enzyme gene/protein expressions, which are regulated to keep the vasodilatation/vasoconstriction balance for the vascular tone [136]. Although both the homodimer 
and heterodimer of ER $\alpha$ and ER $\beta$ have been found to bind with the consensus palindromic ERE or half-palindromic ERE $[137,138]$, the preference of the chromatin-binding spectrum does exist and has been found to be ER isoform-specific and ligand-dependent [139]. To further analyze this, the Grober lab generated the most significant position-specific probability matrix using multiple expectation maximization for motif elicitation (MEME) to make a comparison with the counterparts present in the transcription factor-binding profile database called JASPAR [140], and found that the ERE matrices derived from $E R \alpha$ selective, ER $\beta$ selective and $E R \alpha+E R \beta$-binding regions were identical, though $E R \beta$ failed to show ERE variant selectivity consequentially [140]. Although the consensus sequences of ERE share a high similarity, slight changes in the intrinsic sequence composition can alter the binding affinity for ER to ERE [141]. This moderately explains why the transcriptional roles of ER $\alpha$ and ER $\beta$ in mediating the same target of $\mathrm{H}_{2} \mathrm{~S}$-synthesizing enzyme gene expression to promote UA dilation are different for UAEC and UASMC [70,142].

Upon (or prior to) binding to ERE, ERs also show the ability to interact with other transcription factors such as SP-1 and AP-1, in a process referred to as transcription factor crosstalk, to initiate gene transcription independent of EREs [143-146]. One of the typical crosstalk events is facilitated by the binding of transcription factors to the GC-rich regions located in the promoter of the target gene with the presence of ERs [147]. For example, estrogens can stimulate eNOS [148] and cystathionine- $\gamma$-lyase (CSE) [149] expression by promoting the binding of SP-1 with its respective binding site in the promoter of the target gene. Another crosstalk event is functioned by a complex composed of ER and other transcription factors such as c-Fos, c-Jun and AP-1 [150,151]. In addition to the formation of a complex by protein-protein interaction between ERs and other transcription factors, the co-activator role (e.g., FoxA1) can also assist in creating accessible regions of the chromatin that ER $\alpha$ binds with to strengthen the physical interaction of ER with chromosome DNA [152,153].

\subsection{Non-Nuclear ER Actions in UA}

Since some estrogen-responsive genes do not have ERE-containing promoters, and intracellular responses of second messenger signal transductions to estrogen occur within minutes [154,155], the enzymatic pathways through the activation of membrane-associated ER are thought not to involve the direct ER activation of gene transcription and are referred to as "rapid" or "nonnuclear" ER signaling. Ligand binding by estrogens elicits conformational changes in ERs, which, in turn, are believed to interact with their neighboring signaling kinases (e.g., MAPK/ERK $\frac{1}{2}$, PI3K and Akt) leading to the activation of downstream cascades. Although both cell surface-bound ER $\alpha$ and ER $\beta$ exist in the human UA endothelium and no correspondence for ER $\beta$ has been found in caveolae [93], both ER $\alpha$ and ER $\beta$ may play regulatory roles in mediating nongenomic effects.

Since ER $\alpha$ and ER $\beta$ do not contain a trans-membrane domain [93] and are irrelevant with myristylation or prenylation [156], their ability to anchor signaling proteins at the endothelial membrane are mainly contributed by palmitoylation at the caveolae, the $\Omega$-shaped invagination commonly present in EC [157]. However, most studies about the role of ER in caveolae focus on ER $\alpha$ associated with caveolin, the principal residual protein of caveolae, and eNOS [158,159]. In EC, caveolae-localized $\mathrm{ER} \alpha$ activate PI3K, Akt and ERK $\frac{1}{2}$, subsequently enhancing the eNOS/NO pathway [90,160-163]; a similar study showed yjsy the pregnancy-specific changes in vasodilator production are associated with differences in $\mathrm{Ca}^{2+}$ and ERK $\frac{1}{2}$ signaling [164]. On the other hand, $\mathrm{E}_{2} \beta$ stimulated the physical interaction between $\mathrm{ER} \alpha$ and $\mathrm{G} \alpha \mathrm{i}_{2 / 3}$ at the caveolae and activated the cGMP/protein kinase G type I $\beta$ (PKG-I $\beta$ ) pathway, thereby leading to the rapid phosphorylation of CSE and enhanced $\mathrm{H}_{2} \mathrm{~S}$ release [165]. Besides ER $\alpha$, ER46, an $N$-terminal truncated $E R \alpha$, can also form a complex with caveolin- 1 in the caveolae located in EC to induce rapid eNOS phosphorylation and endothelial NO release [166]. Additionally, the role of ER $\beta$ in caveolae has only been confirmed in non-EC colon cancer cells [123]. The stimulatory effects of $E_{2} \beta$ in receptor de-palmitoylation are opposite between ER $\alpha$ and ER $\beta$, in that de-palmitoylated ER $\alpha$ decreases the association with caveolin-1, whereas ER $\beta$ undergoes de-palmitoylation with receptor-caveolin- 1 association increased. Then, the ER $\beta$-caveolin- 1 complex 
further activates $\mathrm{p}_{38}{ }^{\mathrm{MAPK}}$ rather than Akt and ERK $\frac{1}{2}[123,167]$. Nonetheless, our recent study in UAEC showed that $E R \beta$ is not localized in the caveolar subcellular microdomain [93], suggesting that ER $\beta$ may mediate the nongenomic estrogenic effects in a caveolin-1-independent manner. Interestingly, ER can be the direct targets for phosphorylation by protein kinases like MAPK, suggesting that the nongenomic estrogen signaling mediated through ER can, in turn, regulate ER itself via a feed-forward mechanism [168].

\subsection{GPER-Mediated Nongenomic Effects in Uterine Vascular System}

In addition to the classical ERs $[169,170]$, some evidence has suggested that the effects of estrogen might be mediated by the transmembrane G-protein-coupled estrogen receptor (GPER). Coupled with the NO-cGMP signal pathway, GPER also appears to play a significant role in pregnancy-augmented vasodilatory effects in rat uterine arteries [108]. Because GPER is expressed in a vascular tone that responds to estrogen $[106,171]$, and because of the antihypertensive response from local alterations in the renin-angiotensin system, a great deal of studies focuses on the participation of GPER in estrogen-mediated actions. Notably, GPER was found to activate acute signaling pathways including cAMP accumulation in vascular SMC as a vasorelaxant action [172]. In endometrial cancer cells, GPER was also shown to mediate estrogen signaling on the activation of PI3K/Akt and ERK $\frac{1}{2}$ pathways $[173,174]$. Since GPER could bind the ligands overlapping with ER $\alpha$ and ER $\beta$, GPER-specific agonist G-1 [114] and the GPER-selective antagonist G-15 [116] were identified to unravel the functional roles of GPER, which shared a tetrahydro-3H-cyclopenta-[c]quinoline scaffold domain and showed an extremely high selectivity for GPER vs. ER $\alpha$ and ER $\beta$. For instance, G-1 can mimic the cardioprotective effects of $E_{2} \beta$ in rats [175], and promotes the pregnancy-associated vasodilatory effects of estrogens in rat UA, which can be blocked by G-15 [108]. Like estrogens, G-1 can also activate ERK $\frac{1}{2}$ signaling in uterine leiomyoma and myometrial SMC; this stimulation was further inhibited by the MEK inhibitor PD98059 in myometrium SMC [176]. In vitro, $\mathrm{E}_{2} \beta$-induced GPER activation mediates estrogen-induced cell proliferation [174]. However, in GPER knockout mice, it is shown that GPER only plays a minimal role in mediating estrogen-induced uterine proliferation and hypertrophy $[105,110-112]$. Thus, in the uterus, GPER works together with the classical ERs to integrally regulate uterine physiological responses to estrogens.

Classical ERs and GPER proteins are expressed in numerous organ vasculature systems of the body tissues. As predicted, the crosstalk, coupled with multiple estrogen receptors, involve various pathways and notably change the final biological outcome. Apart from the direct mediation of estrogenic signal transduction at the cellular level, membrane-localized GPER also communicates with ER $\alpha$ at the membrane to bind with $E_{2} \beta$ and form a complex [177]. The ability of $E_{2} \beta$ to stimulate MAPK pathways via the interaction between ER $\alpha$ and GPER has been reported in endometrial cancer cells [174]. As a truncated form of $\mathrm{ER} \alpha, \mathrm{ER} \alpha 46$ also interacts with $\mathrm{ER} \alpha$ co-located in endothelial cell membranes and appears to be more effective in the modulation of nongenomic pathways, like enhancing eNOS phosphorylation, than ER $\alpha$ alone [52]. In vascular cells (e.g., EC [178] and SMC [155]) and non-vascular cells (e.g., uterine epithelial cells [179]), GPER can, in some cases, antagonize the effects of classical ERs. Nonetheless, $E_{2} \beta$ failed to specifically bind, and did not activate, cAMP, ERK $\frac{1}{2}$ or PI3K, or stimulate gene transcription in EC from a combination of ER $\alpha$-ER $\beta$ knockout mice [128]. Thus, it remains to be determined whether GPER can act independently of ER to mediate rapid estrogen signaling responses. $\mathrm{E}_{2} \beta$ could also activate calcium immobilization and PI3K/Akt signaling through the co-localization of endogenous ER $\alpha$ and endoplasmic reticulum GPER [97]. However, the mechanisms of recruitment of membrane-localized ER to the endoplasmic reticulum-localized GPER and the respective signal transduction are still less understood.

\subsection{ER-Independent Estrogen Signaling and Estrogen-Independent ER Activation in UA}

In some cells, estrogens can also mediate cell physiology independent of estrogen receptors. In the uterus of OVX mice, Richards et al. found that $\mathrm{E}_{2} \beta$ treatment can directly enhance the tyrosine 
phosphorylation of insulin-like growth factor-1 receptor (IGF-1R), insulin receptor substrate 1 (IRS-1) and consequent PI3K signaling via the formation of an IGF-1R/IRS-1/PI3K complex $[180,181] . E_{2} \beta$ can also activate the epidermal growth factor receptor (EGFR) via the signaling of the lipid kinase sphingosine kinase-1 in breast cancer cells [182]. A great deal of studies also provided molecular evidence that the activation of receptor tyrosine kinases (RTK) (e.g., IGF-1R [126] and EGFR [127]) can trigger downstream MAPK and PI3K/Akt cascades, thereby indirectly activating ERs via the phosphorylation of Serine or Tyrosine residues [183-185].

Estrogen-independent ER activation has also been shown in vascular cells. Unliganded ER $\alpha$ inhibits EC proliferation but stimulates SM cell proliferation and activates the respective gene expression; this pattern is reversed in the presence of $E_{2} \beta$ [186]. ERs can also be activated in the absence of estrogens by growth factor receptor signaling coupled with the tyrosine kinase receptors of EGF and IGF [187]. In addition, fetal bovine serum (FBS) and EGF are able to activate $E R \alpha$, in the absence of $E_{2} \beta$, via a MAPK-independent pathway in vascular cells [188]. These studies suggested that the specific residues from ER itself or from other receptor ligands may be triggered in the absence of estrogens. Interestingly, the non-estrogen ligand-activated ER has been found to couple with signaling pathways different to those from the estrogen-activated ones, providing a hint that the effects of estrogens can determine ER-mediated intracellular mechanisms $[189,190]$. Whether these ligand-independent pathways for ER signaling pathways are involved in uterine hemodynamics in pregnancy is yet to be determined.

\subsection{Posttranslational and Epigenetic Modification of ER Actions}

Different types of posttranslational modifications, including phosphorylation, acetylation, sumoylation, and ubiquitination, etc., can directly regulate the stability and functions of ERs. As a nuclear transcription factor, modified ER transactivation will affect target gene expression [191]. For example, $E_{2} \beta$ enhances ER ubiquitination through degradation via the ubiquitin pathway in rat uteri [192]. Thus, in addition to the direct ER-regulated gene transcription, these posttranslational modifications may facilitate the transcriptional roles of ER in estrogenic responses in the vasculature. The direct p300-induced acetylation of ER $\alpha$ attenuates ligand-dependent transcription [193]. A conserved acetylation motif was identified in hinged region among mammalian species [194]; local site mutation results in increased cellular proliferation at sub-physiological levels of estrogens [195]. In addition, direct ligand-mediated sumoylation in $E R \alpha$ via the sumoylation site in its hinge region can regulate its transactivation function [191]. Sumoylation represses ER $\beta$-mediated transcriptional activity, while preventing ER $\beta$ from ubiquitous degradation by competing with ubiquitin at the same phosphorylated sumoylation site. This mechanism is connected to the GSK3 $\beta$-activated extension in response to the estrogens that act as sumoylation enhancers [196]. Although they are not the focus of this review, many other post-translational modifications, including phosphorylation, membrane targeting via palmitoylation, and interaction with caveolin-1, etc., have been reported to regulate ER function. However, the roles of these posttranslational mechanisms in mediating estrogen-induced uterine hemodynamics are yet to be explored.

In uterine endometrial cancer, abnormal methylation inactivates the ER gene and leads to subsequent hormone resistance [197]. Thus, ER-mediated gene expression may be also subject to epigenetic regulation in uterine vascular cells. Estrogens can also regulate microRNA (miRNA) expression, indicating that epidemic mechanisms for ER signaling may occur at the miRNA level. For example, $E_{2} \beta$ treatment upregulates miR-155, miR-429, and miR-451 and downregulates miR-181b and miR-204 in OVX mouse uteri [198]. In immature mice, $\mathrm{E}_{2} \beta$ treatment is able to regulate miR-451, miR-155, miR-335-5p and miR-365 expression [199], suggesting that miRNAs can be potential biomarkers for estrogen responses in utero. Notably, most studies on the estrogen-induced ER-dependent miRNAs in uterine tissues have been identified from malignant carcinoma and primary cultured cells isolated from the umbilical cord, which are summarized and listed in Table 1. miRNA-mediated epigenetic mechanisms for regulating ligand-dependent ER signaling have gained more attention lately in the reproductive system [200]. For example, during pregnancy and labor, 
the miR-199a/214 cluster was found to mediate the opposing effects of estrogen and progesterone on uterine contractility [201]. miR-203 could mediate ER-regulated gene expression and physiological processes including cell proliferation and migration in rat uteri, as well as the etiology of endometrial carcinoma [202]. As summarized in Table 2, it is now clear that miRNAs are implicated in the normal uterine tissues, including its vasculature system, as well as in the malignant phenotype. In the UA, miR-210 plays an opposite role in uterine vasodilation during pregnancy by inhibiting large conductance $\mathrm{Ca}^{2+}$-activated potassium channels $\left(\mathrm{BK}_{\mathrm{Ca}}\right)$ channel-mediated relaxation and increasing pressure-dependent myogenic tone [203].

Table 1. Uterine miRNAs whose expression is regulated by estradiol- $17 \beta\left(\mathrm{E}_{2} \beta\right)$.

\begin{tabular}{|c|c|c|c|}
\hline miRNA & Regulation & Tissue/Cell & References \\
\hline $\operatorname{miR}-451$ & $\uparrow$ & Mouse uterus & [199] \\
\hline $\begin{array}{l}\operatorname{miR}-429 \\
\operatorname{miR}-155\end{array}$ & $\uparrow$ & Mouse uterus & [198] \\
\hline $\begin{array}{l}\operatorname{miR}-181 b \\
\operatorname{miR}-204\end{array}$ & $\downarrow$ & Mouse uterus & [198] \\
\hline $\begin{array}{l}\text { miR-21 } \\
\text { miR-20a }\end{array}$ & $\downarrow$ & $\begin{array}{l}\text { Human endometrial } \\
\text { glandular epithelial cells }\end{array}$ & [204] \\
\hline $\begin{array}{l}\operatorname{miR}-21 \\
\text { miR-26a }\end{array}$ & $\downarrow$ & Human leiomyoma SMC & [204] \\
\hline $\begin{array}{l}\text { miR-30b } \\
\text { miR-487a } \\
\text { miR-4710 } \\
\text { miR-501-3p }\end{array}$ & $\uparrow$ & Human UVEC & [205] \\
\hline $\begin{array}{l}\text { miR-378h } \\
\text { miR-1244 }\end{array}$ & $\downarrow$ & Human UVEC & [205] \\
\hline
\end{tabular}

$\uparrow$, upregulation; $\downarrow$, downregulated.

Currently, only a limited number of studies have reported on the epigenetic regulation of uterine hemodynamics during pregnancy. However, a critical role of methylation mechanisms in estrogen-induced uterine vasodilation has been demonstrated recently. In ovine UA ex vivo, Dasgupta et al. first reported that hypoxia induces the pregnancy-repressed methylation levels in CpG islands in SP-1-binding sites in the ER $\alpha$ promoter, thereby abrogating pregnancy-induced SP-1 binding to the ER $\alpha$ promoter [206]. This finding, in ovine UA, was followed up by Chen and colleagues, who found that hypoxia can decrease ER $\alpha$ expression, accompanied by increases in the methylation levels in the SP-1-binding site in the ER $\alpha$ promoter; the DNA methylation inhibitor 5-Aza-2'-deoxycytidin can restore the hypoxia-repressed ER $\alpha$ expression as well as the levels of SP-1 binding to the ER $\alpha$ promoter [207]. Pregnancy-triggered $\mathrm{E}_{2} \beta$ - or progesterone-induced ER $\alpha$ expression can also be inhibited by hypoxia via enhanced methylation that curbs SP- 1 binding to the ER $\alpha$ promoter. In this way, chronic hypoxia represses steroid hormone-upregulated $\mathrm{BK}_{\mathrm{Ca}}$ channel activity in ovine UASMC, indicating a critical role of DNA methylation-affected $\mathrm{ER} \alpha$ in relaxing $\mathrm{UA} S \mathrm{SM}$ via $\mathrm{BK}_{\mathrm{Ca}}$ channels. Moreover, similar epigenetic mechanisms have also been reported in the ovine UA model, showing that hypoxia can abrogate pregnancy-induced demethylation in the SP-1-binding site as well as SP-1- and $\mathrm{ER} \alpha$-binding levels to the promoter of the $\mathrm{BK}_{\mathrm{Ca}}$ channel assembly-pore forming auxiliary $\beta 1$ subunit encoding gene KCNMB1 [208]. In addition to direct regulation by environmental factors (e.g., hypoxia) or physiological states (e.g., pregnancy) of the CpG methylation level, the oxygen level and pregnancy-triggered steroid hormones can also indirectly alter the CpG methylation level by regulating DNA demethylation enzyme ten-eleven translocation (TET) methylcytosine dioxygenases in UA; $E_{2} \beta$ - or progesterone-induced TET1 expression can subsequently downregulate the methylation 
level in the SP-1-binding site in the KCNMB1 promoter; TET1 enzymatic activity inhibition by its competitive inhibitor, fumarate, can restore the $\mathrm{E}_{2} \beta$ - or progesterone-stimulated $\mathrm{BK}_{\mathrm{Ca}}$ activity in UASMC [209]. These studies have demonstrated the role of DNA methylation in estrogen-induced uterine relaxation in the ovine UA.

Table 2. Uterine miRNAs, their proposed function and transcriptional targets.

\begin{tabular}{|c|c|c|c|c|}
\hline miRNA & Tissue/Cell & Functions & Targets & References \\
\hline $\begin{array}{l}\text { miR-199a } \\
\text { miR-214 }\end{array}$ & $\begin{array}{l}\text { human telomerase reverse } \\
\text { transcriptase-immortalized } \\
\text { human myometrial } \\
\text { (hTERT-HM) cell line }\end{array}$ & Contractility & Cyclooxygenase-2 (COX-2) & [201] \\
\hline miR-203 & $\begin{array}{c}\text { Rat uterus } \\
\text { Endometrial carcinoma }\end{array}$ & $\begin{array}{l}\text { Proliferation } \\
\text { Migration }\end{array}$ & $\begin{array}{c}\text { Zinc finger and BTB domain } \\
\text { containing } 20 \text { (Zbtb20), } \\
\text { Alkaline Ceramidase } 2 \\
\text { (Acer2) }\end{array}$ & [202] \\
\hline miR-451 & $\begin{array}{c}\text { Human endometriotic } \\
\text { lesions }\end{array}$ & Migration & $\begin{array}{l}\text { Macrophage Migration } \\
\text { Inhibitory Factor (MIF) }\end{array}$ & [210] \\
\hline miR-218-5p & $\begin{array}{l}\text { Extravillous cytotrophoblast } \\
\text { (EVT) }\end{array}$ & $\begin{array}{c}\text { Trophoblast } \\
\text { differentiation } \\
\text { Vessel remodeling }\end{array}$ & $\begin{array}{l}\text { Transforming growth factor } \\
\qquad \beta 2 \text { (TGF } \beta 2)\end{array}$ & [211] \\
\hline miR-204 & $\begin{array}{c}\text { Human endometrial } \\
\text { cancer-1 (HEC-1A) cell line }\end{array}$ & $\begin{array}{l}\text { Migration } \\
\text { Invasion }\end{array}$ & Forkhead box C 1 (FOXC1) & [212] \\
\hline miR-365 & Trophoblasts & $\begin{array}{l}\text { Cell cycle } \\
\text { Apoptosis }\end{array}$ & $\begin{array}{l}\text { Mouse double minute } 2 \\
\text { (MDM2), p53 }\end{array}$ & [213] \\
\hline $\operatorname{miR}-376 c$ & Trophoblasts & $\begin{array}{l}\text { Proliferation } \\
\text { Invasion }\end{array}$ & TGF $\beta 2$ & [214] \\
\hline $\begin{array}{l}\text { miR-17 } \\
\text { miR-20a } \\
\text { miR-20b }\end{array}$ & Placenta & Angiogenesis & $\begin{array}{c}\text { Ephrin-B2 } \\
\text { Ephrin type-B receptor } 4 \\
\text { (EPHB4) }\end{array}$ & [215] \\
\hline miR-210 & Ovine UA & Relaxation & $\begin{array}{l}\text { Tet methylcytosine } \\
\text { dioxygenase } 1 \text { (TET1) }\end{array}$ & [203] \\
\hline
\end{tabular}

\section{Gasotransmitters in Estrogen-Induced Uterine Vasodilation in Pregnancy}

As early as the late 1970s, RNA and protein synthesis inhibitors were used to determine if de novo protein synthesis is involved in estrogen-induced uterine vasodilation because UtBF rapidly increases at 5-15 min following a single bolus injection in various animals, including rabbits [216], guinea pigs [217], sows [218] and ewes [219]. Early studies showed that the unilateral infusion of cycloheximide significantly inhibits $\mathrm{E}_{2} \beta$-induced UtBF elevation during 90-min infusion, while the contralateral $\mathrm{E}_{2} \beta$-induced UtBF is unaffected; this inhibition lasts for more than $30 \mathrm{~min}$ after the removal of the cycloheximide infusion [24]. Follow-up studies have also shown that cycloheximide inhibited the estrogen-induced increase in uterine cGMP secretion in a dose-dependent manner, showing a $50 \%$ decrease in UtBF and a $\sim 90 \%$ reduction in cGMP section at the time of the maximum UBF pattern [220]. These studies suggest that de novo protein synthesis is required for estrogen-induced uterine vasodilation.

The local infusion of ICI 180, 782 also dose-dependently inhibits estrogen-induced and pregnancy-associated uterine vasodilation [25]. In keeping with the rapid initiation of the rise in UtBF following estrogen administration [24,25], the mechanisms underlying the uterine vasodilatory effects of estrogens are expected to be mediated by ER-dependent and -independent rapid genomic and nongenomic pathways, as summarized in Figure 2. However, how each pathway is activated by estrogens and their relative significance is not fully elucidated. Nonetheless, there is ample evidence that estrogen-induced uterine vasodilation is mediated largely by the ER-dependent augmentation of the orchestrated production of vasodilators locally by the UA, including the family of "gasotransmitters", 
i.e., $\mathrm{NO}, \mathrm{CO}$, and $\mathrm{H}_{2} \mathrm{~S}$ (Figure 3). These gaseous signaling molecules are produced by EC and SMC, which coordinatively relax uterine arteries by activating cGMP-dependent pathways and potassium channels $\left(\mathrm{K}^{+}\right)$including $\mathrm{BK}_{\mathrm{Ca}}$ and voltage-gated $\mathrm{K}^{+}\left(\mathrm{K}_{\mathrm{v}}\right)$ channels, etc.

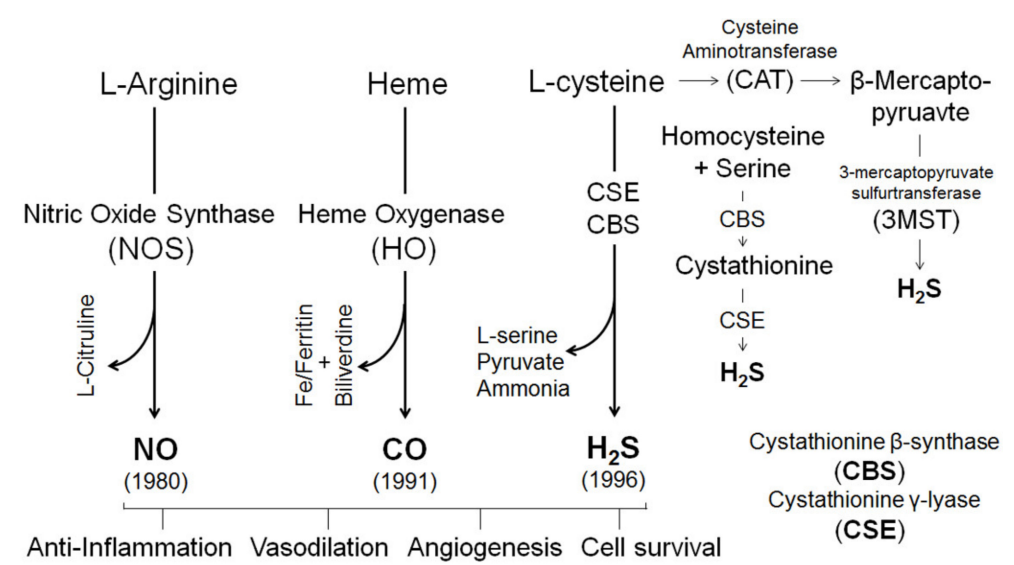

Figure 3. Gasotransmitters: biosynthesis and function. Nitric oxide (NO), carbon monoxide (CO), and hydrogen sulfide $\left(\mathrm{H}_{2} \mathrm{~S}\right)$ were identified as gasotransmitters in 1980, 1991 and 1996, respectively. NO is synthesized by a family of NO synthases (eNOS, nNOS or iNOS) via converting L-arginine to L-citrulline. $\mathrm{CO}$ is synthesized by heme oxygenases (HO-1 or HO-2) by oxidizing heme to produce $\mathrm{CO}$ along with biliverdin and iron/ferritin. $\mathrm{H}_{2} \mathrm{~S}$ is mainly synthesized by cystathionine $\beta$-synthase (CBS) or cystathionine- $\gamma$-lyase (CSE) by converting L-Cysteine to L-Serine or Pyruvate and $\mathrm{NH}_{4}{ }^{+}$; $\mathrm{H}_{2} \mathrm{~S}$ can also be produced by condensation of homocysteine and serine into cystathionine by CBS and by CSE to produce $\mathrm{H}_{2} \mathrm{~S}$. In addition, cysteine aminotransferase (CAT) and 3-mercaptopyrivate sulfurtransferase (3MST) can also catalyze the biosynthesis of $\mathrm{H}_{2} \mathrm{~S}$ from L-Cysteine via the intermediate product as $\beta$-Mercapto-pyruvate. The gasotransmitters $\mathrm{NO}, \mathrm{CO}$ and $\mathrm{H}_{2} \mathrm{~S}$ act to regulate cell survival, anti-inflammation, cardioprotective angiogenesis and vasodilation.

\subsection{Nitric Oxide}

NO is the most studied gaseous molecule of gasotransmitters that plays a role in a variety of biological processes in almost all types of organisms, ranging from single-cell organisms, to bacteria and plants, as well as animal and human cells. In the 1990s, the biology of NO exploded with the discovery that $\mathrm{NO}$ is an endothelium-derived relaxing factor (EDRF), which was discovered with the use of organ bath studies [221,222]. NO is biosynthesized endogenously via the conversion of $\mathrm{L}$-arginine to L-citrulline in the presence of molecular $\mathrm{O}_{2}$ and nicotinamide adenine dinucleotide phosphate (NADPH) by a family of NO synthase (NOS) enzymes, including the $\mathrm{Ca}^{2+}$-dependent endothelial NOS (eNOS/NOS3) and neuronal NOS (nNOS/NOS2), and the $\mathrm{Ca}^{2+}$-independent inducible NOS (iNOS/NOS1) [223]. NO was the first gas molecule that was discovered to act as a chemical messenger in the body; endogenous $\mathrm{NO}$, in a physiological concentration range, is essential for the normal functions of the brain, arteries, immune system, liver, pancreas, uterus, nerves and lungs, to name a few. These diverse functions have resulted in NO being named the Molecule of Year in 1992 [224]. In 1998, three scientists, Robert Furchgott, Louis Ignarro, and Ferid Murad, were awarded the Nobel Prize in Physiology or Medicine "for their discoveries concerning NO as a signaling molecule in the cardiovascular system" [225].

$\mathrm{NO}$ is highly reactive and can diffuse freely across membranes, and hence is ideal for a transient paracrine (between adjacent cells) and autocrine (within the cell producing it) signaling molecule. NO has a lifetime less than 10 seconds and the diffusion gradients of $\mathrm{NO}$ are limited by scavenging reactions involving hemoglobin [226], myoglobin [227] and other radicals [228]. However, NO can be stabilized in the blood and tissue by oxidation to nitrate $\left(\mathrm{NO}_{2}{ }^{-}\right)$and nitrite $\left(\mathrm{NO}_{3}{ }^{-}\right)$, which can be transported to cells far away from where they were produced to function as endocrine molecules. $\mathrm{NO}$ also reacts with free thiols (-SH) in reactive cystines in proteins or metals to form nitrosothiols 
(-SNO) that function as NO reservoirs [229]. This reaction is called S-nitrosylation and it is reversible; thus, nitrosothiols have the potential to be converted back to NO under physiological and pathological conditions. Moreover, $\mathrm{NO}$ can react with superoxide $\left(\mathrm{O}_{2}^{-}\right)$to form peroxynitrite $\left(\mathrm{ONOO}^{-}\right)$under oxidative stress conditions [230]; peroxynitrite is highly reactive with tyrosine residues, a reaction called protein $S$-nitration that normally results in the damage/deactivation of protein function [231].

In blood vessels, NO is mainly biosynthesized by eNOS, which is exclusively expressed in the EC (inner lining); endothelium-derived NO diffuses into the surrounding SMC, where it activates the soluble guanylyl cyclase (sGC)-cGMP pathway to relax the blood vessels, thus resulting in vasodilation and an increasing blood flow [232]. One of the main intracellular enzymatic targets of NO is sGC; in the presence of iron, the binding of $\mathrm{NO}$ to the heme region of sGC leads to the activation of the enzyme to produce the second messenger cGMP [233]. The major cellular targets of cGMP are cGMP-dependent protein kinases (PKGs), cGMP-gated cation channels, and cyclic nucleotide phosphodiesterases (PDEs), which break down cGMP [234]. In light of the diverse physiological functions of NO in organs throughout the human body, the targeting of some or all of these steps of NO signaling pathways has been a focus of development for various diseases. The most cited drug is sildenafil (Viagra), a common example of a drug that modulates a distal component of the NO pathway. Viagra does not stimulate the biosynthesis of NO, but enhances downstream signaling by shielding CGMP from degradation by cGMP-dependent phosphodiesterase type 5 inhibitor (PDE5) in the rat uterine arteries, thus promoting an increase in UtBF $[235,236]$.

Magness and colleagues were the first to report that eNOS, but not nNOS, is expressed in the intact (but not the denuded) ovine UA and that pregnancy greatly stimulates eNOS expression ex vivo in the UA endothelium and in vitro in ovine UAEC [237]. This was supported by their subsequent study, demonstrating that acute $E_{2} \beta$ treatment can stimulate eNOS expression in the ovine UA endothelium and that chronic $\mathrm{E}_{2} \beta$ perfusion is able to continuously increase eNOS expression in the UA endothelium [238]. Weiner and colleagues first reported, in guinea pigs, that pregnancy significantly increases $\mathrm{Ca}^{2+}$-dependent (but not $\mathrm{Ca}^{2+}$-independent) NOS activity (measured by ${ }^{3} \mathrm{H}$-Arginine to ${ }^{3} \mathrm{H}$-Citrulline conversion assay) in a variety of organs, including a twofold rise in heart, kidney, skeletal muscle, esophagus, and cerebellum, with the greatest being up to a fourfold rise in whole-UA homogenates, compared to nonpregnant controls [239]. Treatment with $\mathrm{E}_{2} \beta$ (but not progesterone) also increases calcium-dependent NOS activity in these tissues, although they did not examine the effects of $E_{2} \beta$ on UA. Consistently, pregnancy and $E_{2} \beta$ both stimulate mRNA expression of eNOS and nNOS, but not iNOS, in the skeletal muscle. Moreover, the pregnancy-associated upregulation of $\mathrm{Ca}^{2+}$-dependent NOS activity is mediated by endogenous estrogens via classical ER, since it is blocked by the ER antagonist tamoxifen [239]. Subsequently, Magness et al. demonstrated similar results in ovine UA, showing that chelating $\mathrm{Ca}^{2+}$ with ethylene glycol-bis( $\beta$-aminoethyl ether)- $N, N, N^{\prime}, N^{\prime}$-tetraacetic acid (EGTA) downregulates NOS activity in ovine UA [237,240]. In the human model, Nelson and colleagues also showed that pregnancy-enhanced eNOS and nNOS expression accounts for the elevated $\mathrm{Ca}^{2+}$-dependent NOS activity in pregnancy [241]. Notably, baseline $\mathrm{Ca}^{2+}$-independent NOS activity was significantly higher in the pregnant than in nonpregnant UA, and a considerable amount of pregnancy-induced NOS activity is independent of $\mathrm{Ca}^{2+}$ modulation [241]. These findings in human UA were remarkably different to the counterpart study in guinea pig skeletal muscles.

Many groups have since examined the effects of pregnancy and estrogens on UA NOS-NO systems in many species including mice [242], rats [243], sheep [32,35,90], nonhuman primates [244], and women [245]. These studies have convincingly shown that (1) exogenous estrogens stimulate UA eNOS activation and NO production $[90,238]$ and (2) the UA eNOS-NO system is significantly augmented during pregnancy and the follicular phase of the ovarian cycle [246,247], positively correlating with the elevated endogenous estrogens seen in these physiological states [241]. Moreover, with highly specific antibodies against each of the NOS isoforms becoming available, immunological studies, including Western blot analyses of mechanically purified endothelial proteins of ovine UA endothelium and SM and immunohistochemistry [238] or immunofluorescence microscopy [248], have concluded that 
pregnancy and estrogens specifically upregulate eNOS protein expression in the EC, but not SMC, in vivo in all species examined including women [241]. Consistently, some of these studies also have shown that blood and UA tissue levels of NO (measured by nitrite/nitrate) and cGMP are augmented during pregnancy and are also stimulated by estrogens [237,240,249].

Rosenfeld and colleagues performed a classical study using the OVX sheep model to determine the role of the local NOS-NO system in estrogen-induced uterine vasodilation. They reported that local UA infusion of the NOS inhibitor N(w)-nitro-L-arginine methyl ester (L-NAME) dose-dependently inhibits the estrogen-induced maximal rise in UtBF in nonpregnant OVX ewes [35]. This study has established a critical role of local NO production in estrogen-induced uterine vasodilation, which is consistent with studies in nonpregnant ewes [32] and pregnant ewes [35], and in intact ewes in the follicular phase triggered by progesterone [25]. However, L-NAME can only inhibit at most $\sim 79 \%$ of the estrogen-induced UtBF response in all these studies, suggesting that mechanisms in addition to $\mathrm{NO}$ exist to mediate estrogen-induced uterine vasodilation.

These physiological and pharmacological studies have promoted mechanistic studies for dissecting the cellular and molecular mechanisms controlling UA production of NO and how NO regulates uterine vascular functions further. As ex vivo studies have conclusively shown that local UA production is exclusively synthesized in the EC during pregnancy and upon estrogen stimulation and various other physiological regulators of UA vasodilation, such as vascular endothelial growth factor [250] and angiotensin-II [251], the Bird and Magness groups first developed novel primary culture models of UAEC from the main uterine arteries of nonpregnant and late ( 130-140 days in ovine gestation, equivalent to the third trimester in human pregnancy) pregnant ewes [161] to study how UA local NO is synthesized during pregnancy and upon stimulation. Moreover, akin to nearly all primary EC culture models, the limited number of primary ovine UAEC directly isolated from the uterine arteries must be passaged so that there are enough cells for experimental investigation. Fortunately, after four to five passages, nonpregnant and pregnant UAEC maintain their physiological pregnancy-specific differences in baseline expressions of key enzymes for cell signaling and vasodilator (NO and prostacyclin) production, as well as their pregnancy-dependent responses to vascular endothelial growth factor (VEGF) [161]. These features make the ovine UAEC culture model the best available for dissecting the molecular mechanisms for UA hemodynamic regulation in pregnancy. Numerous studies from the Bird and Magness groups have shown that growth factors (VEGF, fibroblast growth factor 2 (FGF-2), and EGF) and signaling via MAPK and PI3K/Akt pathways in UAEC are programmed to stimulate eNOS activation and NO production via intracellular $\mathrm{Ca}^{2+}$ mobilization and Serine ${ }^{1177}$ phosphorylation in pregnancy [161]. Their studies have greatly advanced the cellular molecular mechanisms regulating the pregnancy-dependent upregulation of the local EC production of NO. Detailed information of these mechanisms can be found in their reviews [252-254].

We were the first to report UA ER $\alpha, E R \beta$ mRNA and protein expression in EC and SMC in pregnant ovine UA ex vivo [39,71]; we also showed that ER $\alpha$ and ER $\beta$ are retained in UAEC cultures after up to five passages $[71,90,255]$, showing that the ovine UAEC model is indeed suited to study estrogen-induced uterine vasodilation in vitro. Like the ovine fetal pulmonary artery EC [256], we showed that treatment with physiological relevant concentrations (1-10 nM) of $E_{2} \beta$ rapidly phosphorylates Raf-1/ERK $\frac{1}{2}$ within 2-5 min in pregnant ovine UAEC in culture; this pathway mediates $\mathrm{E}_{2} \beta$-induced NO production by indirect eNOS Ser ${ }^{1177}$ phosphorylation via a rapid nongenomic pathway with $E R \alpha$ localized on the plasma membrane [90]. We did not find that $E_{2} \beta$ mobilizes intracellular $\mathrm{Ca}^{2+}$ or activates PI3K-Akt in ovine UAEC [90], both of which are essential for rapid eNOS activation and direct Ser ${ }^{1177}$ phosphorylation, as reported for UAEC [94] and other ECs [257]. Nonetheless, the classical ER-mediated rapid nongenomic regulation of NO production in UAEC seems to be mediated by $\mathrm{ER} \alpha$ because (1) $\mathrm{ER} \alpha$, but not $\mathrm{ER} \beta$, possesses binding domains to caveolin-1 [258]; (2) treatment with $E_{2} \beta$ promotes $E R \alpha$ membrane translocation to the caveolae [71,90]; and (3) rapid activation of eNOS involves the formation of a so-called steroid receptor fact action complex (SRFC) involving ER $\alpha$, eNOS, and the enzymes that activate eNOS, such as AKT and ERK $\frac{1}{2}$, in the caveolae [122]. 
The membrane-bound GPER also mediates rapid estrogenic actions to increase pregnancy-dependent uterine vasodilation in rats, which is largely endothelium/NO dependent [108]. GPER has been shown to be present in rat UAEC [108]. However, the underlying mechanisms by which GPER mediates rapid eNOS activation by estrogens in UAEC are not currently known.

Concomitantly with the continuous increases in endogenous estrogens, UtBF increases continuously during gestation, essentially keeping pace with the growth rate of the fetus [259]. Thus, the production of local vasodilators such as NO must be subjected to chronical upregulation during pregnancy and stimulation by estrogens via genomic nuclear action to upregulate the expression of eNOS, a scenario as described above during pregnancy $[237,260]$, the follicular phase of the ovarian cycle $[238,261]$ and long-term estrogen replacement therapy (ERT) in OVX animals [22,262], or even in post-menopausal women [263]. In vivo, ERT selectively stimulates UA endothelial eNOS expression, potentially via upregulating eNOS transcription [22]. The eNOS gene promoter contains functional half-palindromic EREs and $\mathrm{E}_{2} \beta$ stimulates $\mathrm{ER} \alpha$-dependent eNOS transcription in bovine pulmonary artery EC [264]. We reported that the activation of AP-1 may be important for UAEC eNOS transcription [265]. However, the specific roles of ER $\alpha$ and ER $\beta$ in the estrogen stimulation of eNOS transcription and expression in UAEC has not been determined. Nonetheless, our recent report has shown that treatment with PPT and DPN, similar to $E_{2} \beta$, for $24-48 \mathrm{~h}$, induces an increase in the stimulatory phosphorylation sites in ${ }^{\mathrm{Ser} 1177} \mathrm{eNOS}$ and ${ }^{\mathrm{Ser} 635} \mathrm{eNOS}$, a decrease in the inhibitory phosphorylation site ${ }^{\mathrm{Thr}} 495 \mathrm{eNOS}$, and an increase in total NO levels in ovine UAEC in vitro [94]. These findings suggest that the activation of both $E R \alpha$ and $E R \beta$ is involved in upregulating eNOS expression and activation to produce NO for mediating estrogen-induced uterine vasodilation in pregnancy.

Since estrogen treatment and pregnancy increases local UA production of both NO and cGMP, it is expected that the sGC-cGMP-PKG pathway is the major mechanism responsible for estrogen-induced uterine vasodilation in pregnancy. Indeed, myography studies have shown that the relaxation effects of pregnancy on pre-constricted UA rings are inhibited by the specific inhibitor of sGC [1-H-[1,2,4]oxadiazolo[4,3-a]quinoxalin-l-one (ODQ)] but recovered by the cGMP-hydrolysis enzyme PDE5 inhibitor sildenafil [236]. Since NO-induced activation of PKG directly phosphorylates $\mathrm{BK}_{\mathrm{Ca}}$ channels [266], which causes vascular SM relaxation [232], the local infusion of the $\mathrm{BK}_{\mathrm{Ca}}$ inhibitors tetraethylammonium chloride (TEA) and iberiotoxin (IBTX) can partially attenuate the estrogen-induced rise in UtBF in nonpregnant ewes and also inhibits baseline UtBF in pregnant ewes $[267,268]$. Overall, the available evidence shows a critical role of the sGC-cGMP-PKG-BK ${ }_{\mathrm{Ca}}$ pathway in estrogen-induced uterine vasodilation in normal pregnancy. In addition, other $\mathrm{K}^{+}$channels such as voltage-gated $\mathrm{K}^{+}(\mathrm{Kv})$ channels and small and medium conductance $\mathrm{K}^{+}$channels [67], may be involved in estrogen-induced uterine vasodilation in pregnancy; however, these $\mathrm{K}^{+}$channels seem to regulate uterine vasodilation under pathological conditions such as gestational diabetes [269].

NO is also involved in other uterine vascular changes adaptive to pregnancy such as UA remodeling [270]. We have shown that estrogens stimulate protein $S$-nitrosylation (SNO) in human umbilical cord vein EC (HUVEC) and ovine UAEC in vitro [255,271], in which ER $\alpha$ and ER $\beta$, respectively, play different cell-specific roles [255]. Estrogen stimulation of endothelial protein SNO has been confirmed in rat UA in vivo [272]. The increased S-nitrosothiols stimulated by estrogens could serve as a NO reservoir for long-term NO signaling when it is needed [273]. We have reported that eNOS-derived endogenous NO, upon stimulation with estrogens and VEGF, stimulates SNO of a specific reactive cysteine (Cys80) among the four cysteines (Cys39/80/139/147) in cofilin-1 in EC $[274,275]$. Cofilin-1 is a major actin-binding protein that regulates cytoskeleton remodeling during cell proliferation and differentiation [276]. SNO results in the increased severing activity of cofilin-1, thereby regulating cytoskeleton remodeling and migration in response to stimulation with estrogens and VEGF [274,275]. Thus, it is speculative that increased SNO proteins may play a role in UA remodeling upon estrogen stimulation during pregnancy [270,277]. 
Numerous studies have demonstrated that mitochondrion is a major cellular organelle that is directly affected by endogenous NO synthesized upon estrogen stimulation [278-280]. NO exposure greatly affects the biogenesis of mitochondrion and its respiration chain [281]. Indeed, our previous studies have shown that total levels of mitochondrial SNO proteins are significantly increased by treatment with $\mathrm{E}_{2} \beta$ to upregulate endogenous $\mathrm{NO}$ and by treatment with exogenous $\mathrm{NO}$ from $\mathrm{NO}$ donors in HUVEC. However, there are considerable differences (i.e., proteins and SNO levels) in the endogenous and exogenous NO-responsive endothelial SNO proteomes [282]. Interestingly, SNO of the mitochondrial protein is affected by locally synthesized $\mathrm{NO}$ since $\mathrm{E}_{2} \beta$-stimulated mitochondrial protein SNO in HUVEC is only enhanced by the overexpression of mitochondrion-targeting eNOS, but not by membrane-targeting eNOS [282], suggesting that estrogens affect mitochondrial SNO via local eNOS-synthesized NO.

\subsection{Carbon Monoxide}

$\mathrm{CO}$ is another biological gas that possesses similar physiological effects to NO in the vasculature. $\mathrm{CO}$ was initially regarded as a poisonous gas that is released with the formation of carboxyhemoglobin $(\mathrm{COHb})$ under hypoxic conditions [283]. Under hypoxic conditions, high $\mathrm{CO}$ concentrations cause hypoxemia by competitive binding to the oxygen-binding sites of hemoglobin to form $\mathrm{COHb}$, with an affinity approximately 245 times that of oxygen [284]. Thus, decreased concentrations of oxyhemoglobin $(\mathrm{OHb})$ are inevitable in $\mathrm{COHb}$-caused toxicity in hypoxemia [285]. In humans, prolonged or elevated CO exposure can cause a few acute clinical effects, including nausea, dizziness, and loss of consciousness. Symptoms of $\mathrm{CO}$ poisoning begin to appear at $20 \% \mathrm{COHb}$, while death occurs between 50 and $80 \%$ $\mathrm{COHb}[284]$.

In the 1950s, CO was found in the exhaled air in hospitalized patients [286]; however, this endogenously produced CO initially attracted little attention as an endogenous physiologic mediator until 1993, when Verma and colleagues identified a neurotransmitter function for endogenous CO in olfactory neurotransmission [287]. Subsequently, studies have shown that endogenously produced CO and low concentrations (e.g., $250 \mathrm{ppm}$ ) of exogenous $\mathrm{CO}$ possess various physiological functions, including a vascular role in regulating hepatic perfusion [288], anti-inflammation [289], anti-apoptosis [290,291], and the inhibition of vascular SMC proliferation [292], etc. Endogenous CO is produced physiologically via a single mechanism, the metabolism of heme to $\mathrm{CO}$, biliverdin, and free iron by heme oxygenase (HO) [293]. HO exists as at least two isoforms that are encoded by two distinct genes, HMOX1 and HMOX2. In humans, HO-1 is an inducible, low molecular weight heat shock protein-32 [294], whose expression is readily inducible by innumerable stimuli such as cAMP [295] and hypoxia [296]. On the contrary, HO-2 is a $36-\mathrm{kD}$ protein that tends to be expressed constitutively and appears to be mainly regulated by steroids $[297,298]$. The highest levels of HO-2 are found in the brain, accounting for the majority of the neurotransmission functions of CO in the brain [298].

Several studies have established the role of the HO-CO system in pregnancy. Acevedo and colleagues have shown that the expression levels of HO-1 and HO-2 proteins are more than 10-fold greater $(p<0.001)$ in pregnant (regardless in labor or not in labor) than in nonpregnant human myometrium, which are upregulated by progesterone but not estrogens. Functional analysis also showed that HO-1 derived CO inhibits human myometrial contractility [299]. Follow-up studies have shown that the HO-1/CO system appears to be important in prenatal and postnatal development via regulating angiogenesis and immune hemostasis at the maternal-fetal interface. For mice lacking Hmox1, this is embryonically lethal [300], whereas a partial maternal Hmox1 deficiency $\left(H \operatorname{mox} 1^{+/-}\right)$ results in malformation of the maternal-fetal interface due to insufficient spiral artery remodeling and uterine natural killer (uNK) cell differentiation and maturation [301,302].

HO-1 is widely expressed in various tissues in the body and is highly inducible by oxidative stress, ultraviolet (UV) light, heavy metals and inflammation [303]; HO-2 has been found in vascular EC but is unresponsive to inducers of HO-1 [304]. Both HO-1 and HO-2 are expressed in vascular EC and SMC [304-306], and the HO-catalyzed formation of CO has been documented 
in blood vessels [307], suggesting that the vasodilatory roles of them might exist in the vasculature. Endogenously produced $\mathrm{CO}$ and exogenous $\mathrm{CO}$ can cause the endothelium-independent dilation of arteries and arterioles [294,308,309]. HO-1-produced endogenous CO appears to provide a tonic vasodepressor effect via the inhibition of an autonomic pressor mechanism [310]. In pulmonary arteries, endothelium-derived $\mathrm{CO}$ mediates acetylcholine (ACH)-induced vasorelaxation [311]. HO-2 protein is also highly expressed in large and small blood vessels and in adjacent astrocytes in the brain [312]. CO is a potent cerebral vessel dilator, as topically applied CO potently dilates piglet pial arterioles and the maximal response can be achieved by as low as $1 \mathrm{nM} \mathrm{CO}[313,314]$. The vasodilatory effect of $\mathrm{CO}$ is mediated by the activation of sGC to generate cGMP in autocrine and paracrine fashions [294,308,309,311]. In vitro, CO can hyperpolarize vascular SM via modification of a histidine residue on the external membrane side of the $\mathrm{BK}_{\mathrm{Ca}}$ channels $[309,315]$. In vivo, CO-induced cerebrovascular dilation was abolished by treatment with TEA and IBTX [313,314], suggesting that the vasodilatory effects of $\mathrm{CO}$ are mainly mediated by activating the sGC-cGMP-PKG-BK $\mathrm{Ca}_{\mathrm{a}}$ pathway.

Pregnancy upregulates HO-1 and HO-2 expression in human myometrial uterine blood vessels [299]. Although studies using partial Hmox1-deficient mouse models have shown that the HO-1/CO system regulates uterine spiral artery remodeling [301], there is no direct evidence regarding the role of the $\mathrm{HO}-\mathrm{CO}$ system in estrogen-induced UA vasodilation during pregnancy. Nonetheless, physiologically relevant concentrations $(0.1 \mathrm{nM})$ of $\mathrm{E}_{2} \beta$ stimulate the ER-dependent upregulation of HO-2 mRNA/protein expression and CO production and elevate intracellular cGMP concentrations in HUVEC and HUAEC in vitro [33]. Moreover, equol (a non-steroid estrogen) can also stimulate ER $\beta$ (but not ER $\alpha$ )-dependent HO-1 expression via the PI3K/Akt-nuclear respiratory factor (Nrf) pathway in HUVEC [316]. These studies suggest the HO-1/CO system may play a role in uterine hemodynamics in response to estrogens in pregnancy. Moreover, low respiratory and serum $\mathrm{CO}$ are associated with hypertension in pregnancy and exhaled $\mathrm{CO}$ is inversely correlated with gestational hypertension in women [317], also providing indirect evidence for the role of the $\mathrm{HO} / \mathrm{CO}$ system in uterine vascular adaptation to pregnancy.

\subsection{Hydrogen Sulfide}

$\mathrm{H}_{2} \mathrm{~S}$ has been long recognized as a sewer gas with a characteristic foul odor of rotten eggs [318]. It was not until 1996 that Abe and Kimura first reported that endogenous $\mathrm{H}_{2} \mathrm{~S}$ is produced by $\mathrm{CBS}$ in the hippocampus and that physiological concentrations of $\mathrm{H}_{2} \mathrm{~S}$ selectively enhance $N$-methyl-D-aspartate (NMDA) receptor-mediated responses and facilitate the induction of long-term hippocampal potentiation, establishing that endogenous $\mathrm{H}_{2} \mathrm{~S}$ functions as a neuromodulator in the brain [319]. Since then, research into $\mathrm{H}_{2} \mathrm{~S}$ biology and medicine has flourished and demonstrated a plethora of biological, physiological, and pathological functions of $\mathrm{H}_{2} \mathrm{~S}$ in the neuronal, immune, cardiovascular, endocrine and digestive systems, and cancers [320]. Due to similar biochemical properties and functions, as well as mechanisms of action, $\mathrm{H}_{2} \mathrm{~S}$ has now been widely accepted as the third "gasotransmitter" after $\mathrm{NO}$ and $\mathrm{CO}$ [321].

Endogenous $\mathrm{H}_{2} \mathrm{~S}$ is mainly synthesized from L-cysteine by the two pyridoxal-5'-phosphatedependent enzymes CBS and CSE of the trans-sulfuration pathway [322,323]. CBS catalyzes the transfer from serine and cysteine to cystathionine, during which $\mathrm{H}_{2} \mathrm{~S}$ is produced as a product. CSE synthesizes $\mathrm{H}_{2} \mathrm{~S}$ through three pathways, including (1) the $\beta$-elimination of cysteine to pyruvate, $\mathrm{H}_{2} \mathrm{~S}$, and $\mathrm{NH}_{4}{ }^{+}$; (2) the $\gamma$-elimination of homocysteine to 2-ketobutyrate, $\mathrm{H}_{2} \mathrm{~S}$, and $\mathrm{NH}_{4}{ }^{+}$; and (3) the $\beta$-or $\gamma$-replacement reaction between two cysteine or two homocysteine molecules, with lanthionine or homolanthionine as the co-products, respectively [324,325]. CBS and CSE expression can be tissue/cell specific, as both are needed to generate $\mathrm{H}_{2} \mathrm{~S}$ in some tissues, while one enzyme is sufficient in others [326,327]. These enzymes are found in numerous tissues in mammals [320]. In addition, 3-mercaptopyruvate sulfurtransferase (3-MST), cytosolic cysteine aminotransferase (CCAT) and mitochondrial cysteine aminotransferase (mCAT) can also produce $\mathrm{H}_{2} \mathrm{~S}$, but to a lesser extent [328]. CBS and CSE are expressed all over the body; however, $\mathrm{CBS}$ plays a major role in $\mathrm{H}_{2} \mathrm{~S}$ biosynthesis in the central nervous system 
whilst CSE is the main $\mathrm{H}_{2}$ S-synthesizing enzyme in the vasculature [329]. As the final product in cysteine metabolism catalyzed by CBS and CSE, however, $\mathrm{H}_{2} \mathrm{~S}$ generates negative feedback by inhibiting the bioactivities of CBS and CSE [330].

As a biological gas, $\mathrm{H}_{2} \mathrm{~S}$ can freely cross cell membranes to act as a signaling molecule to regulate numerous biological pathways, such as $\mathrm{Ca}^{2+}$ signaling, apoptosis, redox signaling, angiogenesis, vasodilation, and cardioprotection, etc. [331,332]. Under physiological conditions, the concentrations of $\mathrm{H}_{2} \mathrm{~S}$ in the human body are low since, once synthesized, it will be easily metabolized and oxidized in the mitochondria. In vivo, $\mathrm{H}_{2} \mathrm{~S}$ is oxidized to persulfide sulfur by sulfide:quinone oxidoreductase (SQR) or to thiosulfate $\left(\mathrm{SSO}_{3}{ }^{2-}\right)$ and sulfate $\left(\mathrm{SO}_{4}{ }^{2-}\right)$ by persulfide dioxygenase, rhodanese and/or sulfite oxidase [333]. This process seems to be important in oxygen $\left(\mathrm{O}_{2}\right)$-sensing cells and tissues including systemic and uterine vasculatures where $\mathrm{H}_{2} \mathrm{~S}$ has been proposed as an "oxygen sensor", which mediates the tissue response to hypoxia [334].

In recent years, $S$-sulfhydration or $S$-persulfidation has been identified to be the primary signaling mechanism for mediating $\mathrm{H}_{2} \mathrm{~S}$ action. Sulfhydration denotes the formation of -S-SH adducts in proteins, concerting free thiols (-SH) to persulfide (-SSH) groups in the reactive cysteines in proteins. Sulfhydration normally results in the increased reactivity of the modified cysteines due to the increased nucleophilicity of -SSH compared with -SH [335]. Since cysteine is an essential amino acid, this post-translational modification at reactive cysteines affects the entire proteome and thus inevitably participates in nearly all biological pathways. Malfunctions in this critical cellular process have been implicated as causal factors in numerous diseases, including preeclampsia [336-340]. This is testament to the importance of sulfhydration as a signaling process and explains the growing interest in understanding the regulation and mechanisms of the process. Indeed, there are many proteins that have been identified as sulfhydrated proteins. In some vessels, $\mathrm{H}_{2} \mathrm{O}_{2}$ is an endothelium-derived hyperpolarization factor (EDHF) whose function is mediated by oxidizing Cys ${ }^{42}$ in PKG to induce disulfide-linked PKG homodimerization and activation [341,342]. Mice with Cys ${ }^{42}$ in PKG replaced by serine are hypertensive and exhibit impaired vasorelaxation response to NaHS in their resistant vessels, suggesting that polysulfides derived from NaHS can stimulate PKG [343]. $\mathrm{H}_{2} \mathrm{~S}$ increases the $S$-sulfhydration of mitogen-activated protein kinase 1 (MEK1) in HUVEC, while mice lacking the CSE gene have lower sulfhydrated MEK1 [344]. Various ion channels are also target proteins that can be sulfhydrated by $\mathrm{H}_{2} \mathrm{~S}$, resulting in either increased activity, such as in voltage-activated $\mathrm{Ca}^{2+}$ channels in neurons [345-347] and $\mathrm{Cl}^{-} / \mathrm{HCO}_{3}{ }^{-}$exchangers in vascular SMC [348], or decreased activity, such as in L-type $\mathrm{Ca}^{2+}$ channels in SMC [349,350].

CSE-derived endogenous $\mathrm{H}_{2} \mathrm{~S}$ is a physiological vasorelaxant, as global CSE knockout mice display pronounced hypertension and diminished endothelium-dependent vasorelaxation in association with markedly reduced $\mathrm{H}_{2} \mathrm{~S}$ levels in the serum, heart, aorta, and other tissues [351]. $\mathrm{H}_{2} \mathrm{~S}$ can relax freshly prepared blood vessel rings from many vascular beds, including in cerebral [314], mesentery [352], coronary [353], uterine [37], and placental [338] arteries. However, unlike endogenous NO, which is exclusively produced by EC, endogenous $\mathrm{H}_{2} \mathrm{~S}$ in the vascular wall is synthesized by both EC and SMC and, collectively, they regulate vascular tone and homeostasis. The vasodilatory effects of $\mathrm{H}_{2} \mathrm{~S}$ have been shown to be mediated by the activation of the adenosine triphosphate (ATP)-sensitive $\mathrm{K}^{+}$-channel $\left(\mathrm{K}_{\mathrm{ATP}}\right)$ and $\mathrm{BK}_{\mathrm{Ca}}$ channels, resulting in SM relaxation [331,351,354]. In rat aortas, endogenous $\mathrm{H}_{2} \mathrm{~S}$ maintains whole-cell $\mathrm{K}_{\text {ATP }}$ currents, while exogenous $\mathrm{H}_{2} \mathrm{~S}$ activates $\mathrm{K}_{\text {ATP }}$ channels by increasing the availability of single channels of this type [355]. In freshly prepared endothelium-intact and denuded rat mesentery artery rings, exogenous $\mathrm{H}_{2} \mathrm{~S}$ from donors $(100 \mu \mathrm{M} \mathrm{NaSH})$ potently induces vascular relaxation, which is partially attenuated by the mixture of the endothelial small conductance $\mathrm{K}^{+}$channel $\left(\mathrm{SK}_{\mathrm{Ca}}\right)$ inhibitor apamin, and intermediate conductance $\mathrm{K}^{+}$-channel $\left(\mathrm{IK}_{\mathrm{Ca}}\right)$ inhibitor charybdotoxin, or the $\mathrm{K}_{\text {ATP }}$ channel inhibitor glibenclamide [337]. However, the dilatory effects of $\mathrm{H}_{2} \mathrm{~S}$ in rat mesentery arteries are not altered by the sGC inhibitor ODQ or the PKG inhibitor KT5823 [337]. These studies demonstrate that exogenous $\mathrm{H}_{2} \mathrm{~S}$ activates $\mathrm{K}^{+}$channels including endothelial $\mathrm{IK}_{\mathrm{Ca}}$, $\mathrm{SK}_{\mathrm{Ca}}$ and $\mathrm{K}_{\mathrm{ATP}}$, but not sGC and PKG, which are important for mediating the vasodilatory effects of $\mathrm{H}_{2} \mathrm{~S}$. These studies 
also suggest that activation of $\mathrm{K}_{\mathrm{ATP}}$ channels by $\mathrm{H}_{2} \mathrm{~S}$ is independent of the sGC-cGMP pathway, although $\mathrm{H}_{2} \mathrm{~S}$ can increase cGMP to activate PKG in EC [356].

Instead, $\mathrm{H}_{2} \mathrm{~S}$-induced vasorelaxation has been shown to be largely mediated by the cGMP-PKGindependent sulfhydration of various ion channels in vascular SM. For example, treatment with a $\mathrm{H}_{2} \mathrm{~S}$ donor, $\mathrm{Na}_{2} \mathrm{~S}$, dilates vessels via sulfhydrating the putative proangiogenic $\mathrm{Ca}^{2+}$-permeable transient receptor potential (TRP) V4 channels, resulting in a $\mathrm{Ca}^{2+}$ and $\mathrm{K}^{+}$influx in rat aortic artery ECs [357]. $\mathrm{H}_{2} \mathrm{~S}$ also sulfhydrates Kir 6.1 [337] and sulfonylurea 2B [358] in $\mathrm{K}_{\mathrm{ATP}}$ channels and $\mathrm{K}_{\mathrm{V}} 4.3$ in $\mathrm{K}_{\mathrm{V}}$ channels [359] in SMC to promote SM relaxation. Interestingly, pregnancy stimulates the expression and activation of various $\mathrm{K}^{+}$channels, including $\mathrm{BK}_{\mathrm{Ca}}$ and $\mathrm{K}_{\mathrm{ATP}}$ in the UA [360-362], most likely via the classical NO-cGMP-PKG and PKC pathways [363].

$\mathrm{H}_{2} \mathrm{~S}$ is also a potent pro-angiogenic factor because the pharmacological inhibition of CSE and CBS bioactivity or gene silencing using CBS or CSE siRNAs results in reduced angiogenesis in multiple in vivo angiogenesis models $[356,364]$ and exogenous $\mathrm{H}_{2} \mathrm{~S}$ also stimulates angiogenesis in vitro and in vivo $[356,365,366]$. The angiogenic activity of $\mathrm{H}_{2} \mathrm{~S}$ is mediated by the activation of the cGMP pathway as ODQ and $\mathrm{KT} 5823$ can partially block $\mathrm{H}_{2} \mathrm{~S}$-induced angiogenesis [356,364]. Moreover, exogenous and endogenous $\mathrm{H}_{2} \mathrm{~S}$ activates EC eNOS/NO during in vitro and in vivo angiogenesis [356,367]. Endothelial eNOS-derived $\mathrm{NO}$ is a physiological angiogenic factor [368]. These studies suggest that $\mathrm{H}_{2} \mathrm{~S}$ regulates angiogenesis by interacting with eNOS/NO. Additionally, exogenous and endogenous $\mathrm{H}_{2} \mathrm{~S}$ has been shown to induce apoptosis and inhibit proliferation in human and rat aortic SMC in vitro via the activation of MAPK pathways [369-371].

Whether or not the $\mathrm{H}_{2} \mathrm{~S}$ system was present in the UA was not known until 2015, after we first reported that exogenous $\mathrm{E}_{2} \beta$ stimulates $\mathrm{UA} \mathrm{H}_{2} \mathrm{~S}$ production via the selective upregulation of CBS expression in OVX nonpregnant (NP) ewes [372]. In that study, we first posited the novel role of $\mathrm{H}_{2} \mathrm{~S}$ in the pregnancy-associated rise in UtBF because of the potent vasodilatory effects of $\mathrm{H}_{2} \mathrm{~S}$, as discussed above. Indeed, we were recently the first to report that $\mathrm{UA}_{2} \mathrm{~S}$ production is significantly augmented with a nine-fold increase in EC/SM CBS protein, but not CSE and other enzymes (3MST and CAT), in pregnant, but not nonpregnant, ewes [373] in vivo and in women [37] ex vivo. We also reported that a slow-releasing $\mathrm{H}_{2} \mathrm{~S}$ donor GYY4237 dose-dependently stimulates relaxation of phenylephrine-preconstricted UA rings isolated from both pregnant and nonpregnant rats, but with significantly greater potency in the pregnant state (Figure 4). In addition, GYY4237 does not relax the mesentery artery in pregnant rats [37]. Thus, our findings show that $\mathrm{H}_{2} \mathrm{~S}$ stimulates pregnancy-dependent UA vasodilation, establishing $\mathrm{H}_{2} \mathrm{~S}$ 's function as a "new" UA vasodilator.
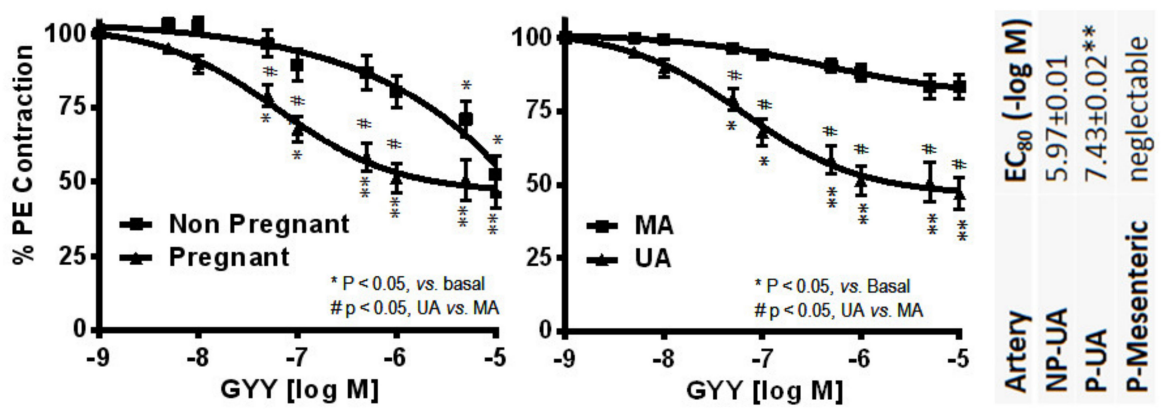

Figure 4. Hydrogen sulfide $\left(\mathrm{H}_{2} \mathrm{~S}\right)$ functions as a "new" uterine artery dilator. Endothelium intact primary uterine (UA, $n=12-18$ ) and secondary mesenteric (MA, $n=12$ ) arteries isolated from pregnant (P) (gestation day 20) and nonpregnant (NP) Sprague-Dawley rats. Artery rings were preconstricted with $10^{-6} \mathrm{M}$ phenylephrine and exposed to a slow releasing $\mathrm{H}_{2} \mathrm{~S}$ donor morpholin-4-ium-4-methoxyphenyl(morpholino) phosphinodithioate (GYY4137) $\left(10^{-9}-10^{-5} \mathrm{M}\right)$. ${ }^{*} p<0.05,{ }^{* *} p<0.01$, for differences within the same dose; $p<0.05$ vs. NP-UA, or vs. P-MA in the same dose. The potency of GYY4137 in dilating each artery is compared using $\mathrm{EC}_{80}$, which is calculated as the $\log (\mathrm{M})$ of the dose that induces $80 \%$ dilation. ${ }^{* *} p<0.01$ vs. NP-UA. Adapted from Sheibani et al., Biol. Reprod. 2019; 96:664-672 (37). 
Our recent work has shown that UAEC and UASMC $\mathrm{H}_{2} \mathrm{~S}$ biosynthesis is stimulated by exogenous estrogens [372] and is also augmented during ovine [373] and human pregnancy [37], correlating with endogenous estrogens. Notably, exogenous and endogenous estrogens stimulate $\mathrm{UA}_{2} \mathrm{~S}$ biosynthesis via the selective upregulation of CBS but not CSE mRNA and protein expressions in EC and SMC ex vivo $[37,372,373]$. However, unlike systemic arteries in which CSE seems to be the enzyme for $\mathrm{H}_{2} \mathrm{~S}$ production [329], our data consistently show that CBS is the major enzyme responsible for augmenting $\mathrm{UA}_{2} \mathrm{~S}$ biosynthesis because other $\mathrm{H}_{2} \mathrm{~S}$ producing enzymes, i.e., $\mathrm{CSE}, 3 \mathrm{MST}$, $\mathrm{mCAT}$, and cCAT, are not altered in human UA in the menstrual cycle and during pregnancy [37].

We have further studied the mechanisms controlling UA $\mathrm{H}_{2} \mathrm{~S}$ biosynthesis upon estrogen stimulation. In a similar manner to in vivo conditions, treatment with $\mathrm{E}_{2} \beta$ increases CBS mRNA and protein in both ovine UAEC [142] and UASMC [70] models in a time- and concentration-dependent manner in vitro, suggesting that the UA CBS gene may be regulated by estrogens and by transcriptional mechanisms during pregnancy. The human $C B S$ promoter contains multiple putative cis elements for binding various transcription factors, including ERE and binding sites for SP-1, AP-1, and AP-3 [374,375]; when transfected into both UAEC and UASMC, treatment with $E_{2} \beta$ results in the transactivation of the human CBS promoter in both cell models [70,142]. Notably, treatment with PPT, DPN, or their combination, stimulates CBS mRNA and protein expressions to levels similar to that of $\mathrm{E}_{2} \beta$-induced responses in both ovine UAEC and UASMC. On the other hand, co-treatment with MPP, PHTPP, or both, completely blocked $\mathrm{E}_{2} \beta$-induced CBS expression. These findings show that the activation of either $E R \alpha$ or $E R \beta$ suffices to mediate $C B S$ transcription in response to estrogens on the UA wall.

Treatment with $E_{2} \beta$ also stimulates CSE mRNA and protein expression via ER $\alpha$ and/or ER $\beta$-dependent transcription in ovine UAEC and UASMC in vitro [70,142]. These data demonstrate that CSE is also an estrogen-responsive gene in UAEC and UASMC in vitro. Although the CSE promoter also contains EREs [374,375], the estrogen stimulation of CSE expression in UAEC and UASMC in vitro is unexpected because it contradicts not only our ex vivo studies showing that exogenous or endogenous $E_{2} \beta$ does not alter CSE mRNA and protein in UA endothelium in women [37] ex vivo and sheep $[372,373]$ in vivo and ex vivo, but also other studies showing that $E_{2} \beta$ does not stimulate CSE expression in mouse mesenteric SMC in vitro [376]. The discrepancy between the effect of estrogens on CSE expression in UA in vitro and ex vivo is currently unknown, but may, in part, result from the loss of cell-cell interactions and the microenvironment in which EC and SMC reside ex vivo. Nonetheless, these studies urge that caution should be exercised when interpreting in vitro findings as they pertain to ex vivo conditions, because they can sometimes produce different outcomes. We have developed novel human UAEC and UASMC models from pregnant and nonpregnant women for uterine hemodynamics research. In these cells, we found that pregnancy augments VEGF-stimulated $\mathrm{H}_{2} \mathrm{~S}$ production by the selective upregulation of CBS expression, without altering CSE expression in vitro [250]. Primary human UAEC retains the pregnancy-dependent expression of ER $\alpha$ and ER $\beta$ in culture. Treatment with $E_{2} \beta$ dose-dependently stimulates angiotensin $A 2$ receptor $\left(A_{2} R\right)$ expression in human UAEC prepared from pregnant (but not nonpregnant) women, which is mediated by ER $\beta$ interactions with specific EREs in the human $\mathrm{AT}_{2} \mathrm{R}$ promoter [377]. These studies suggest species differences in UAEC and UASMC in response to estrogens in vitro.

More recently, it was shown that $\mathrm{E}_{2} \beta$ can rapidly stimulate $\mathrm{H}_{2} \mathrm{~S}$ release within minutes in hUAEC in vitro. This rapid $\mathrm{H}_{2} \mathrm{~S}$ release in response to estrogens is mediated by ER $\alpha$ interaction with the $\mathrm{G} \alpha$ subunit $\mathrm{G} \alpha \mathrm{i}-2 / 3$ on the plasma membrane, resulting in the transactivation of particulate guanylate cyclase- $A(p G C-A)$ for generating cGMP, thereby activating PKG-I; activated PKG-I then phosphorylates CSE to increase $\mathrm{H}_{2} \mathrm{~S}$ production. The silencing of either CSE or $p G C-A$ in blunted estrogen-induced aorta vasodilation in mice suggests that this nongenomic pathway may plays a role in estrogen-induced vasodilation via endothelial CSE- $\mathrm{H}_{2} \mathrm{~S}$ [165]. CBS can also be phosphorylated on serine ${ }^{227}$ directly by $P K G$, resulting in the action of the enzyme and thereby increasing $\mathrm{H}_{2} \mathrm{~S}$ production [378]. However, whether GPER or ER $\beta$ also play a role in the nongenomic activation of CSE and whether CBS has a 
role in rapid $\mathrm{H}_{2} \mathrm{~S}$ production in response to estrogens are unknown. It is also not known whether nongenomic pathways of estrogen signaling also regulate (in $\mathrm{UA}$ ) $\mathrm{H}_{2} \mathrm{~S}$ production.

Nonetheless, it is important to point out that research on $\mathrm{H}_{2} \mathrm{~S}$ in uterine hemodynamic regulation during pregnancy is still in its early stages in comparison to $\mathrm{NO}$ and $\mathrm{CO}$. There is much to be learned before a definite physiological role of endogenous $\mathrm{H}_{2} \mathrm{~S}$ in estrogen-induced and pregnancy-associated uterine vasodilation in pregnancy can be established for exploring the therapeutic potential of $\mathrm{H}_{2} \mathrm{~S}$ in pregnancy complications.

\section{4. $\mathrm{H}_{2} \mathrm{~S}$ Interactions with $\mathrm{NO}$ and $\mathrm{CO}$ in the Vasculature}

$\mathrm{NO}, \mathrm{CO}$, and $\mathrm{H}_{2} \mathrm{~S}$ are formed in the UA endothelium and/or SM in the vascular wall. With a half-life between seconds $(\mathrm{NO})$ and minutes $\left(\mathrm{CO}\right.$ and $\left.\mathrm{H}_{2} \mathrm{~S}\right)$, each can activate specific pathways to regulate vascular tone and homeostasis independently. An obviously question is, among the three, what is the relative significance in regulating vascular tone and homeostasis? The available evidence, however, cannot distinguish their relative significance from one another, but rather supports an idea that the three function coordinatively in the cardiovascular system: for example, as discussed above, $\mathrm{H}_{2} \mathrm{~S}$ and NO stimulate distinct and common pathways to elicit their angiogenic and vasodilatory effects. However, $\mathrm{H}_{2} \mathrm{~S}$ and $\mathrm{NO}$ stimulate angiogenesis in vivo in a mutually exclusive manner [379]. In addition, $\mathrm{H}_{2} \mathrm{~S}$-induced rat aortic artery vasorelaxation can be partially attenuated by either endothelium removal or the application of L-NAME to endothelium-intact rings [331], suggesting that the dilatory effects of $\mathrm{H}_{2} \mathrm{~S}$ on the aortic artery are partially endothelium/NO-dependent. In this context, it is proposed that an intact endothelium might serve as a physical buffer system to retain $\mathrm{H}_{2} \mathrm{~S}$ in the vessel wall so that its vasorelaxant effect can be potentiated and prolonged [331]. However, endogenous $\mathrm{H}_{2} \mathrm{~S}$ or $\mathrm{H}_{2} \mathrm{~S}$ donors stimulate eNOS phosphorylation and NO production in EC [356,367], suggesting that $\mathrm{H}_{2} \mathrm{~S}$ functions upstream of the eNOS-NO pathway in the vasculature. Although most studies have shown that $\mathrm{H}_{2} \mathrm{~S}$ positively cooperates with $\mathrm{NO}$ in the vascular system, the concentrations of $\mathrm{H}_{2} \mathrm{~S}$ donors used are relatively high in these studies. In contrast, less than $100 \mu \mathrm{M} \mathrm{NaHS}$ is shown to be paradoxically vasoconstrictive by suppressing cAMP production in vascular SMC, and to reverse vasorelaxation induced by endothelium-derived vasodilators such as acetylcholine and histamine; this contractile activity of $\mathrm{H}_{2} \mathrm{~S}$ is attributed to the direct inhibition of eNOS [380]. In addition, high concentrations of $\mathrm{H}_{2} \mathrm{~S}$, like $\mathrm{NO}$ and $\mathrm{CO}$, are cytotoxic and induce cell death. Thus, the biological functions of all three depend on a U-shaped local concentration-dependent manner.

The interplay between $\mathrm{H}_{2} \mathrm{~S}$ and $\mathrm{NO}$ might not exert enhancement or potentiation effects. Ali et al. showed that $\mathrm{NaSH}$ treatment can diminish the vasorelaxant effects induced by each NO donor [sodium nitroprusside (SNP), morpholinosidonimine (SIN-1) and S-nitroso- $N$-acetylpenicillamine (SNAP)] in rat aortas [381], suggesting that the interaction of $\mathrm{H}_{2} \mathrm{~S}$ and $\mathrm{NO}$ may form a product that does not respond to vasorelaxant effects. The product of interaction has been characterized by the fact that SNP prevents the relaxation effects of $\mathrm{H}_{2} \mathrm{~S}$ by the generation of nitroxyl (HNO) [382]. $\mathrm{H}_{2} \mathrm{~S}$ conditionally reacts with $S$-nitrosothiols, resulting in the formation of thionitrous acid, the smallest $S$-nitrosothiol (HSNO), which serves as a $\mathrm{NO}, \mathrm{NO}^{+}$, and $\mathrm{HNO}$ donor, depending on the reaction condition [383]. Cortese-Krott et al. first demonstrated that the short-lived HSNO has the potential to react with sulfide, forming multiple bioactive products, including the nitrosopersulfide $\mathrm{SSNO}^{-}$, which can sustainably generate $\mathrm{NO}$ and polysulfides on decomposition, accompanied by the nitrosothiol-induced stimulation of sGC signaling [384]. To display the sustainable $\mathrm{SSNO}^{-}$effects via $\mathrm{NO} / \mathrm{H}_{2} \mathrm{~S}$ interplay, Berenyiova et al. recently prepared the product "SSNO${ }^{-}$mix" via the interaction between $\mathrm{Na}_{2} \mathrm{~S}$ and the NO donor $S$-nitrosoglutathione (GSNO) based on Cortese-Krott's study [385]. In rat uteri, GSNO showed a weaker relaxation effect than sulfide on uterine contractility; the interaction of sulfide/GSNO could diminish the relaxation effects, even at a 1:10 ratio [385]. Meanwhile, GSNO relaxed the pre-restricted rat aortic rings with a stronger and faster effect than sulfide, but a weaker one than "SSNO- mix". This study on sulfide, GSNO and the reaction products of the sulfide/GSNO interaction has indicated that their effects on uterine and vascular SM are different, and the products of the sulfide/GSNO interaction can 
account for the sGC activation [385]. However, the vasorelaxation effects of the products formed from sulfide/GSNO interaction are yet to be determined in the uterine vasculature.

$\mathrm{CO}$ and NO share many similar functions, as they activate common downstream signaling pathways. In addition, $\mathrm{HO}$ proteins share a high homology in the C-terminal amino acid sequence with NOS [386]. In response to low-concentration CO stimulation, vascular EC and blood platelets release $\mathrm{NO}$ and generate peroxynitrite [387]. In the aortic artery endothelium, HO-1 and HO-2 concomitantly express with eNOS, collaboratively contributing to vasodilation [388]. This suggests that the HO/CO and eNOS/NO systems also interact with each other in the vascular system. However, the functions of $\mathrm{CO}$ and NO can be different. For example, $\mathrm{CO}$ stimulates sGC activity with a low tissue NO level, whereas CO inhibits sGC activity with a high tissue NO level [389]. Thus, the potential interplays between $\mathrm{CO}$ and $\mathrm{NO}$ also occur in different manners, being synergistic or antagonistic, and dependent on local concentrations.

Most studies regarding interactions among gasotransmitters are in the context of $\mathrm{NO}$ and $\mathrm{H}_{2} \mathrm{~S}$ and $\mathrm{NO}$ and $\mathrm{CO}$. However, the interaction between $\mathrm{CO}$ and $\mathrm{H}_{2} \mathrm{~S}$ is very understudied. Exogenous $\mathrm{H}_{2} \mathrm{~S}$ is able to increase HO-1 expression and CO production, thereby alleviating the elevation of pulmonary arterial pressure in a chronic hypoxic animal model [390], suggesting that $\mathrm{H}_{2} \mathrm{~S}$ and $\mathrm{CO}$ interact in pulmonary SMC to regulate blood pressure. However, in cultured aortic SMC, the blockage of endogenous CO by a HO-1 inhibitor zinc protoporphyrin (ZnPP) decreased CSE expression and $\mathrm{H}_{2} \mathrm{~S}$ production, while the inhibition of CSE by propargylglycine (PAG) increased HO-1 expression and CO production, but treatment with $\mathrm{NaSH}(100 \mu \mathrm{M})$ decreased HO-1 expression [391]. These results suggest that endogenous $\mathrm{H}_{2} \mathrm{~S} / \mathrm{CSE}$ and $\mathrm{CO} / \mathrm{HO}$ systems seem to antagonize one another in aortic SMC in vitro.

The interactions among $\mathrm{NO}, \mathrm{CO}$, and $\mathrm{H}_{2} \mathrm{~S}$ certainly provide another dimension to the complexity of gasotransmitter signaling and function in the vascular system. All three have been shown to play sometimes redundant or important roles in the uterine vasculature, but their interactions in regulating uterine hemodynamics are unknown. However, it is expected that their complimentary interactions are important since, when one system is dysfunctional, it may be compensated by the other(s) [392].

\section{Estrogens and Gasotransmitters in Preeclampsia}

\subsection{Pathophysiological Evidence}

Preeclampsia (PE) is a pregnancy disorder characterized by blood pressure greater than $140 / 90 \mathrm{mmHg}$ and proteinuria that weighs more than $0.3 \mathrm{~g}$ per day after the 20th week of gestation in previously normotensive and nonproteinuric pregnant women [393,394]. It affects $2-8 \%$ of pregnant women in developed countries and $15-20 \%$ of all pregnancies in developing countries $[395,396]$. Preeclampsia is a major pregnancy complication that increases maternal and perinatal mortality and morbidity. The pathogenesis of PE is incompletely understood. Although there are many different phenotypes of PE, the common denominator is the placenta, as the clinical manifestations disappear within a few days after the delivery of the placenta [397]. It is generally believed that shallow trophoblast invasion and impaired uterine spiral artery remodeling during placentation results in decreased UtBF to the placenta; ischemia/hypoxia further stimulates placenta production of harmful factors such as inflammatory cytokines [i.e., tumor necrosis factor $\alpha$ (TNF $\alpha$ ) and interleukin 6 (IL-6)] and antiangiogenic factors (i.e., soluble fms-like tyrosine kinase (sFlt-1), and soluble endoglin), which further cause systemic inflammation and endothelial dysfunction [398,399].

Circulating estrogen levels have, in general, been found to be decreased in preeclamptic women compared normotensive women during pregnancy [400]. Low estrogen levels during pregnancy are also associated with insufficient UtBF to the gravid uterus as well as pregnancy complications such as preterm delivery, intrauterine fetal growth restriction, and PE [401,402]. During pregnancy, estrogens are primarily produced by the placenta [15] and they promote angiogenesis and vasodilation [403]; ischemia/hypoxia-induced aromatase deficiency to the placenta can result in decreased estrogen production in PE [404]. With more reliable methods for accessing estrogens and 
their metabolites, studies have further validated a close link between estrogen dysregulation and PE [402]. Mice deficient of catechol-O-methyltransferase, which converts $17 \beta$-triol to one of its major metabolites, 2-methoxyoestradiol, develop PE-like symptoms [405], further supporting the causal role of reduced estrogens in PE.

Although measurements of $\mathrm{NO}$ and its metabolites (nitrite and nitrate) in pregnancy have resulted in conflicting results [406-408], there is a consensus that NO bioavailability is significantly decreased because endothelial NO production is reduced, as dysfunctional EC is a hallmark of PE [254,409] or because eNOS is uncoupled to produce superoxide $\left(\mathrm{O}_{2}^{-}\right)$[410]. In preeclamptic women, decreased $\mathrm{NO}$ bioavailability and increased $\mathrm{O}_{2}{ }^{-}$result in the formation of $\mathrm{ONOO}^{-}$, which is a potent cytotoxic anion that interacts with tyrosine to decrease protein function via nitrosation [411], resulting in further placental damage, EC dysfunction, and inflammation in PE. In addition, reduced NO lowers UtBF, which results in the impairment of shear stress-mediated NO release and diminished UA remodeling [412]. This mechanism is supported by the NOS antagonist L-NAME-inhibited matrix metalloproteinase (MMP)/metallopeptidase inhibitor (TIMP) pathway in pregnant rats, with increased arterial wall collagen and elastin content and impaired expansive remodeling compared to normal pregnancy [277].

HO-2 expression on syncytiotrophoblast is highest in early human pregnancy and reduces toward term [413]. However, placental villous endothelial HO-2 expression is notably reduced in PE and IUGR pregnancies [414]. Indeed, the end tidal CO (ETCO) levels are significantly lower in PE than gestationally hypertensive and normal pregnant women [317]. Chronic exposure to CO at $250 \mathrm{ppm}$ dilates UA and UtBF in mice [415]; this may explain the lower incidence of PE in pregnant women who smoke, since cigarette smoking releases increased CO levels in the maternal blood [415]. These observations suggest that the $\mathrm{HO} / \mathrm{CO}$ system is important for uterine hemodynamics regulation during normal pregnancy and that its dysfunction is a causal factor for PE.

Genetic CBS deficiency results in homocysteinemia, causing endothelial dysfunction and hypertension in both animals and humans [416]. CSE knockout mice display reduced serum $\mathrm{H}_{2} \mathrm{~S}$ levels, accompanied by hypertension and diminished vasodilation [351]. These observations have provided direct evidence of the role of endogenous $\mathrm{H}_{2} \mathrm{~S}$ in the maintenance of vascular health. Human placental CSE and CBS expression and $\mathrm{H}_{2} \mathrm{~S}$ production are reduced in $\mathrm{PE}[338,417]$. The inhibition of placenta $\mathrm{CSE} / \mathrm{H}_{2} \mathrm{~S}$ production by PAG results in PE-like symptoms in mice due to impaired placental angiogenesis [338]; $\mathrm{H}_{2} \mathrm{~S}$ supplementation using $\mathrm{NaSH}$ or GYY4237 reverses sFlt-1-induced hypertension and proteinuria in rats $[338,418]$. Moreover, spiral artery CSE downregulation mediated by miR21 upregulation is associated with abnormal UA remodeling and umbilical artery Doppler profiles in IUGR and PE pregnancies [419]. These studies have established the causal role of the CBS/CSE- $\mathrm{H}_{2} \mathrm{~S}$ system in uterine and placental vascular development and function in pregnancy and have also provided a premise that $\mathrm{H}_{2} \mathrm{~S}$ is a potential therapeutic target for PE and IUGR.

\subsection{Therapeutic Considerations}

The clinical manifestations (i.e., new onset hypertension and proteinuria) of PE are diagnosed after the 20th week of gestation. Current treatments for PE are aimed at normalizing the blood pressure rather than targeting the placenta pathology itself, but none of these are satisfactory; hypertension is reduced transiently, allowing Caesarean delivery to be set up before term. Once clinical manifestations of PE have developed, theoretically, it should be too late to correct placenta defects as a target for the therapeutic development for $\mathrm{PE}$, since the formation of a fully functional placenta has been completed before the 20th week of gestation. Improving UtBF provides an attractive alternative for managing clinical PE (i.e., hypertension) to extend gestation safely so that premature delivery can be avoided.

Short-term $\mathrm{E}_{2} \beta$ treatment in PE women reduces clinical symptoms in association with decreased oxidative stress by reducing the production of oxidants, i.e., $\mathrm{O}^{-}, \mathrm{H}_{2} \mathrm{O}_{2}, \mathrm{NO}_{2}^{-}$, and $\mathrm{ONOO}^{-}[420,421]$. However, too many off-target effects prevent estrogens being used as a therapeutic target for PE. Animals treated with L-NAME to inhibit endogenous NO production develop PE-like symptoms [422]. 
Likewise, the NO pathway is perhaps the most studied as a potential therapy target for PE, including endogenous S-nitrosothiol GSNO, the NO precursor L-arginine, the PDE5 inhibitor sildenafil, etc. [423]. GSNO improves endothelial function, reduces platelet aggregation, and promotes UtBF [423-425]. In a randomized controlled trial, it was shown that pregnant women at high risk of PE benefit from dietary supplementation with a combination of L-arginine and antioxidants, but not $\mathrm{L}$-arginine or antioxidants alone [426]. Subsequently, the beneficial effect of $\mathrm{L}$-arginine has been confirmed in seven controlled randomized trials showing that $\mathrm{L}$-arginine supplementation is manifested with a significant reduction in the risk to pregnant women with established or suspected PE [427]. Bolstering endogenous NO signing using sildenafil and its derivatives has been investigated extensively for treating PE. Despite its promising results in many preclinical animal studies, human studies have shown a 4-day extension in gestation in severe PE patients [428]. However, a very recent clinical trial showed the beneficial effects of sildenafil in treating pregnant women with a high risk of IUGR; however, unfortunately, the trial was halted because infants born to women receiving the drug died from pulmonary hypertension [429].

Statins are medicines that were originally developed for hypercholesterolemia [430], with a known protective effect on vascular EC [431,432] and a stimulatory effect on CO-synthesizing enzyme HO expression [433]. Mice treated with statins have shown to possess elevated levels of CO production and increased levels of plasma antioxidants, which are abrogated by $\mathrm{HO}$ inhibitors, indicating that the $\mathrm{HO} / \mathrm{CO}$ pathway may mediate the vasodilatory actions of statins [434]. Statins do not seem to be teratogenic; however, the available evidence only shows limited, yet promising, efficacy in treating and preventing PE [435].

Wang and colleagues have provided preclinical evidence for targeting the placental CSE/ $\mathrm{H}_{2} \mathrm{~S}$ pathway as a promising approach for treating PE [338]. They found that the inhibition of the CSE/ $\mathrm{H}_{2} \mathrm{~S}$ pathway by PAG induces hypertension and liver damage, promotes abnormal labyrinth vascularization in the placenta, and decreases fetal growth in mice; GYY4137 supplementation inhibits circulating soluble Flt-1 levels and restores fetal growth in PAG-treated dams [338]. Another study provides further preclinical evidence of the therapeutic potential of $\mathrm{H}_{2} \mathrm{~S}$ in treating PE, because 8 days of treatment with $\mathrm{NaHS}(50 \mu \mathrm{mol} / \mathrm{kg})$ decreased hypertension, proteinuria, and endotheliosis in sFlt-1-induced PE rats, in association with increased kidney VEGF production [418]. However, to date, no clinical trials have been reported on targeting $\mathrm{H}_{2} \mathrm{~S}$ for PE. Notably, the consumption of natural products such as garlic is associated with a lower incidence of hypertension due to its antioxidant properties and inhibition of platelet aggregation [436]. Garlic-rich diets contain high organic polysulfides that exert $\mathrm{H}_{2} \mathrm{~S}$ effects, which have been proposed to prevent and ameliorate cardiovascular disease [437]. Currently, clinical trials are being undertaken to test the beneficial effects of these kinds of "medical foods" or nutraceuticals, such as the slow-releasing $\mathrm{H}_{2} \mathrm{~S}$ donor diallyl trisulfide (DATS, [366]) and sulfur-releasing sodium polysulthionate (SG-1002, [332]) in cardiovascular diseases. It would be interesting to test whether these natural " $\mathrm{H}_{2} \mathrm{~S}$ ” donors have beneficial effects on PE.

\section{Conclusions}

Estrogens are pluripotent steroid hormones that regulate numerous physiological processes in the human body. Estrogen signaling in the uterine vasculature remains a fascinating yet understudied research area. The biological effects of estrogen are mediated by multiple ERs that activate multiple signaling pathways under the influence of physiological (e.g., pregnancy) and pathophysiological (e.g., preeclampsia) conditions, adding more complexity to the understanding of estrogen-induced uterine vasodilation. Estrogens and their metabolites are potent uterine vasodilators in the nonpregnant state, and these effects are further augmented during pregnancy. The vasodilatory effects of estrogens in the uterine and selected systemic arteries are well established as being largely mediated by ER-mediated genomic and nongenomic pathways, they involve the enhanced production of NO by the EC and CO and $\mathrm{H}_{2} \mathrm{~S}$ by both EC and SMC locally, in specific vascular beds. However, the mechanisms of how each of the $\mathrm{NO}, \mathrm{CO}$, and $\mathrm{H}_{2} \mathrm{~S}$ systems is regulated and how they interact to participate in estrogen-induced uterine vasodilation in pregnancy are yet to be discovered. Nonetheless, enhanced local UA production 
of gasotransmitters provides the promise that targeting these signals can be used to develop therapeutics for preeclampsia and IUGR. However, to make this promise into a reality, more research in this area is needed, because targeting these pathways has hitherto failed or only achieved minimal success in treating or preventing PE and IUGR. Nonetheless, the $\mathrm{H}_{2} \mathrm{~S}$ pathway in pregnancy is the least studied among the three. The emerging role of $\mathrm{H}_{2} \mathrm{~S}$ in estrogen-induced uterine vasodilation in pregnancy should be studied further so that the physiological role of enhanced endogenous $\mathrm{H}_{2} \mathrm{~S}$ and the pathophysiological role of dysregulated $\mathrm{H}_{2} \mathrm{~S}$ in pregnancy complications such as PE and IUGR can be established. Furthermore, the interactions among $\mathrm{NO}, \mathrm{CO}$, and $\mathrm{H}_{2} \mathrm{~S}$ should be taken into special consideration in future studies aiming to develop therapies for pregnancy complications.

Author Contributions: J.B. and D.-b.C. conceived the idea and wrote the paper, Q.-R.Q., Y.L., R.D., J.M. and R.R.M. added intellectual input and edited the paper, and all authors approved the submission. All authors have read and agreed to the published version of the manuscript.

Funding: The present study was supported in part by National Institutes of Health (NIH) Grants HL70562, HL98746, and HD097498 (to D.-b.C.), and HL117941(to R.R.M.); Q.-r.Q. is an American Heart Association Postdoctoral Fellow (AHA 20POST35090000). The content is solely the responsibility of the authors and does not necessarily reflect the official views of the NIH and AHA.

Conflicts of Interest: The authors declare no conflicts of interest.

\section{Abbreviations}

3-Mercaptopyrivate sulfurtransferase (3-MST); acetylcholine (ACH); protein kinase $\mathrm{B}(\mathrm{Akt})$; activator protein 1 (AP-1); angiotensin $\mathrm{A} 2$ receptor $\left(\mathrm{AT}_{2} \mathrm{R}\right)$; large conductance $\mathrm{Ca}^{2+}$-activated potassium channel $\left(\mathrm{BK}_{\mathrm{Ca}}\right)$; bovine serum albumin (BSA); cyclic adenosine $3^{\prime} 5^{\prime}$-monophosphate (cAMP); cystathionine $\beta$-synthase (CBS); CBS cytosolic cysteine aminotransferase (CBS); cyclic guanosine monophosphate (cGMP); carbon monoxide (CO); carboxyhemoglobin $(\mathrm{COHb})$; cystathionine- $\gamma$-lyase (CSE); cAMP response element-binding protein (CREB); diallyl trisulfide (DATS); DNA binding domain (DBD); diarylpropionitrile (DPN); estradiol-17 $\beta\left(\mathrm{E}_{2} \beta\right)$; estetrol $\left(\mathrm{E}_{4}\right)$; endothelial cell (EC); endothelium-derived hyperpolarizing factor (EDHR); endothelium-derived relaxing factor (EDRF); epidermal growth factor (EGF); epidermal growth factor receptor (EGFR); ethylene glycol-bis ( $\beta$-aminoethyl ether)- $N, N, N^{\prime}, N^{\prime}$-tetraacetic acid (EGTA); extracellular signal-regulated kinases $\frac{1}{2}\left(\right.$ ERK $\frac{1}{2}$ ); endothelial nitric oxide synthase (eNOS); estrogen receptor (ER); estrogen-responsive element (ERE); estrogen replacement therapy (ERT); end tidal carbon monoxide (ETCO); fetal bovine serum (FBS); fibroblast growth factor (FGF); G protein-coupled estrogen receptor (GPER); S-nitrosoglutathione (GSNO); morpholin-4-ium-4-methoxyphenyl(morpholino) phosphinodithioate (GYY4137); heme oxygenase (HO); hydrogen sulfide $\left(\mathrm{H}_{2} \mathrm{~S}\right)$; nitroxyl $(\mathrm{HNO})$; human umbilical cord vein endothelial cell (HUVEC); iberiotoxin (iBTX); insulin-like growth factor 1 (IGF1); interleukin 6 (IL-6); intermediate conductance potassium channel $\left(\mathrm{IK}_{\mathrm{Ca}}\right)$; inducible nitric oxide synthase (iNOS); insulin receptor substrate 1 (IRS-1); intrauterine growth restriction (IUGR); adenosine triphosphate-sensitive potassium channel $\left(\mathrm{K}_{\mathrm{ATP}}\right)$; voltage-gated potassium channel $\left(\mathrm{K}_{\mathrm{v}}\right)$; ligand binding domain (LBD); $N(\omega)$-nitro-L-arginine methyl ester (L-NAME); cCAT mitochondrial cysteine aminotransferase (mCAT); mitogen-activated protein kinase (MAPK); mitogen-activated protein kinase 1 (MEK1); multiple expectation maximization for motif elicitation (MEME); matrix metalloproteinase (MMP); 1,3-bis(4-hydroxyphenyl)-4-methyl-5-[4-(2-piperidinylethoxy)phenol]-1H-pyrazole dihydrochloride (MPP); nicotinamide adenine dinucleotide phosphate (NADPH); $N$-terminal transactivation domain (NBD); N-methyl-D-aspartate (NMDA); neuronal nitric oxide synthase (nNOS); nitric oxide (NO); nitrate $\left(\mathrm{NO}^{-}\right)$; nitrite $\left(\mathrm{NO}_{3}^{-}\right)$; nitric oxide synthase (NOS); nuclear respiratory factor (Nrf); superoxide $\left(\mathrm{O}_{2}{ }^{-}\right)$; 1- $\mathrm{H}$-[1,2,4] oxadiazolo[4,3-a]quinoxalin-l-one (ODQ); oxyhemoglobin $(\mathrm{OHb})$; peroxynitrite $\left(\mathrm{ONOO}^{-}\right)$; ovariectomized (OVX); propargylglycine (PAG); phosphodiesterase (PDE); preeclampsia (PE); putative estrogen receptor (pER); particulate guanylate cyclase-A (pGC-A); 4-[2-phenyl-5,7-bis (trifluoromethyl)pyrazolo [1,5-a]pyrimidin-3yl]phenol (PHTPP); phosphoinositide 3-kinases (PI3K); protein kinase B (PKB/AKT); protein kinase G (PKG); propylpyrazoletriol (PPT); receptor tyrosine kinase (RTK); soluble fms-like tyrosine kinase (sFLT-1); sodium polysulthionate (SG-1002); soluble guanylyl cyclase (sGC); thiols (-SH); morpholinosidonimine (SIN-1); small conductance $\mathrm{K}^{+}$channel ( $\mathrm{SK}_{\mathrm{Ca}}$ ); smooth muscle cell (SMC); $S$-nitroso- $N$-acetylpenicillamine (SNAP); $S$-nitrosylation (SNO); sodium nitroprusside (SNP); sulfate $\left(\mathrm{SO}_{4}{ }^{2-}\right)$; specificity protein 1 (SP-1); sulfide: quinone oxidoreductase (SQR); steroid receptor fact action complex (SRFC); persulfide (-SSH); thiosulfate $\left(\mathrm{SSO}_{3}{ }^{2-}\right)$; tetraethylammonium chloride (TEA); ten-eleven translocation (TET); metallopeptidase inhibitor (TIMP); tumor necrosis factor $\alpha(\mathrm{TNF} \alpha)$; transient receptor potential (TRP); uterine artery (UA); uterine artery endothelial cell (UAEC); uterine artery smooth muscle cell (UASMC); uterine natural killer (uNK); uterine blood flow (UtBF); ultraviolet (UV); vascular endothelial growth factor (VEGF); zinc protoporphyrin (ZnPP). 


\section{References}

1. Garris, D.R.; Foreman, D. Follicular growth and atresia during the last half of the luteal phase of the guinea pig estrous cycle: Relation to serum progesterone and estradiol levels and utero-ovarian blood flow. Endocrinology 1984, 115, 73-77. [CrossRef] [PubMed]

2. Greiss, F.C., Jr.; Anderson, S.G. Uterine vascular changes during the ovarian cycle. Am. J. Obstet. Gynecol. 1969, 103, 629-640. [CrossRef]

3. Magness, R.R.; Rosenfeld, C.R.; Carr, B.R. Protein kinase $\mathrm{C}$ in uterine and systemic arteries during ovarian cycle and pregnancy. Am. J. Physiol. 1991, 260, E464-E470. [CrossRef] [PubMed]

4. Austin, C.E. Chronic and acute effects of oestrogens on vascular contractility. J. Hypertens. 2000, 18, 1365-1378. [CrossRef]

5. Kostrzewska, A.; Laudanski, T.; Batra, S. Effect of ovarian steroids and diethylstilbestrol on the contractile responses of the human myometrium and intramyometrial arteries. Eur. J. Pharmacol. 1993, 233, 127-134. [CrossRef]

6. Magness, R.R. Maternal cardiovascular and other physiologic responses to the endocrinology of pregnancy. In Endocrinology of Pregnancy; Springer: Berlin/Heidelberg, Germany, 1998; pp. 507-539.

7. Pepe, G.J.; Albrecht, E.D. Actions of placental and fetal adrenal steroid hormones in primate pregnancy. Endocr. Rev. 1995, 16, 608-648. [CrossRef]

8. Reynolds, L.P.; Redmer, D.A. Utero-placental vascular development and placental function. J. Anim. Sci. 1995, 73, 1839-1851. [CrossRef]

9. Magness, R.R.; Rosenfeld, C.R. Local and systemic estradiol-17 beta: Effects on uterine and systemic vasodilation. Am. J. Physiol. 1989, 256, E536-E542. [CrossRef]

10. Reynolds, L.P.; Kirsch, J.D.; Kraft, K.C.; Knutson, D.L.; McClaflin, W.J.; Redmer, D.A. Time-course of the uterine response to estradiol-17beta in ovariectomized ewes: Uterine growth and microvascular development. Biol. Reprod. 1998, 59, 606-612. [CrossRef]

11. Magness, R.; Ford, S. Maternal cardiovascular adaptation and uterine circulation-physiology and pathophysiology. In Stress and Developmental Programming of Health and Disease: Beyond Phenomenology; Nova Science Publishers: Hauppauge, NY, USA, 2014; pp. 341-374.

12. Rosenfeld, C.R. Distribution of cardiac output in ovine pregnancy. Am. J. Physiol. 1977, 232, H231-H235. [CrossRef] [PubMed]

13. Rosenfeld, C.R. The Uterine Circulation; Perinatology Press: Ithaca, NY, USA, 1989.

14. Rosenfeld, C.R.; Morriss, F.H., Jr.; Makowski, E.L.; Meschia, G.; Battaglia, F.C. Circulatory changes in the reproductive tissues of ewes during pregnancy. Gynecol. Investig. 1974, 5, 252-268. [CrossRef] [PubMed]

15. Albrecht, E.D.; Pepe, G.J. Placental steroid hormone biosynthesis in primate pregnancy. Endocr. Rev. 1990, 11, 124-150. [CrossRef]

16. Carnegie, J.A.; Robertson, H.A. Conjugated and unconjugated estrogens in fetal and maternal fluids of the pregnant ewe: A possible role for estrone sulfate during early pregnancy. Biol. Reprod. 1978, 19, $202-211$. [CrossRef] [PubMed]

17. Ford, S.P. Control of uterine and ovarian blood flow throughout the estrous cycle and pregnancy of ewes, sows and cows. J. Anim. Sci. 1982, 55 (Suppl. 2), 32-42. [CrossRef]

18. Markee, J. Rhythmic uterine vascular changes. Am. J. Physiol. 1932, 100, 32-39. [CrossRef]

19. Magness, R.R.; Rosenfeld, C.R. Systemic and uterine responses to alpha-adrenergic stimulation in pregnant and nonpregnant ewes. Am. J. Obstet. Gynecol. 1986, 155, 897-904. [CrossRef]

20. Magness, R.R.; Parker, C.R., Jr.; Rosenfeld, C.R. Systemic and uterine responses to chronic infusion of estradiol-17 beta. Am. J. Physiol. 1993, 265, E690-E698. [CrossRef]

21. Magness, R.R.; Phernetton, T.M.; Zheng, J. Systemic and uterine blood flow distribution during prolonged infusion of 17beta-estradiol. Am. J. Physiol. 1998, 275, H731-H743. [CrossRef]

22. Rosenfeld, C.R.; Chen, C.; Roy, T.; Liu, X. Estrogen selectively up-regulates eNOS and nNOS in reproductive arteries by transcriptional mechanisms. J. Soc. Gynecol. Investig. 2003, 10, 205-215. [CrossRef]

23. Naden, R.P.; Rosenfeld, C.R. Systemic and uterine responsiveness to angiotensin II and norepinephrine in estrogen-treated nonpregnant sheep. Am. J. Obstet. Gynecol. 1985, 153, 417-425. [CrossRef]

24. Killam, A.P.; Rosenfeld, C.R.; Battaglia, F.C.; Makowski, E.L.; Meschia, G. Effect of estrogens on the uterine blood flow of oophorectomized ewes. Am. J. Obstet. Gynecol. 1973, 115, 1045-1052. [CrossRef] 
25. Magness, R.R.; Phernetton, T.M.; Gibson, T.C.; Chen, D.B. Uterine blood flow responses to ICI 182780 in ovariectomized oestradiol-17beta-treated, intact follicular and pregnant sheep. J. Physiol. 2005, 565, 71-83. [CrossRef] [PubMed]

26. Gibson, T.C.; Phernetton, T.M.; Wiltbank, M.C.; Magness, R.R. Development and use of an ovarian synchronization model to study the effects of endogenous estrogen and nitric oxide on uterine blood flow during ovarian cycles in sheep. Biol. Reprod. 2004, 70, 1886-1894. [CrossRef] [PubMed]

27. O'Leary, P.; Boyne, P.; Flett, P.; Beilby, J.; James, I. Longitudinal assessment of changes in reproductive hormones during normal pregnancy. Clin. Chem. 1991, 37, 667-672. [CrossRef] [PubMed]

28. Lang, U.; Baker, R.S.; Braems, G.; Zygmunt, M.; Kunzel, W.; Clark, K.E. Uterine blood flow-A determinant of fetal growth. Eur. J. Obstet. Gynecol. Reprod. Biol. 2003, 110 (Suppl. 1), S55-S61. [CrossRef]

29. Herrera-Garcia, G.; Contag, S. Maternal preeclampsia and risk for cardiovascular disease in offspring. Curr. Hypertens. Rep. 2014, 16, 475. [CrossRef]

30. Barker, D.J.; Bull, A.R.; Osmond, C.; Simmonds, S.J. Fetal and placental size and risk of hypertension in adult life. BMJ 1990, 301, 259-262. [CrossRef]

31. Terragno, N.A.; Terragno, D.A.; Pacholczyk, D.; McGiff, J.C. Prostaglandins and the regulation of uterine blood flow in pregnancy. Nature 1974, 249, 57-58. [CrossRef]

32. Van Buren, G.A.; Yang, D.S.; Clark, K.E. Estrogen-induced uterine vasodilatation is antagonized by L-nitroarginine methyl ester, an inhibitor of nitric oxide synthesis. Am. J. Obstet. Gynecol. 1992, 167, 828-833. [CrossRef]

33. Tschugguel, W.; Stonek, F.; Zhegu, Z.; Dietrich, W.; Schneeberger, C.; Stimpfl, T.; Waldhoer, T.; Vycudilik, W.; Huber, J.C. Estrogen increases endothelial carbon monoxide, heme oxygenase 2, and carbon monoxide-derived cGMP by a receptor-mediated system. J. Clin. Endocrinol. Metab. 2001, 86, 3833-3839. [CrossRef] [PubMed]

34. Burger, N.Z.; Kuzina, O.Y.; Osol, G.; Gokina, N.I. Estrogen replacement enhances EDHF-mediated vasodilation of mesenteric and uterine resistance arteries: Role of endothelial cell $\mathrm{Ca}^{2+}$. Am. J. Physiol. Endocrinol. Metab. 2009, 296, E503-E512. [CrossRef] [PubMed]

35. Rosenfeld, C.R.; Cox, B.E.; Roy, T.; Magness, R.R. Nitric oxide contributes to estrogen-induced vasodilation of the ovine uterine circulation. J. Clin. Investig. 1996, 98, 2158-2166. [CrossRef] [PubMed]

36. Williams, D.J.; Vallance, P.J.; Neild, G.H.; Spencer, J.A.; Imms, F.J. Nitric oxide-mediated vasodilation in human pregnancy. Am. J. Physiol. 1997, 272, H748-H752. [CrossRef]

37. Sheibani, L.; Lechuga, T.J.; Zhang, H.; Hameed, A.; Wing, D.A.; Kumar, S.; Rosenfeld, C.R.; Chen, D.B. Augmented H2S production via cystathionine-beta-synthase upregulation plays a role in pregnancy-associated uterine vasodilation. Biol. Reprod. 2017, 96, 664-672. [CrossRef]

38. Pfaffl, M.W.; Lange, I.G.; Daxenberger, A.; Meyer, H.H. Tissue-specific expression pattern of estrogen receptors (ER): Quantification of ER alpha and ER beta mRNA with real-time RT-PCR. APMIS 2001, 109, 345-355. [CrossRef]

39. Byers, M.J.; Zangl, A.; Phernetton, T.M.; Lopez, G.; Chen, D.B.; Magness, R.R. Endothelial vasodilator production by ovine uterine and systemic arteries: Ovarian steroid and pregnancy control of ERalpha and ERbeta levels. J. Physiol. 2005, 565, 85-99. [CrossRef]

40. Lemmen, J.G.; Broekhof, J.L.; Kuiper, G.G.; Gustafsson, J.A.; van der Saag, P.T.; van der Burg, B. Expression of estrogen receptor alpha and beta during mouse embryogenesis. Mech. Dev. 1999, 81, 163-167. [CrossRef]

41. Shughrue, P.J.; Lane, M.V.; Scrimo, P.J.; Merchenthaler, I. Comparative distribution of estrogen receptor-alpha (ER-alpha) and beta (ER-beta) mRNA in the rat pituitary, gonad, and reproductive tract. Steroids 1998, 63, 498-504. [CrossRef]

42. Maxwell, B.L.; McDonnell, D.P.; Conneely, O.M.; Schulz, T.Z.; Greene, G.L.; O'Malley, B.W. Structural organization and regulation of the chicken estrogen receptor. Mol. Endocrinol. 1987, 1, 25-35. [CrossRef]

43. Weiler, I.J.; Lew, D.; Shapiro, D.J. The Xenopus laevis estrogen receptor: Sequence homology with human and avian receptors and identification of multiple estrogen receptor messenger ribonucleic acids. Mol. Endocrinol. 1987, 1, 355-362. [CrossRef] [PubMed]

44. Nelson, E.R.; Habibi, H.R. Estrogen receptor function and regulation in fish and other vertebrates. Gen. Comp. Endocrinol. 2013, 192, 15-24. [CrossRef] [PubMed]

45. Enmark, E.; Pelto-Huikko, M.; Grandien, K.; Lagercrantz, S.; Lagercrantz, J.; Fried, G.; Nordenskjold, M.; Gustafsson, J.A. Human estrogen receptor beta-gene structure, chromosomal localization, and expression pattern. J. Clin. Endocrinol. Metab. 1997, 82, 4258-4265. [CrossRef] [PubMed] 
46. Gosden, J.R.; Middleton, P.G.; Rout, D. Localization of the human oestrogen receptor gene to chromosome 6q24 $\rightarrow$ q27 by in situ hybridization. Cytogenet. Genome Res. 1986, 43, 218-220. [CrossRef] [PubMed]

47. Heldring, N.; Pike, A.; Andersson, S.; Matthews, J.; Cheng, G.; Hartman, J.; Tujague, M.; Strom, A.; Treuter, E.; Warner, M.; et al. Estrogen receptors: How do they signal and what are their targets. Physiol. Rev. 2007, 87, 905-931. [CrossRef] [PubMed]

48. Kuiper, G.G.; Carlsson, B.; Grandien, K.; Enmark, E.; Haggblad, J.; Nilsson, S.; Gustafsson, J.A. Comparison of the ligand binding specificity and transcript tissue distribution of estrogen receptors alpha and beta. Endocrinology 1997, 138, 863-870. [CrossRef]

49. Wang, Z.; Zhang, X.; Shen, P.; Loggie, B.W.; Chang, Y.; Deuel, T.F. A variant of estrogen receptor-\{alpha\}, hER-\{alpha\}36: Transduction of estrogen- and antiestrogen-dependent membrane-initiated mitogenic signaling. Proc. Natl. Acad. Sci. USA 2006, 103, 9063-9068. [CrossRef]

50. Zou, Y.; Ding, L.; Coleman, M.; Wang, Z. Estrogen receptor-alpha (ER-alpha) suppresses expression of its variant ER-alpha 36. FEBS Lett. 2009, 583, 1368-1374. [CrossRef]

51. Lin, S.L.; Yan, L.Y.; Liang, X.W.; Wang, Z.B.; Wang, Z.Y.; Qiao, J.; Schatten, H.; Sun, Q.Y. A novel variant of ER-alpha, ER-alpha36 mediates testosterone-stimulated ERK and Akt activation in endometrial cancer Hec1A cells. Reprod. Biol. Endocrinol. 2009, 7, 102. [CrossRef]

52. Li, L.; Haynes, M.P.; Bender, J.R. Plasma membrane localization and function of the estrogen receptor alpha variant (ER46) in human endothelial cells. Proc. Natl. Acad. Sci. USA 2003, 100, 4807-4812. [CrossRef]

53. Anamthathmakula, P.; Kyathanahalli, C.; Ingles, J.; Hassan, S.S.; Condon, J.C.; Jeyasuria, P. Estrogen receptor alpha isoform ERdelta7 in myometrium modulates uterine quiescence during pregnancy. EBioMedicine 2019, 39, 520-530. [CrossRef] [PubMed]

54. Stricker, R.; Eberhart, R.; Chevailler, M.C.; Quinn, F.A.; Bischof, P.; Stricker, R. Establishment of detailed reference values for luteinizing hormone, follicle stimulating hormone, estradiol, and progesterone during different phases of the menstrual cycle on the Abbott ARCHITECT analyzer. Clin. Chem. Lab. Med. 2006, 44, 883-887. [CrossRef] [PubMed]

55. Kang, L.; Zhang, X.; Xie, Y.; Tu, Y.; Wang, D.; Liu, Z.; Wang, Z.Y. Involvement of estrogen receptor variant ER-alpha36, not GPR30, in nongenomic estrogen signaling. Mol. Endocrinol. 2010, 24, 709-721. [CrossRef] [PubMed]

56. Hawkins, M.B.; Thornton, J.W.; Crews, D.; Skipper, J.K.; Dotte, A.; Thomas, P. Identification of a third distinct estrogen receptor and reclassification of estrogen receptors in teleosts. Proc. Natl. Acad. Sci. USA 2000, 97, 10751-10756. [CrossRef] [PubMed]

57. Legler, J.; Zeinstra, L.M.; Schuitemaker, F.; Lanser, P.H.; Bogerd, J.; Brouwer, A.; Vethaak, A.D.; De Voogt, P.; Murk, A.J.; Van der Burg, B. Comparison of in vivo and in vitro reporter gene assays for short-term screening of estrogenic activity. Environ. Sci. Technol. 2002, 36, 4410-4415. [CrossRef]

58. Sabo-Attwood, T.; Kroll, K.J.; Denslow, N.D. Differential expression of largemouth bass (Micropterus salmoides) estrogen receptor isotypes alpha, beta, and gamma by estradiol. Mol. Cell. Endocrinol. 2004, 218, 107-118. [CrossRef]

59. Toran-Allerand, C.D. Minireview: A plethora of estrogen receptors in the brain: Where will it end? Endocrinology 2004, 145, 1069-1074. [CrossRef]

60. Rao, B.R. Isolation and characterization of an estrogen binding protein which may integrate the plethora of estrogenic actions in non-reproductive organs. J. Steroid Biochem. Mol. Biol. 1998, 65, 3-41. [CrossRef]

61. Karas, R.H.; Patterson, B.L.; Mendelsohn, M.E. Human vascular smooth muscle cells contain functional estrogen receptor. Circulation 1994, 89, 1943-1950. [CrossRef]

62. Orimo, A.; Inoue, S.; Ouchi, Y.; Orimo, H. Vascular smooth muscle cells possess estrogen receptor and respond to estrogen. Ann. N. Y. Acad. Sci. 1995, 748, 592-594. [CrossRef]

63. Register, T.C.; Adams, M.R. Coronary artery and cultured aortic smooth muscle cells express mRNA for both the classical estrogen receptor and the newly described estrogen receptor beta. J. Steroid Biochem. Mol. Biol. 1998, 64, 187-191. [CrossRef]

64. Thomas, P.; Pang, Y.; Filardo, E.J.; Dong, J. Identity of an estrogen membrane receptor coupled to a G protein in human breast cancer cells. Endocrinology 2005, 146, 624-632. [CrossRef] [PubMed]

65. Batra, S.; Iosif, S. Nuclear estrogen receptors in human uterine arteries. Gynecol. Obstet. Investig. 1987, 24, 250-255. [CrossRef] [PubMed] 
66. Wu, W.X.; Ma, X.H.; Smith, G.C.; Nathanielsz, P.W. Differential distribution of ERalpha and ERbeta mRNA in intrauterine tissues of the pregnant rhesus monkey. Am. J. Physiol. Cell Physiol. 2000, 278, C190-C198. [CrossRef] [PubMed]

67. Chang, K.; Lubo, Z. Review article: Steroid hormones and uterine vascular adaptation to pregnancy. Reprod. Sci. 2008, 15, 336-348. [CrossRef]

68. Reslan, O.M.; Yin, Z.; do Nascimento, G.R.; Khalil, R.A. Subtype-specific estrogen receptor-mediated vasodilator activity in the cephalic, thoracic, and abdominal vasculature of female rat. J. Cardiovasc. Pharmacol. 2013, 62, 26-40. [CrossRef]

69. Mata, K.M.; Li, W.; Reslan, O.M.; Siddiqui, W.T.; Opsasnick, L.A.; Khalil, R.A. Adaptive increases in expression and vasodilator activity of estrogen receptor subtypes in a blood vessel-specific pattern during pregnancy. Am. J. Physiol. Heart Circ. Physiol. 2015, 309, H1679-H1696. [CrossRef]

70. Lechuga, T.J.; Bilg, A.K.; Patel, B.A.; Nguyen, N.A.; Qi, Q.R.; Chen, D.B. Estradiol-17beta stimulates H2 S biosynthesis by ER-dependent CBS and CSE transcription in uterine artery smooth muscle cells in vitro. J. Cell. Physiol. 2019, 234, 9264-9273. [CrossRef]

71. Liao, W.X.; Magness, R.R.; Chen, D.B. Expression of estrogen receptors-alpha and -beta in the pregnant ovine uterine artery endothelial cells in vivo and in vitro. Biol. Reprod. 2005, 72, 530-537. [CrossRef]

72. Scott, P.A.; Tremblay, A.; Brochu, M.; St-Louis, J. Vasorelaxant action of 17-estradiol in rat uterine arteries: Role of nitric oxide synthases and estrogen receptors. Am. J. Physiol. Heart Circ. Physiol. 2007, 293, H3713-H3719. [CrossRef]

73. Hilgers, R.H.; Oparil, S.; Wouters, W.; Coelingh Bennink, H.J. Vasorelaxing effects of estetrol in rat arteries. J. Endocrinol. 2012, 215, 97-106. [CrossRef] [PubMed]

74. Mandala, M. Influence of Estrogens on Uterine Vascular Adaptation in Normal and Preeclamptic Pregnancies. Int. J. Mol. Sci. 2020, 21. [CrossRef] [PubMed]

75. Rubanyi, G.M.; Freay, A.D.; Kauser, K.; Sukovich, D.; Burton, G.; Lubahn, D.B.; Couse, J.F.; Curtis, S.W.; Korach, K.S. Vascular estrogen receptors and endothelium-derived nitric oxide production in the mouse aorta. Gender difference and effect of estrogen receptor gene disruption. J. Clin. Investig. 1997, 99, 2429-2437. [CrossRef] [PubMed]

76. Dupont, S.; Krust, A.; Gansmuller, A.; Dierich, A.; Chambon, P.; Mark, M. Effect of single and compound knockouts of estrogen receptors alpha (ERalpha) and beta (ERbeta) on mouse reproductive phenotypes. Development 2000, 127, 4277-4291. [PubMed]

77. Zhu, Y.; Bian, Z.; Lu, P.; Karas, R.H.; Bao, L.; Cox, D.; Hodgin, J.; Shaul, P.W.; Thoren, P.; Smithies, O.; et al. Abnormal vascular function and hypertension in mice deficient in estrogen receptor beta. Science 2002, 295, 505-508. [CrossRef]

78. Stauffer, S.R.; Coletta, C.J.; Tedesco, R.; Nishiguchi, G.; Carlson, K.; Sun, J.; Katzenellenbogen, B.S.; Katzenellenbogen, J.A. Pyrazole ligands: Structure-affinity/activity relationships and estrogen receptor-alpha-selective agonists. J. Med. Chem. 2000, 43, 4934-4947. [CrossRef]

79. Meyers, M.J.; Sun, J.; Carlson, K.E.; Marriner, G.A.; Katzenellenbogen, B.S.; Katzenellenbogen, J.A. Estrogen receptor-beta potency-selective ligands: Structure-activity relationship studies of diarylpropionitriles and their acetylene and polar analogues. J. Med. Chem. 2001, 44, 4230-4251. [CrossRef]

80. Sun, J.; Huang, Y.R.; Harrington, W.R.; Sheng, S.; Katzenellenbogen, J.A.; Katzenellenbogen, B.S. Antagonists selective for estrogen receptor alpha. Endocrinology 2002, 143, 941-947. [CrossRef]

81. Compton, D.R.; Sheng, S.; Carlson, K.E.; Rebacz, N.A.; Lee, I.Y.; Katzenellenbogen, B.S.; Katzenellenbogen, J.A. Pyrazolo[1,5-a]pyrimidines: Estrogen receptor ligands possessing estrogen receptor beta antagonist activity. J. Med. Chem. 2004, 47, 5872-5893. [CrossRef]

82. Corcoran, J.J.; Nicholson, C.; Sweeney, M.; Charnock, J.C.; Robson, S.C.; Westwood, M.; Taggart, M.J. Human uterine and placental arteries exhibit tissue-specific acute responses to 17beta-estradiol and estrogen-receptor-specific agonists. Mol. Hum. Reprod. 2014, 20, 433-441. [CrossRef]

83. Nicholson, C.J.; Sweeney, M.; Robson, S.C.; Taggart, M.J. Estrogenic vascular effects are diminished by chronological aging. Sci. Rep. 2017, 7, 12153. [CrossRef] [PubMed]

84. Resnik, R.; Killam, A.P.; Battaglia, F.C.; Makowski, E.L.; Meschia, G. The stimulation of uterine blood flow by various estrogens. Endocrinology 1974, 94, 1192-1196. [CrossRef] [PubMed]

85. Resnik, R.; Brink, G.W.; Plumer, M.H. The effect of progesterone on estrogen-induced uterine blood flow. Am. J. Obstet. Gynecol. 1977, 128, 251-254. [CrossRef] 
86. Huckabee, W.E.; Crenshaw, C.; Curet, L.B.; Mann, L.; Barron, D.H. The effect of exogenous oestrogen on the blood flow and oxygen consumption of the uterus of the non-pregnant ewe. Q. J. Exp. Physiol. Cogn. Med. Sci. 1970, 55, 16-24. [CrossRef]

87. Simkiss, K. Influence of large doses of oestrogens on the structure of the bones of some reptiles. Nature 1961, 190, 1217-1218. [CrossRef]

88. Flandroy, L.; Galand, P. Changes in cGMP and cAMP content in the estrogen-stimulated rat uterus: Temporal relationship with other parameters of hormonal stimulation. J. Cyclic Nucleotide Res. 1978, 4, 145-158.

89. Aronica, S.M.; Kraus, W.L.; Katzenellenbogen, B.S. Estrogen action via the cAMP signaling pathway: Stimulation of adenylate cyclase and cAMP-regulated gene transcription. Proc. Natl. Acad. Sci. USA 1994, 91, 8517-8521. [CrossRef]

90. Chen, D.B.; Bird, I.M.; Zheng, J.; Magness, R.R. Membrane estrogen receptor-dependent extracellular signal-regulated kinase pathway mediates acute activation of endothelial nitric oxide synthase by estrogen in uterine artery endothelial cells. Endocrinology 2004, 145, 113-125. [CrossRef]

91. Gu, Q.; Korach, K.S.; Moss, R.L. Rapid action of 17beta-estradiol on kainate-induced currents in hippocampal neurons lacking intracellular estrogen receptors. Endocrinology 1999, 140, 660-666. [CrossRef]

92. Chambliss, K.L.; Yuhanna, I.S.; Mineo, C.; Liu, P.; German, Z.; Sherman, T.S.; Mendelsohn, M.E.; Anderson, R.G.; Shaul, P.W. Estrogen receptor alpha and endothelial nitric oxide synthase are organized into a functional signaling module in caveolae. Circ. Res. 2000, 87, E44-E52. [CrossRef]

93. Pastore, M.B.; Landeros, R.V.; Chen, D.B.; Magness, R.R. Structural analysis of estrogen receptors: Interaction between estrogen receptors and cav-1 within the caveolae. Biol. Reprod. 2019, 100, 495-504. [CrossRef]

94. Pastore, M.B.; Talwar, S.; Conley, M.R.; Magness, R.R. Identification of Differential ER-Alpha Versus ER-Beta Mediated Activation of eNOS in Ovine Uterine Artery Endothelial Cells. Biol. Reprod. 2016, 94, 139. [CrossRef] [PubMed]

95. Carmeci, C.; Thompson, D.A.; Ring, H.Z.; Francke, U.; Weigel, R.J. Identification of a gene (GPR30) with homology to the G-protein-coupled receptor superfamily associated with estrogen receptor expression in breast cancer. Genomics 1997, 45, 607-617. [CrossRef] [PubMed]

96. Mizukami, Y. In vivo functions of GPR30/GPER-1, a membrane receptor for estrogen: From discovery to functions in vivo. Endocr. J. 2010, 57, 101-107. [CrossRef] [PubMed]

97. Revankar, C.M.; Cimino, D.F.; Sklar, L.A.; Arterburn, J.B.; Prossnitz, E.R. A transmembrane intracellular estrogen receptor mediates rapid cell signaling. Science 2005, 307, 1625-1630. [CrossRef] [PubMed]

98. Filardo, E.J.; Quinn, J.A.; Bland, K.I.; Frackelton, A.R., Jr. Estrogen-induced activation of Erk-1 and Erk-2 requires the $\mathrm{G}$ protein-coupled receptor homolog, GPR30, and occurs via trans-activation of the epidermal growth factor receptor through release of HB-EGF. Mol. Endocrinol. 2000, 14, 1649-1660. [CrossRef] [PubMed]

99. Levin, E.R. G protein-coupled receptor 30: Estrogen receptor or collaborator? Endocrinology 2009, 150, 1563-1565. [CrossRef]

100. Alexander, S.P.; Mathie, A.; Peters, J.A. Guide to Receptors and Channels (GRAC), 3rd ed. Br. J. Pharmacol. 2008, 153 (Suppl. 2), S1-S209. [CrossRef]

101. O'Dowd, B.F.; Nguyen, T.; Marchese, A.; Cheng, R.; Lynch, K.R.; Heng, H.H.; Kolakowski, L.F., Jr.; George, S.R. Discovery of three novel G-protein-coupled receptor genes. Genomics 1998, 47, 310-313. [CrossRef]

102. Owman, C.; Blay, P.; Nilsson, C.; Lolait, S.J. Cloning of human cDNA encoding a novel heptahelix receptor expressed in Burkitt's lymphoma and widely distributed in brain and peripheral tissues. Biochem. Biophys. Res. Commun. 1996, 228, 285-292. [CrossRef]

103. Kolkova, Z.; Noskova, V.; Ehinger, A.; Hansson, S.; Casslen, B. G protein-coupled estrogen receptor 1 (GPER, GPR 30) in normal human endometrium and early pregnancy decidua. Mol. Hum. Reprod. 2010, 16, 743-751. [CrossRef] [PubMed]

104. Ylikomi, T.; Vienonen, A.; Ahola, T.M. G protein-coupled receptor 30 down-regulates cofactor expression and interferes with the transcriptional activity of glucocorticoid. Eur. J. Biochem. 2004, 271, 4159-4168. [CrossRef] [PubMed]

105. Isensee, J.; Meoli, L.; Zazzu, V.; Nabzdyk, C.; Witt, H.; Soewarto, D.; Effertz, K.; Fuchs, H.; Gailus-Durner, V.; Busch, D.; et al. Expression pattern of $\mathrm{G}$ protein-coupled receptor 30 in LacZ reporter mice. Endocrinology 2009, 150, 1722-1730. [CrossRef] [PubMed] 
106. Broughton, B.R.; Miller, A.A.; Sobey, C.G. Endothelium-dependent relaxation by G protein-coupled receptor 30 agonists in rat carotid arteries. Am. J. Physiol. Heart Circ. Physiol. 2010, 298, H1055-H1061. [CrossRef] [PubMed]

107. Lindsey, S.H.; Carver, K.A.; Prossnitz, E.R.; Chappell, M.C. Vasodilation in response to the GPR30 agonist G-1 is not different from estradiol in the mRen2.Lewis female rat. J. Cardiovasc. Pharmacol. 2011, 57, 598-603. [CrossRef]

108. Tropea, T.; De Francesco, E.M.; Rigiracciolo, D.; Maggiolini, M.; Wareing, M.; Osol, G.; Mandala, M. Pregnancy Augments G Protein Estrogen Receptor (GPER) Induced Vasodilation in Rat Uterine Arteries via the Nitric Oxide-cGMP Signaling Pathway. PLoS ONE 2015, 10, e0141997. [CrossRef]

109. Haas, E.; Meyer, M.R.; Schurr, U.; Bhattacharya, I.; Minotti, R.; Nguyen, H.H.; Heigl, A.; Lachat, M.; Genoni, M.; Barton, M. Differential effects of 17beta-estradiol on function and expression of estrogen receptor alpha, estrogen receptor beta, and GPR30 in arteries and veins of patients with atherosclerosis. Hypertension 2007, 49, 1358-1363. [CrossRef]

110. Wang, C.; Dehghani, B.; Magrisso, I.J.; Rick, E.A.; Bonhomme, E.; Cody, D.B.; Elenich, L.A.; Subramanian, S.; Murphy, S.J.; Kelly, M.J.; et al. GPR30 contributes to estrogen-induced thymic atrophy. Mol. Endocrinol. 2008, 22, 636-648. [CrossRef]

111. Otto, C.; Fuchs, I.; Kauselmann, G.; Kern, H.; Zevnik, B.; Andreasen, P.; Schwarz, G.; Altmann, H.; Klewer, M.; Schoor, M.; et al. GPR30 does not mediate estrogenic responses in reproductive organs in mice. Biol. Reprod. 2009, 80, 34-41. [CrossRef]

112. Martensson, U.E.; Salehi, S.A.; Windahl, S.; Gomez, M.F.; Sward, K.; Daszkiewicz-Nilsson, J.; Wendt, A.; Andersson, N.; Hellstrand, P.; Grande, P.O.; et al. Deletion of the G protein-coupled receptor 30 impairs glucose tolerance, reduces bone growth, increases blood pressure, and eliminates estradiol-stimulated insulin release in female mice. Endocrinology 2009, 150, 687-698. [CrossRef]

113. Meyer, M.R.; Prossnitz, E.R.; Barton, M. The G protein-coupled estrogen receptor GPER/GPR30 as a regulator of cardiovascular function. Vascul. Pharmacol. 2011, 55, 17-25. [CrossRef] [PubMed]

114. Bologa, C.G.; Revankar, C.M.; Young, S.M.; Edwards, B.S.; Arterburn, J.B.; Kiselyov, A.S.; Parker, M.A.; Tkachenko, S.E.; Savchuck, N.P.; Sklar, L.A.; et al. Virtual and biomolecular screening converge on a selective agonist for GPR30. Nat. Chem. Biol. 2006, 2, 207-212. [CrossRef] [PubMed]

115. Dennis, M.K.; Field, A.S.; Burai, R.; Ramesh, C.; Petrie, W.K.; Bologa, C.G.; Oprea, T.I.; Yamaguchi, Y.; Hayashi, S.; Sklar, L.A.; et al. Identification of a GPER/GPR30 antagonist with improved estrogen receptor counterselectivity. J. Steroid Biochem. Mol. Biol. 2011, 127, 358-366. [CrossRef]

116. Dennis, M.K.; Burai, R.; Ramesh, C.; Petrie, W.K.; Alcon, S.N.; Nayak, T.K.; Bologa, C.G.; Leitao, A.; Brailoiu, E.; Deliu, E.; et al. In vivo effects of a GPR30 antagonist. Nat. Chem. Biol. 2009, 5, 421-427. [CrossRef]

117. Meyer, M.R.; Fredette, N.C.; Howard, T.A.; Hu, C.; Ramesh, C.; Daniel, C.; Amann, K.; Arterburn, J.B.; Barton, M.; Prossnitz, E.R. G protein-coupled estrogen receptor protects from atherosclerosis. Sci. Rep. 2014, 4, 7564. [CrossRef]

118. Wang, H.; Sun, X.; Chou, J.; Lin, M.; Ferrario, C.M.; Zapata-Sudo, G.; Groban, L. Cardiomyocyte-specific deletion of the $G$ protein-coupled estrogen receptor (GPER) leads to left ventricular dysfunction and adverse remodeling: A sex-specific gene profiling analysis. Biochim. Biophys. Acta Mol. Basis Dis. 2017, 1863, 1870-1882. [CrossRef] [PubMed]

119. Lindsey, S.H.; Cohen, J.A.; Brosnihan, K.B.; Gallagher, P.E.; Chappell, M.C. Chronic treatment with the G protein-coupled receptor 30 agonist G-1 decreases blood pressure in ovariectomized mRen2.Lewis rats. Endocrinology 2009, 150, 3753-3758. [CrossRef] [PubMed]

120. Haas, E.; Bhattacharya, I.; Brailoiu, E.; Damjanovic, M.; Brailoiu, G.C.; Gao, X.; Mueller-Guerre, L.; Marjon, N.A.; Gut, A.; Minotti, R.; et al. Regulatory role of G protein-coupled estrogen receptor for vascular function and obesity. Circ. Res. 2009, 104, 288-291. [CrossRef]

121. Mazzuca, M.Q.; Mata, K.M.; Li, W.; Rangan, S.S.; Khalil, R.A. Estrogen receptor subtypes mediate distinct microvascular dilation and reduction in $\left[\mathrm{Ca}^{2+}\right] \mathrm{I}$ in mesenteric microvessels of female rat. J. Pharmacol. Exp. Ther. 2015, 352, 291-304. [CrossRef]

122. Chambliss, K.L.; Shaul, P.W. Rapid activation of endothelial NO synthase by estrogen: Evidence for a steroid receptor fast-action complex (SRFC) in caveolae. Steroids 2002, 67, 413-419. [CrossRef]

123. Galluzzo, P.; Caiazza, F.; Moreno, S.; Marino, M. Role of ERbeta palmitoylation in the inhibition of human colon cancer cell proliferation. Endocr. Relat. Cancer 2007, 14, 153-167. [CrossRef] [PubMed] 
124. Bhatia, M. Hydrogen sulfide as a vasodilator. IUBMB Life 2005, 57, 603-606. [CrossRef] [PubMed]

125. Hurst, A.G.; Goad, D.W.; Mohan, M.; Malayer, J.R. Independent downstream gene expression profiles in the presence of estrogen receptor alpha or beta. Biol. Reprod. 2004, 71, 1252-1261. [CrossRef] [PubMed]

126. Song, R.X.; Barnes, C.J.; Zhang, Z.; Bao, Y.; Kumar, R.; Santen, R.J. The role of Shc and insulin-like growth factor 1 receptor in mediating the translocation of estrogen receptor alpha to the plasma membrane. Proc. Natl. Acad. Sci. USA 2004, 101, 2076-2081. [CrossRef]

127. Marquez, D.C.; Lee, J.; Lin, T.; Pietras, R.J. Epidermal growth factor receptor and tyrosine phosphorylation of estrogen receptor. Endocrine 2001, 16, 73-81. [CrossRef]

128. Pedram, A.; Razandi, M.; Levin, E.R. Nature of functional estrogen receptors at the plasma membrane. Mol. Endocrinol. 2006, 20, 1996-2009. [CrossRef]

129. Pedram, A.; Razandi, M.; Aitkenhead, M.; Hughes, C.C.; Levin, E.R. Integration of the non-genomic and genomic actions of estrogen. Membrane-initiated signaling by steroid to transcription and cell biology. J. Biol. Chem. 2002, 277, 50768-50775. [CrossRef]

130. Kumar, R.; Thompson, E.B. The structure of the nuclear hormone receptors. Steroids 1999, 64, $310-319$. [CrossRef]

131. Kumar, R.; Zakharov, M.N.; Khan, S.H.; Miki, R.; Jang, H.; Toraldo, G.; Singh, R.; Bhasin, S.; Jasuja, R. The dynamic structure of the estrogen receptor. J. Amino. Acids 2011, 2011, 812540. [CrossRef]

132. Le Dily, F.; Beato, M. Signaling by Steroid Hormones in the 3D Nuclear Space. Int. J. Mol. Sci. $2018,19$. [CrossRef]

133. Martini, P.G.; Katzenellenbogen, B.S. Modulation of estrogen receptor activity by selective coregulators. J. Steroid Biochem. Mol. Biol. 2003, 85, 117-122. [CrossRef]

134. Driscoll, M.D.; Sathya, G.; Muyan, M.; Klinge, C.M.; Hilf, R.; Bambara, R.A. Sequence requirements for estrogen receptor binding to estrogen response elements. J. Biol. Chem. 1998, 273, 29321-29330. [CrossRef] [PubMed]

135. Klinge, C.M. Estrogen receptor interaction with estrogen response elements. Nucleic Acids Res. 2001, 29, 2905-2919. [CrossRef] [PubMed]

136. Wang, L.; Andersson, S.; Warner, M.; Gustafsson, J.A. Estrogen receptor (ER)beta knockout mice reveal a role for ERbeta in migration of cortical neurons in the developing brain. Proc. Natl. Acad. Sci. USA 2003, 100, 703-708. [CrossRef]

137. Cowley, S.M.; Hoare, S.; Mosselman, S.; Parker, M.G. Estrogen receptors alpha and beta form heterodimers on DNA. J. Biol. Chem. 1997, 272, 19858-19862. [CrossRef]

138. Kumar, V.; Chambon, P. The estrogen receptor binds tightly to its responsive element as a ligand-induced homodimer. Cell 1988, 55, 145-156. [CrossRef]

139. Charn, T.H.; Liu, E.T.; Chang, E.C.; Lee, Y.K.; Katzenellenbogen, J.A.; Katzenellenbogen, B.S. Genome-wide dynamics of chromatin binding of estrogen receptors alpha and beta: Mutual restriction and competitive site selection. Mol. Endocrinol. 2010, 24, 47-59. [CrossRef]

140. Grober, O.M.; Mutarelli, M.; Giurato, G.; Ravo, M.; Cicatiello, L.; De Filippo, M.R.; Ferraro, L.; Nassa, G.; Papa, M.F.; Paris, O.; et al. Global analysis of estrogen receptor beta binding to breast cancer cell genome reveals an extensive interplay with estrogen receptor alpha for target gene regulation. BMC Genom. 2011, 12, 36. [CrossRef]

141. Sausville, E.; Carney, D.; Battey, J. The human vasopressin gene is linked to the oxytocin gene and is selectively expressed in a cultured lung cancer cell line. J. Biol. Chem. 1985, 260, 10236-10241.

142. Lechuga, T.J.; Qi, Q.R.; Kim, T.; Magness, R.R.; Chen, D.B. E2beta stimulates ovine uterine artery endothelial cell $\mathrm{H} 2 \mathrm{~S}$ production in vitro by estrogen receptor-dependent upregulation of cystathionine beta-synthase and cystathionine gamma-lyase expressiondagger. Biol. Reprod. 2019, 100, 514-522. [CrossRef]

143. Greaves, E.; Collins, F.; Critchley, H.O.; Saunders, P.T. ERbeta-dependent effects on uterine endothelial cells are cell specific and mediated via Sp1. Hum. Reprod. 2013, 28, 2490-2501. [CrossRef] [PubMed]

144. Wang, C.; Mayer, J.A.; Mazumdar, A.; Fertuck, K.; Kim, H.; Brown, M.; Brown, P.H. Estrogen induces c-myc gene expression via an upstream enhancer activated by the estrogen receptor and the AP-1 transcription factor. Mol. Endocrinol. 2011, 25, 1527-1538. [CrossRef] [PubMed]

145. Johnston, S.R.; Lu, B.; Scott, G.K.; Kushner, P.J.; Smith, I.E.; Dowsett, M.; Benz, C.C. Increased activator protein-1 DNA binding and c-Jun NH2-terminal kinase activity in human breast tumors with acquired tamoxifen resistance. Clin. Cancer Res. 1999, 5, 251-256. [PubMed] 
146. Webb, P.; Nguyen, P.; Valentine, C.; Lopez, G.N.; Kwok, G.R.; McInerney, E.; Katzenellenbogen, B.S.; Enmark, E.; Gustafsson, J.A.; Nilsson, S.; et al. The estrogen receptor enhances AP-1 activity by two distinct mechanisms with different requirements for receptor transactivation functions. Mol. Endocrinol. 1999, 13, 1672-1685. [CrossRef] [PubMed]

147. Bajic, V.B.; Tan, S.L.; Chong, A.; Tang, S.; Strom, A.; Gustafsson, J.A.; Lin, C.Y.; Liu, E.T. Dragon ERE Finder version 2: A tool for accurate detection and analysis of estrogen response elements in vertebrate genomes. Nucleic Acids Res. 2003, 31, 3605-3607. [CrossRef]

148. Shaul, P.W.; North, A.J.; Wu, L.C.; Wells, L.B.; Brannon, T.S.; Lau, K.S.; Michel, T.; Margraf, L.R.; Star, R.A. Endothelial nitric oxide synthase is expressed in cultured human bronchiolar epithelium. J. Clin. Investig. 1994, 94, 2231-2236. [CrossRef]

149. Wang, L.; Tang, Z.P.; Zhao, W.; Cong, B.H.; Lu, J.Q.; Tang, X.L.; Li, X.H.; Zhu, X.Y.; Ni, X. MiR-22/Sp-1 Links Estrogens With the Up-Regulation of Cystathionine gamma-Lyase in Myocardium, Which Contributes to Estrogenic Cardioprotection Against Oxidative Stress. Endocrinology 2015, 156, 2124-2137. [CrossRef]

150. O'Lone, R.; Frith, M.C.; Karlsson, E.K.; Hansen, U. Genomic targets of nuclear estrogen receptors. Mol. Endocrinol. 2004, 18, 1859-1875. [CrossRef]

151. Fujimoto, N.; Kitamura, S. Effects of environmental estrogenic chemicals on AP1 mediated transcription with estrogen receptors alpha and beta. J. Steroid Biochem. Mol. Biol. 2004, 88, 53-59. [CrossRef]

152. Lupien, M.; Eeckhoute, J.; Meyer, C.A.; Krum, S.A.; Rhodes, D.R.; Liu, X.S.; Brown, M. Coactivator function defines the active estrogen receptor alpha cistrome. Mol. Cell. Biol. 2009, 29, 3413-3423. [CrossRef]

153. Zaret, K.S.; Carroll, J.S. Pioneer transcription factors: Establishing competence for gene expression. Genes Dev. 2011, 25, 2227-2241. [CrossRef] [PubMed]

154. Filardo, E.J.; Quinn, J.A.; Frackelton, A.R., Jr.; Bland, K.I. Estrogen action via the G protein-coupled receptor, GPR30: Stimulation of adenylyl cyclase and cAMP-mediated attenuation of the epidermal growth factor receptor-to-MAPK signaling axis. Mol. Endocrinol. 2002, 16, 70-84. [CrossRef] [PubMed]

155. Ding, Q.; Gros, R.; Limbird, L.E.; Chorazyczewski, J.; Feldman, R.D. Estradiol-mediated ERK phosphorylation and apoptosis in vascular smooth muscle cells requires GPR 30. Am. J. Physiol. Cell Physiol. 2009, 297, C1178-C1187. [CrossRef] [PubMed]

156. Acconcia, F.; Bocedi, A.; Ascenzi, P.; Marino, M. Does palmitoylation target estrogen receptors to plasma membrane caveolae? IUBMB Life 2003, 55, 33-35. [CrossRef] [PubMed]

157. Acconcia, F.; Ascenzi, P.; Bocedi, A.; Spisni, E.; Tomasi, V.; Trentalance, A.; Visca, P.; Marino, M. Palmitoylation-dependent estrogen receptor alpha membrane localization: Regulation by 17beta-estradiol. Mol. Biol. Cell 2005, 16, 231-237. [CrossRef]

158. Kim, H.P.; Lee, J.Y.; Jeong, J.K.; Bae, S.W.; Lee, H.K.; Jo, I. Nongenomic stimulation of nitric oxide release by estrogen is mediated by estrogen receptor alpha localized in caveolae. Biochem. Biophys. Res. Commun. 1999, 263, 257-262. [CrossRef]

159. Chambliss, K.L.; Yuhanna, I.S.; Anderson, R.G.; Mendelsohn, M.E.; Shaul, P.W. ERbeta has nongenomic action in caveolae. Mol. Endocrinol. 2002, 16, 938-946. [CrossRef]

160. Hisamoto, K.; Ohmichi, M.; Kurachi, H.; Hayakawa, J.; Kanda, Y.; Nishio, Y.; Adachi, K.; Tasaka, K.; Miyoshi, E.; Fujiwara, N.; et al. Estrogen induces the Akt-dependent activation of endothelial nitric-oxide synthase in vascular endothelial cells. J. Biol. Chem. 2001, 276, 3459-3467. [CrossRef]

161. Bird, I.M.; Sullivan, J.A.; Di, T.; Cale, J.M.; Zhang, L.; Zheng, J.; Magness, R.R. Pregnancy-dependent changes in cell signaling underlie changes in differential control of vasodilator production in uterine artery endothelial cells. Endocrinology 2000, 141, 1107-1117. [CrossRef]

162. Bernier, S.G.; Haldar, S.; Michel, T. Bradykinin-regulated interactions of the mitogen-activated protein kinase pathway with the endothelial nitric-oxide synthase. J. Biol. Chem. 2000, 275, 30707-30715. [CrossRef]

163. Wyatt, A.W.; Steinert, J.R.; Wheeler-Jones, C.P.; Morgan, A.J.; Sugden, D.; Pearson, J.D.; Sobrevia, L.; Mann, G.E. Early activation of the p42/p44MAPK pathway mediates adenosine-induced nitric oxide production in human endothelial cells: A novel calcium-insensitive mechanism. FASEB J. 2002, 16, 1584-1594. [CrossRef] [PubMed]

164. Di, T.; Sullivan, J.A.; Magness, R.R.; Zhang, L.; Bird, I.M. Pregnancy-specific enhancement of agonist-stimulated ERK-1/2 signaling in uterine artery endothelial cells increases $\mathrm{Ca}^{2+}$ sensitivity of endothelial nitric oxide synthase as well as cytosolic phospholipase A(2). Endocrinology 2001, 142, 3014-3026. [CrossRef] 
165. Xu, X.; Yan, Q.; Liu, X.; Li, P.; Li, X.; Chen, Y.; Simoncini, T.; Liu, J.; Zhu, D.; Fu, X. 17beta-Estradiol nongenomically induces vascular endothelial $\mathrm{H} 2 \mathrm{~S}$ release by promoting phosphorylation of cystathionine gamma-lyase. J. Biol. Chem. 2019, 294, 15577-15592. [CrossRef] [PubMed]

166. Kim, K.H.; Moriarty, K.; Bender, J.R. Vascular cell signaling by membrane estrogen receptors. Steroids 2008, 73, 864-869. [CrossRef] [PubMed]

167. Marino, M.; Ascenzi, P. Membrane association of estrogen receptor alpha and beta influences 17beta-estradiol-mediated cancer cell proliferation. Steroids 2008, 73, 853-858. [CrossRef]

168. Kato, S.; Endoh, H.; Masuhiro, Y.; Kitamoto, T.; Uchiyama, S.; Sasaki, H.; Masushige, S.; Gotoh, Y.; Nishida, E.; Kawashima, H.; et al. Activation of the estrogen receptor through phosphorylation by mitogen-activated protein kinase. Science 1995, 270, 1491-1494. [CrossRef] [PubMed]

169. Razandi, M.; Pedram, A.; Park, S.T.; Levin, E.R. Proximal events in signaling by plasma membrane estrogen receptors. J. Biol. Chem. 2003, 278, 2701-2712. [CrossRef]

170. Wade, C.B.; Robinson, S.; Shapiro, R.A.; Dorsa, D.M. Estrogen receptor (ER)alpha and ERbeta exhibit unique pharmacologic properties when coupled to activation of the mitogen-activated protein kinase pathway. Endocrinology 2001, 142, 2336-2342. [CrossRef]

171. Ma, Y.; Qiao, X.; Falone, A.E.; Reslan, O.M.; Sheppard, S.J.; Khalil, R.A. Gender-specific reduction in contraction is associated with increased estrogen receptor expression in single vascular smooth muscle cells of female rat. Cell. Physiol. Biochem. 2010, 26, 457-470. [CrossRef]

172. Lindsey, S.H.; Liu, L.; Chappell, M.C. Vasodilation by GPER in mesenteric arteries involves both endothelial nitric oxide and smooth muscle cAMP signaling. Steroids 2014, 81, 99-102. [CrossRef]

173. Ge, X.; Guo, R.; Qiao, Y.; Zhang, Y.; Lei, J.; Wang, X.; Li, L.; Hu, D. The G protein-coupled receptor GPR30 mediates the nontranscriptional effect of estrogen on the activation of PI3K/Akt pathway in endometrial cancer cells. Int. J. Gynecol. Cancer 2013, 23, 52-59. [CrossRef] [PubMed]

174. Vivacqua, A.; Bonofiglio, D.; Recchia, A.G.; Musti, A.M.; Picard, D.; Ando, S.; Maggiolini, M. The G protein-coupled receptor GPR30 mediates the proliferative effects induced by 17beta-estradiol and hydroxytamoxifen in endometrial cancer cells. Mol. Endocrinol. 2006, 20, 631-646. [CrossRef] [PubMed]

175. Filice, E.; Recchia, A.G.; Pellegrino, D.; Angelone, T.; Maggiolini, M.; Cerra, M.C. A new membrane G protein-coupled receptor (GPR30) is involved in the cardiac effects of 17beta-estradiol in the male rat. J. Physiol. Pharmacol. 2009, 60, 3-10.

176. Tian, R.; Wang, Z.; Shi, Z.; Li, D.; Wang, Y.; Zhu, Y.; Lin, W.; Gui, Y.; Zheng, X.L. Differential expression of G-protein-coupled estrogen receptor-30 in human myometrial and uterine leiomyoma smooth muscle. Fertil. Steril. 2013, 99, 256-263. [CrossRef] [PubMed]

177. Levin, E.R. Rapid signaling by steroid receptors. Am. J. Physiol. Regul. Integr. Comp. Physiol. 2008, 295, R1425-R1430. [CrossRef]

178. Chakrabarti, S.; Davidge, S.T. G-protein coupled receptor 30 (GPR30): A novel regulator of endothelial inflammation. PLOS ONE 2012, 7, e52357. [CrossRef]

179. Gao, F.; Ma, X.; Ostmann, A.B.; Das, S.K. GPR30 activation opposes estrogen-dependent uterine growth via inhibition of stromal ERK1/2 and estrogen receptor alpha (ERalpha) phosphorylation signals. Endocrinology 2011, 152, 1434-1447. [CrossRef]

180. Richards, R.G.; DiAugustine, R.P.; Petrusz, P.; Clark, G.C.; Sebastian, J. Estradiol stimulates tyrosine phosphorylation of the insulin-like growth factor-1 receptor and insulin receptor substrate-1 in the uterus. Proc. Natl. Acad. Sci. USA 1996, 93, 12002-12007. [CrossRef]

181. Richards, R.G.; Walker, M.P.; Sebastian, J.; DiAugustine, R.P. Insulin-like growth factor-1 (IGF-1) receptor-insulin receptor substrate complexes in the uterus. Altered signaling response to estradiol in the IGF-1(m/m) mouse. J. Biol. Chem. 1998, 273, 11962-11969. [CrossRef]

182. Sukocheva, O.; Wadham, C.; Holmes, A.; Albanese, N.; Verrier, E.; Feng, F.; Bernal, A.; Derian, C.K.; Ullrich, A.; Vadas, M.A.; et al. Estrogen transactivates EGFR via the sphingosine 1-phosphate receptor Edg-3: The role of sphingosine kinase-1. J. Cell Biol. 2006, 173, 301-310. [CrossRef]

183. Joel, P.B.; Smith, J.; Sturgill, T.W.; Fisher, T.L.; Blenis, J.; Lannigan, D.A. pp90rsk1 regulates estrogen receptor-mediated transcription through phosphorylation of Ser-167. Mol. Cell. Biol. 1998, 18, 1978-1984. [CrossRef] [PubMed] 
184. Sun, M.; Paciga, J.E.; Feldman, R.I.; Yuan, Z.; Coppola, D.; Lu, Y.Y.; Shelley, S.A.; Nicosia, S.V.; Cheng, J.Q. Phosphatidylinositol-3-OH Kinase (PI3K)/AKT2, activated in breast cancer, regulates and is induced by estrogen receptor alpha (ERalpha) via interaction between ERalpha and PI3K. Cancer Res. 2001, 61, 5985-5991. [PubMed]

185. Arnold, S.F.; Melamed, M.; Vorojeikina, D.P.; Notides, A.C.; Sasson, S. Estradiol-binding mechanism and binding capacity of the human estrogen receptor is regulated by tyrosine phosphorylation. Mol. Endocrinol. 1997, 11, 48-53. [CrossRef] [PubMed]

186. Lu, Q.; Schnitzler, G.R.; Vallaster, C.S.; Ueda, K.; Erdkamp, S.; Briggs, C.E.; Iyer, L.K.; Jaffe, I.Z.; Karas, R.H. Unliganded estrogen receptor alpha regulates vascular cell function and gene expression. Mol. Cell. Endocrinol. 2017, 442, 12-23. [CrossRef] [PubMed]

187. Hewitt, S.C.; Winuthayanon, W.; Korach, K.S. What's new in estrogen receptor action in the female reproductive tract. J. Mol. Endocrinol. 2016, 56, R55-R71. [CrossRef]

188. Karas, R.H.; Gauer, E.A.; Bieber, H.E.; Baur, W.E.; Mendelsohn, M.E. Growth factor activation of the estrogen receptor in vascular cells occurs via a mitogen-activated protein kinase-independent pathway. J. Clin. Investig. 1998, 101, 2851-2861. [CrossRef]

189. Mendelsohn, M.E.; Karas, R.H. Rapid progress for non-nuclear estrogen receptor signaling. J. Clin. Investig. 2010, 120, 2277-2279. [CrossRef]

190. Mendelsohn, M.E.; Karas, R.H. The protective effects of estrogen on the cardiovascular system. N. Engl. J. Med. 1999, 340, 1801-1811. [CrossRef]

191. Sentis, S.; Le Romancer, M.; Bianchin, C.; Rostan, M.C.; Corbo, L. Sumoylation of the estrogen receptor alpha hinge region regulates its transcriptional activity. Mol. Endocrinol. 2005, 19, 2671-2684. [CrossRef]

192. Nirmala, P.B.; Thampan, R.V. Ubiquitination of the rat uterine estrogen receptor: Dependence on estradiol. Biochem. Biophys. Res. Commun. 1995, 213, 24-31. [CrossRef]

193. Wang, C.; Fu, M.; Angeletti, R.H.; Siconolfi-Baez, L.; Reutens, A.T.; Albanese, C.; Lisanti, M.P.; Katzenellenbogen, B.S.; Kato, S.; Hopp, T.; et al. Direct acetylation of the estrogen receptor alpha hinge region by p300 regulates transactivation and hormone sensitivity. J. Biol. Chem. 2001, 276, 18375-18383. [CrossRef] [PubMed]

194. Fu, M.; Wang, C.; Zhang, X.; Pestell, R. Nuclear receptor modifications and endocrine cell proliferation. J. Steroid Biochem. Mol. Biol. 2003, 85, 133-138. [CrossRef]

195. Fuqua, S.A.; Wiltschke, C.; Zhang, Q.X.; Borg, A.; Castles, C.G.; Friedrichs, W.E.; Hopp, T.; Hilsenbeck, S.; Mohsin, S.; O'Connell, P.; et al. A hypersensitive estrogen receptor-alpha mutation in premalignant breast lesions. Cancer Res. 2000, 60, 4026-4029. [PubMed]

196. Picard, N.; Caron, V.; Bilodeau, S.; Sanchez, M.; Mascle, X.; Aubry, M.; Tremblay, A. Identification of estrogen receptor beta as a SUMO-1 target reveals a novel phosphorylated sumoylation motif and regulation by glycogen synthase kinase 3beta. Mol. Cell. Biol. 2012, 32, 2709-2721. [CrossRef] [PubMed]

197. Sasaki, M.; Kotcherguina, L.; Dharia, A.; Fujimoto, S.; Dahiya, R. Cytosine-phosphoguanine methylation of estrogen receptors in endometrial cancer. Cancer Res. 2001, 61, 3262-3266. [PubMed]

198. Nothnick, W.B.; Healy, C. Estrogen induces distinct patterns of microRNA expression within the mouse uterus. Reprod. Sci. 2010, 17, 987-994. [CrossRef]

199. Hou, L.; Lu, Y.; Li, Y.; Li, L. MiRNA-451 is a potential biomarker for estrogenicity in mouse uterus. Front. Environ. Sci. Eng. 2014, 8, 99-105. [CrossRef]

200. Perez-Cremades, D.; Mompeon, A.; Vidal-Gomez, X.; Hermenegildo, C.; Novella, S. Role of miRNA in the Regulatory Mechanisms of Estrogens in Cardiovascular Ageing. Oxid. Med. Cell. Longev. 2018, 2018, 6082387. [CrossRef]

201. Williams, K.C.; Renthal, N.E.; Gerard, R.D.; Mendelson, C.R. The microRNA (miR)-199a/214 cluster mediates opposing effects of progesterone and estrogen on uterine contractility during pregnancy and labor. Mol. Endocrinol. 2012, 26, 1857-1867. [CrossRef]

202. Zierau, O.; Helle, J.; Schadyew, S.; Morgenroth, Y.; Bentler, M.; Hennig, A.; Chittur, S.; Tenniswood, M.; Kretzschmar, G. Role of miR-203 in estrogen receptor-mediated signaling in the rat uterus and endometrial carcinoma. J. Cell. Biochem. 2018, 119, 5359-5372. [CrossRef] 
203. Hu, X.Q.; Dasgupta, C.; Xiao, D.; Huang, X.; Yang, S.; Zhang, L. MicroRNA-210 Targets Ten-Eleven Translocation Methylcytosine Dioxygenase 1 and Suppresses Pregnancy-Mediated Adaptation of Large Conductance $\mathrm{Ca}\left({ }^{2+}\right)$-Activated $\left(\mathrm{K}^{+}\right)$Channel Expression and Function in Ovine Uterine Arteries. Hypertension 2017, 70, 601-612. [CrossRef] [PubMed]

204. Pan, Q.; Luo, X.; Toloubeydokhti, T.; Chegini, N. The expression profile of micro-RNA in endometrium and endometriosis and the influence of ovarian steroids on their expression. Mol. Hum. Reprod. 2007, 13, 797-806. [CrossRef] [PubMed]

205. Vidal-Gomez, X.; Perez-Cremades, D.; Mompeon, A.; Dantas, A.P.; Novella, S.; Hermenegildo, C. MicroRNA as Crucial Regulators of Gene Expression in Estradiol-Treated Human Endothelial Cells. Cell. Physiol. Biochem. 2018, 45, 1878-1892. [CrossRef]

206. Dasgupta, C.; Chen, M.; Zhang, H.; Yang, S.; Zhang, L. Chronic hypoxia during gestation causes epigenetic repression of the estrogen receptor-alpha gene in ovine uterine arteries via heightened promoter methylation. Hypertension 2012, 60, 697-704. [CrossRef] [PubMed]

207. Chen, M.; Xiao, D.; Hu, X.Q.; Dasgupta, C.; Yang, S.; Zhang, L. Hypoxia Represses ER-alpha Expression and Inhibits Estrogen-Induced Regulation of $\mathrm{Ca}^{2+}$-Activated $\mathrm{K}^{+}$Channel Activity and Myogenic Tone in Ovine Uterine Arteries: Causal Role of DNA Methylation. Hypertension 2015, 66, 44-51. [CrossRef]

208. Chen, M.; Dasgupta, C.; Xiong, F.; Zhang, L. Epigenetic upregulation of large-conductance $\mathrm{Ca}^{2+}$-activated $\mathrm{K}^{+}$ channel expression in uterine vascular adaptation to pregnancy. Hypertension 2014, 64, 610-618. [CrossRef]

209. Hu, X.Q.; Dasgupta, C.; Chen, M.; Xiao, D.; Huang, X.; Han, L.; Yang, S.; Xu, Z.; Zhang, L. Pregnancy Reprograms Large-Conductance $\mathrm{Ca}\left({ }^{2+}\right)$-Activated $\mathrm{K}^{+}$) Channel in Uterine Arteries: Roles of Ten-Eleven Translocation Methylcytosine Dioxygenase 1-Mediated Active Demethylation. Hypertension 2017, 69, 1181-1191. [CrossRef]

210. Graham, A.; Falcone, T.; Nothnick, W.B. The expression of microRNA-451 in human endometriotic lesions is inversely related to that of macrophage migration inhibitory factor (MIF) and regulates MIF expression and modulation of epithelial cell survival. Hum. Reprod. 2015, 30, 642-652. [CrossRef]

211. Brkic, J.; Dunk, C.; O’Brien, J.; Fu, G.; Nadeem, L.; Wang, Y.L.; Rosman, D.; Salem, M.; Shynlova, O.; Yougbare, I.; et al. MicroRNA-218-5p Promotes Endovascular Trophoblast Differentiation and Spiral Artery Remodeling. Mol. Ther. 2018, 26, 2189-2205. [CrossRef]

212. Myatt, S.S.; Lam, E.W. The emerging roles of forkhead box (Fox) proteins in cancer. Nat. Rev. Cancer 2007, 7, 847-859. [CrossRef]

213. Zhao, W.; Shen, W.W.; Cao, X.M.; Ding, W.Y.; Yan, L.P.; Gao, L.J.; Li, X.L.; Zhong, T.Y. Novel mechanism of miRNA-365-regulated trophoblast apoptosis in recurrent miscarriage. J. Cell. Mol. Med. 2017, 21, 2412-2425. [CrossRef]

214. Fu, G.; Ye, G.; Nadeem, L.; Ji, L.; Manchanda, T.; Wang, Y.; Zhao, Y.; Qiao, J.; Wang, Y.L.; Lye, S.; et al. MicroRNA-376c impairs transforming growth factor-beta and nodal signaling to promote trophoblast cell proliferation and invasion. Hypertension 2013, 61, 864-872. [CrossRef] [PubMed]

215. Wang, W.; Feng, L.; Zhang, H.; Hachy, S.; Satohisa, S.; Laurent, L.C.; Parast, M.; Zheng, J.; Chen, D.B. Preeclampsia up-regulates angiogenesis-associated microRNA (i.e., miR-17, -20a, and -20b) that target ephrin-B2 and EPHB4 in human placenta. J. Clin. Endocrinol. Metab. 2012, 97, E1051-E1059. [CrossRef] [PubMed]

216. Penney, L.L.; Frederick, R.J.; Parker, G.W. 17 beta-estradiol stimulation of uterine blood flow in oophorectomized rabbits with complete inhibition of uterine ribonucleic acid synthesis. Endocrinology 1981, 109, 1672-1676. [CrossRef] [PubMed]

217. Keyes, L.E.; Majack, R.; Dempsey, E.C.; Moore, L.G. Pregnancy stimulation of DNA synthesis and uterine blood flow in the guinea pig. Pediatric Res. 1997, 41, 708-715. [CrossRef]

218. Dickson, W.M.; Bosc, M.J.; Locatelli, A. Effect of estrogen and progesterone on uterine blood flow of castrate sows. Am. J. Physiol. 1969, 217, 1431-1434. [CrossRef]

219. Resnik, R.; Battaglia, F.C.; Makowski, E.L.; Meschia, G. The effect of actinomycin D on estrogen-induced uterine blood flow. Am. J. Obstet. Gynecol. 1975, 122, 273-277. [CrossRef]

220. Rosenfeld, C.R.; Roy, T.; Cox, B.E. Mechanisms modulating estrogen-induced uterine vasodilation. Vascul. Pharmacol. 2002, 38, 115-125. [CrossRef]

221. Furchgott, R.F.; Zawadzki, J.V. The obligatory role of endothelial cells in the relaxation of arterial smooth muscle by acetylcholine. Nature 1980, 288, 373-376. [CrossRef] 
222. Ignarro, L.J.; Buga, G.M.; Wood, K.S.; Byrns, R.E.; Chaudhuri, G. Endothelium-derived relaxing factor produced and released from artery and vein is nitric oxide. Proc. Natl. Acad. Sci. USA 1987, 84, 9265-9269. [CrossRef]

223. Knowles, R.G.; Moncada, S. Nitric oxide synthases in mammals. Biochem. J. 1994, 298 Pt 2, 249-258. [CrossRef]

224. Koshland, D.E., Jr. The molecule of the year. Science 1992, 258, 1861. [CrossRef] [PubMed]

225. Palmer, R.M.; Ferrige, A.G.; Moncada, S. Nitric oxide release accounts for the biological activity of endothelium-derived relaxing factor. Nature 1987, 327, 524-526. [CrossRef] [PubMed]

226. Gross, S.S.; Lane, P. Physiological reactions of nitric oxide and hemoglobin: A radical rethink. Proc. Natl. Acad. Sci. USA 1999, 96, 9967-9969. [CrossRef] [PubMed]

227. Blomberg, L.M.; Blomberg, M.R.; Siegbahn, P.E. A theoretical study of myoglobin working as a nitric oxide scavenger. J. Biol. Inorg. Chem. 2004, 9, 923-935. [CrossRef]

228. Satoh, K.; Ikeda, Y.; Shioda, S.; Tobe, T.; Yoshikawa, T. Edarabone scavenges nitric oxide. Redox Rep. 2002, 7 , 219-222. [CrossRef]

229. Stamler, J.S. S-nitrosothiols and the bioregulatory actions of nitrogen oxides through reactions with thiol groups. Curr. Top. Microbiol. Immunol. 1995, 196, 19-36. [CrossRef]

230. Beckman, J.S.; Beckman, T.W.; Chen, J.; Marshall, P.A.; Freeman, B.A. Apparent hydroxyl radical production by peroxynitrite: Implications for endothelial injury from nitric oxide and superoxide. Proc. Natl. Acad. Sci. USA 1990, 87, 1620-1624. [CrossRef]

231. Tsikas, D.; Denker, K.; Frolich, J.C. Artifactual-free analysis of S-nitrosoglutathione and S-nitroglutathione by neutral-pH, anion-pairing, high-performance liquid chromatography. Study on peroxynitrite-mediated S-nitration of glutathione to S-nitroglutathione under physiological conditions. J. Chromatogr. A 2001, 915, 107-116. [CrossRef]

232. Mayer, B.; Schmidt, K.; Humbert, P.; Bohme, E. Biosynthesis of endothelium-derived relaxing factor: A cytosolic enzyme in porcine aortic endothelial cells $\mathrm{Ca}^{2+}$-dependently converts L-arginine into an activator of soluble guanylyl cyclase. Biochem. Biophys. Res. Commun. 1989, 164, 678-685. [CrossRef]

233. Burstyn, J.N.; Yu, A.E.; Dierks, E.A.; Hawkins, B.K.; Dawson, J.H. Studies of the heme coordination and ligand binding properties of soluble guanylyl cyclase (sGC): Characterization of Fe(II)sGC and Fe(II)sGC(CO) by electronic absorption and magnetic circular dichroism spectroscopies and failure of $\mathrm{CO}$ to activate the enzyme. Biochemistry 1995, 34, 5896-5903. [CrossRef] [PubMed]

234. Francis, S.H.; Busch, J.L.; Corbin, J.D.; Sibley, D. cGMP-dependent protein kinases and cGMP phosphodiesterases in nitric oxide and cGMP action. Pharmacol. Rev. 2010, 62, 525-563. [CrossRef] [PubMed]

235. Ashburn, T.T.; Thor, K.B. Drug repositioning: Identifying and developing new uses for existing drugs. Nat. Rev. Drug Discov. 2004, 3, 673-683. [CrossRef] [PubMed]

236. Goulopoulou, S.; Hannan, J.L.; Matsumoto, T.; Ergul, A.; Webb, R.C. Augmented dilation to nitric oxide in uterine arteries from rats with type 2 diabetes: Implications for vascular adaptations to pregnancy. Am. J. Physiol. Heart Circ. Physiol. 2014, 306, H610-H618. [CrossRef] [PubMed]

237. Magness, R.R.; Shaw, C.E.; Phernetton, T.M.; Zheng, J.; Bird, I.M. Endothelial vasodilator production by uterine and systemic arteries. II. Pregnancy effects on NO synthase expression. Am. J. Physiol. 1997, 272, H1730-H1740. [CrossRef] [PubMed]

238. Vagnoni, K.E.; Shaw, C.E.; Phernetton, T.M.; Meglin, B.M.; Bird, I.M.; Magness, R.R. Endothelial vasodilator production by uterine and systemic arteries. III. Ovarian and estrogen effects on NO synthase. Am. J. Physiol. 1998, 275, H1845-H1856. [CrossRef]

239. Weiner, C.P.; Lizasoain, I.; Baylis, S.A.; Knowles, R.G.; Charles, I.G.; Moncada, S. Induction of calcium-dependent nitric oxide synthases by sex hormones. Proc. Natl. Acad. Sci. USA 1994, 91, 5212-5216. [CrossRef]

240. Magness, R.R.; Rosenfeld, C.R.; Hassan, A.; Shaul, P.W. Endothelial vasodilator production by uterine and systemic arteries. I. Effects of ANG II on PGI2 and NO in pregnancy. Am. J. Physiol. 1996, 270, H1914-H1923. [CrossRef]

241. Nelson, S.H.; Steinsland, O.S.; Wang, Y.; Yallampalli, C.; Dong, Y.L.; Sanchez, J.M. Increased nitric oxide synthase activity and expression in the human uterine artery during pregnancy. Circ. Res. 2000, 87, 406-411. [CrossRef] 
242. Van der Heijden, O.W.; Essers, Y.P.; Fazzi, G.; Peeters, L.L.; De Mey, J.G.; van Eys, G.J. Uterine artery remodeling and reproductive performance are impaired in endothelial nitric oxide synthase-deficient mice. Biol. Reprod. 2005, 72, 1161-1168. [CrossRef]

243. Cadnapaphornchai, M.A.; Ohara, M.; Morris, K.G., Jr.; Knotek, M.; Rogachev, B.; Ladtkow, T.; Carter, E.P.; Schrier, R.W. Chronic NOS inhibition reverses systemic vasodilation and glomerular hyperfiltration in pregnancy. Am. J. Physiol. Renal. Physiol. 2001, 280, F592-F598. [CrossRef] [PubMed]

244. Okamura, T.; Ghoneim, H.A.; Ayajiki, K.; Ammar, E.S.; Toda, N. Mechanisms underlying contraction and relaxation induced by nerve stimulation in monkey uterine arteries. Pharmacology 2000, 61, 251-256. [CrossRef] [PubMed]

245. Kublickiene, K.R.; Cockell, A.P.; Nisell, H.; Poston, L. Role of nitric oxide in the regulation of vascular tone in pressurized and perfused resistance myometrial arteries from term pregnant women. Am. J. Obstet. Gynecol. 1997, 177, 1263-1269. [CrossRef]

246. Yi, F.X.; Magness, R.R.; Bird, I.M. Simultaneous imaging of $\left[\mathrm{Ca}^{2+}\right] \mathrm{i}$ and intracellular NO production in freshly isolated uterine artery endothelial cells: Effects of ovarian cycle and pregnancy. Am. J. Physiol. Regul. Integr. Comp. Physiol. 2005, 288, R140-R148. [CrossRef]

247. Honnens, A.; Weisser, S.; Welter, H.; Einspanier, R.; Bollwein, H. Relationships between uterine blood flow, peripheral sex steroids, expression of endometrial estrogen receptors and nitric oxide synthases during the estrous cycle in mares. J. Reprod. Dev. 2011, 57, 43-48. [CrossRef]

248. Arroyo, J.A.; Anthony, R.V.; Parker, T.A.; Galan, H.L. Differential expression of placental and vascular endothelial nitric oxide synthase in an ovine model of fetal growth restriction. Am. J. Obstet. Gynecol. 2006, 195, 771-777. [CrossRef]

249. Magness, R.R.; Sullivan, J.A.; Li, Y.; Phernetton, T.M.; Bird, I.M. Endothelial vasodilator production by uterine and systemic arteries. VI. Ovarian and pregnancy effects on eNOS and NO(x). Am. J. Physiol. Heart Circ. Physiol. 2001, 280, H1692-H1698. [CrossRef]

250. Zhang, H.H.; Chen, J.C.; Sheibani, L.; Lechuga, T.J.; Chen, D.B. Pregnancy Augments VEGF-Stimulated In Vitro Angiogenesis and Vasodilator $\left(\mathrm{NO}\right.$ and $\left.\mathrm{H}_{2} \mathrm{~S}\right)$ Production in Human Uterine Artery Endothelial Cells. J. Clin. Endocrinol. Metab. 2017, 102, 2382-2393. [CrossRef]

251. Zheng, J.; Bird, I.M.; Chen, D.B.; Magness, R.R. Angiotensin II regulation of ovine fetoplacental artery endothelial functions: Interactions with nitric oxide. J. Physiol. 2005, 565, 59-69. [CrossRef]

252. Bird, I.M.; Zhang, L.; Magness, R.R. Possible mechanisms underlying pregnancy-induced changes in uterine artery endothelial function. Am. J. Physiol. Regul. Integr. Comp. Physiol. 2003, 284, R245-R258. [CrossRef]

253. Bird, I.M. Endothelial nitric oxide synthase activation and nitric oxide function: New light through old windows. J. Endocrinol 2011, 210, 239-241. [CrossRef] [PubMed]

254. Sladek, S.M.; Magness, R.R.; Conrad, K.P. Nitric oxide and pregnancy. Am. J. Physiol. 1997, 272, R441-R463. [CrossRef] [PubMed]

255. Zhang, H.H.; Feng, L.; Wang, W.; Magness, R.R.; Chen, D.B. Estrogen-responsive nitroso-proteome in uterine artery endothelial cells: Role of endothelial nitric oxide synthase and estrogen receptor-beta. J. Cell. Physiol. 2012, 227, 146-159. [CrossRef] [PubMed]

256. Chen, Z.; Yuhanna, I.S.; Galcheva-Gargova, Z.; Karas, R.H.; Mendelsohn, M.E.; Shaul, P.W. Estrogen receptor alpha mediates the nongenomic activation of endothelial nitric oxide synthase by estrogen. J. Clin. Investig. 1999, 103, 401-406. [CrossRef] [PubMed]

257. Hohmann, N.; Xia, N.; Steinkamp-Fenske, K.; Forstermann, U.; Li, H. Estrogen Receptor Signaling and the PI3K/Akt Pathway Are Involved in Betulinic Acid-Induced eNOS Activation. Molecules 2016, 21. [CrossRef] [PubMed]

258. Pastore, M.B.; Jobe, S.O.; Ramadoss, J.; Magness, R.R. Estrogen receptor-alpha and estrogen receptor-beta in the uterine vascular endothelium during pregnancy: Functional implications for regulating uterine blood flow. Semin. Reprod. Med. 2012, 30, 46-61. [CrossRef]

259. Palmer, S.K.; Zamudio, S.; Coffin, C.; Parker, S.; Stamm, E.; Moore, L.G. Quantitative estimation of human uterine artery blood flow and pelvic blood flow redistribution in pregnancy. Obstet. Gynecol. 1992, 80, 1000-1006. [PubMed]

260. Nelson, S.H.; Steinsland, O.S.; Suresh, M.S.; Lee, N.M. Pregnancy augments nitric oxide-dependent dilator response to acetylcholine in the human uterine artery. Hum. Reprod. 1998, 13, 1361-1367. [CrossRef] 
261. Magness, R.R.; Shideman, C.R.; Habermehl, D.A.; Sullivan, J.A.; Bird, I.M. Endothelial vasodilator production by uterine and systemic arteries. V. Effects of ovariectomy, the ovarian cycle, and pregnancy on prostacyclin synthase expression. Prostaglandins Other Lipid Mediat. 2000, 60, 103-118. [CrossRef]

262. Chen, D.B.; Jia, S.; King, A.G.; Barker, A.; Li, S.M.; Mata-Greenwood, E.; Zheng, J.; Magness, R.R. Global protein expression profiling underlines reciprocal regulation of caveolin 1 and endothelial nitric oxide synthase expression in ovariectomized sheep uterine artery by estrogen/progesterone replacement therapy. Biol. Reprod. 2006, 74, 832-838. [CrossRef]

263. Chambliss, K.L.; Shaul, P.W. Estrogen modulation of endothelial nitric oxide synthase. Endocr. Rev. 2002, 23, 665-686. [CrossRef] [PubMed]

264. Sumi, D.; Ignarro, L.J. Estrogen-related receptor alpha 1 up-regulates endothelial nitric oxide synthase expression. Proc. Natl. Acad. Sci. USA 2003, 100, 14451-14456. [CrossRef] [PubMed]

265. Qian, X.X.; Mata-Greenwood, E.; Liao, W.X.; Zhang, H.; Zheng, J.; Chen, D.B. Transcriptional regulation of endothelial nitric oxide synthase expression in uterine artery endothelial cells by c-Jun/AP-1. Mol. Cell. Endocrinol. 2007, 279, 39-51. [CrossRef] [PubMed]

266. Fukao, M.; Mason, H.S.; Britton, F.C.; Kenyon, J.L.; Horowitz, B.; Keef, K.D. Cyclic GMP-dependent protein kinase activates cloned BKCa channels expressed in mammalian cells by direct phosphorylation at serine 1072. J. Biol. Chem. 1999, 274, 10927-10935. [CrossRef]

267. Rosenfeld, C.R.; Cornfield, D.N.; Roy, T. $\mathrm{Ca}\left({ }^{2+}\right)$-activated $\mathrm{K}\left({ }^{+}\right)$channels modulate basal and $\mathrm{E}(2)$ beta-induced rises in uterine blood flow in ovine pregnancy. Am. J. Physiol. Heart Circ. Physiol. 2001, 281, H422-H431. [CrossRef]

268. Rosenfeld, C.R.; Roy, T. Large conductance $\mathrm{Ca}^{2+}$-activated and voltage-activated $\mathrm{K}^{+}$channels contribute to the rise and maintenance of estrogen-induced uterine vasodilation and maintenance of blood pressure. Endocrinology 2012, 153, 6012-6020. [CrossRef]

269. Gokina, N.I.; Bonev, A.D.; Phillips, J.; Gokin, A.P.; Veilleux, K.; Oppenheimer, K.; Goloman, G. Impairment of IKCa channels contributes to uteroplacental endothelial dysfunction in rat diabetic pregnancy. Am. J. Physiol. Heart Circ. Physiol. 2015, 309, H592-H604. [CrossRef]

270. Osol, G.; Mandala, M. Maternal uterine vascular remodeling during pregnancy. Physiology (Bethesda) 2009, 24, 58-71. [CrossRef]

271. Zhang, H.H.; Feng, L.; Livnat, I.; Hoh, J.K.; Shim, J.Y.; Liao, W.X.; Chen, D.B. Estradiol-17beta stimulates specific receptor and endogenous nitric oxide-dependent dynamic endothelial protein S-nitrosylation: Analysis of endothelial nitrosyl-proteome. Endocrinology 2010, 151, 3874-3887. [CrossRef]

272. Chakrabarti, S.; Lekontseva, O.; Peters, A.; Davidge, S.T. 17beta-Estradiol induces protein S-nitrosylation in the endothelium. Cardiovasc. Res. 2010, 85, 796-805. [CrossRef]

273. Hess, D.T.; Matsumoto, A.; Kim, S.O.; Marshall, H.E.; Stamler, J.S. Protein S-nitrosylation: Purview and parameters. Nat. Rev. Mol. Cell. Biol. 2005, 6, 150-166. [CrossRef] [PubMed]

274. Zhang, H.H.; Lechuga, T.J.; Tith, T.; Wang, W.; Wing, D.A.; Chen, D.B. S-nitrosylation of cofilin-1 mediates estradiol-17beta-stimulated endothelial cytoskeleton remodeling. Mol. Endocrinol. 2015, 29, 434-444. [CrossRef] [PubMed]

275. Zhang, H.H.; Wang, W.; Feng, L.; Yang, Y.; Zheng, J.; Huang, L.; Chen, D.B. S-nitrosylation of Cofilin-1 Serves as a Novel Pathway for VEGF-Stimulated Endothelial Cell Migration. J. Cell Physiol. 2015, 230, 406-417. [CrossRef]

276. Ghosh, M.; Song, X.; Mouneimne, G.; Sidani, M.; Lawrence, D.S.; Condeelis, J.S. Cofilin promotes actin polymerization and defines the direction of cell motility. Science 2004, 304, 743-746. [CrossRef]

277. Hale, S.A.; Weger, L.; Mandala, M.; Osol, G. Reduced NO signaling during pregnancy attenuates outward uterine artery remodeling by altering MMP expression and collagen and elastin deposition. Am. J. Physiol. Heart Circ. Physiol. 2011, 301, H1266-H1275. [CrossRef]

278. Stirone, C.; Duckles, S.P.; Krause, D.N.; Procaccio, V. Estrogen increases mitochondrial efficiency and reduces oxidative stress in cerebral blood vessels. Mol. Pharmacol. 2005, 68, 959-965. [CrossRef] [PubMed]

279. Nazarewicz, R.R.; Zenebe, W.J.; Parihar, A.; Larson, S.K.; Alidema, E.; Choi, J.; Ghafourifar, P. Tamoxifen induces oxidative stress and mitochondrial apoptosis via stimulating mitochondrial nitric oxide synthase. Cancer Res. 2007, 67, 1282-1290. [CrossRef]

280. Klinge, C.M. Estrogens regulate life and death in mitochondria. J. Bioenerg. Biomembr. 2017, 49, 307-324. [CrossRef] 
281. Klinge, C.M. Estrogenic control of mitochondrial function and biogenesis. J. Cell. Biochem. 2008, 105, 1342-1351. [CrossRef]

282. Satohisa, S.; Zhang, H.H.; Feng, L.; Yang, Y.Y.; Huang, L.; Chen, D.B. Endogenous NO upon estradiol-17beta stimulation and NO donor differentially regulate mitochondrial S-nitrosylation in endothelial cells. Endocrinology 2014, 155, 3005-3016. [CrossRef]

283. Haldane, J. The Relation of the Action of Carbonic Oxide to Oxygen Tension. J. Physiol. 1895, 18, $201-217$. [CrossRef] [PubMed]

284. Von Burg, R. Toxicology update: Carbon monoxide. J. Appl. Toxicol. 1999, 19, 379-386. [CrossRef]

285. Langston, P.; Gorman, D.; Runciman, W.; Upton, R. The effect of carbon monoxide on oxygen metabolism in the brains of awake sheep. Toxicology 1996, 114, 223-232. [CrossRef]

286. Sjostrand, T. Endogenous formation of carbon monoxide; the CO concentration in the inspired and expired air of hospital patients. Acta Physiol. Scand. 1951, 22, 137-141. [CrossRef]

287. Verma, A.; Hirsch, D.J.; Glatt, C.E.; Ronnett, G.V.; Snyder, S.H. Carbon monoxide: A putative neural messenger. Science 1993, 259, 381-384. [CrossRef]

288. Suematsu, M.; Kashiwagi, S.; Sano, T.; Goda, N.; Shinoda, Y.; Ishimura, Y. Carbon monoxide as an endogenous modulator of hepatic vascular perfusion. Biochem. Biophys. Res. Commun. 1994, 205, 1333-1337. [CrossRef]

289. Otterbein, L.E.; Bach, F.H.; Alam, J.; Soares, M.; Tao Lu, H.; Wysk, M.; Davis, R.J.; Flavell, R.A.; Choi, A.M. Carbon monoxide has anti-inflammatory effects involving the mitogen-activated protein kinase pathway. Nat. Med. 2000, 6, 422-428. [CrossRef]

290. Brouard, S.; Otterbein, L.E.; Anrather, J.; Tobiasch, E.; Bach, F.H.; Choi, A.M.; Soares, M.P. Carbon monoxide generated by heme oxygenase 1 suppresses endothelial cell apoptosis. J. Exp. Med. 2000, 192, 1015-1026. [CrossRef]

291. Zhang, X.; Shan, P.; Otterbein, L.E.; Alam, J.; Flavell, R.A.; Davis, R.J.; Choi, A.M.; Lee, P.J. Carbon monoxide inhibition of apoptosis during ischemia-reperfusion lung injury is dependent on the p38 mitogen-activated protein kinase pathway and involves caspase 3. J. Biol. Chem. 2003, 278, 1248-1258. [CrossRef]

292. Morita, T.; Mitsialis, S.A.; Koike, H.; Liu, Y.; Kourembanas, S. Carbon monoxide controls the proliferation of hypoxic vascular smooth muscle cells. J. Biol. Chem. 1997, 272, 32804-32809. [CrossRef]

293. Maines, M.D. The heme oxygenase system: A regulator of second messenger gases. Annu. Rev. Pharmacol. Toxicol. 1997, 37, 517-554. [CrossRef] [PubMed]

294. Keyse, S.M.; Tyrrell, R.M. Heme oxygenase is the major 32-kDa stress protein induced in human skin fibroblasts by UVA radiation, hydrogen peroxide, and sodium arsenite. Proc. Natl. Acad. Sci. USA 1989, 86, 99-103. [CrossRef] [PubMed]

295. Durante, W.; Christodoulides, N.; Cheng, K.; Peyton, K.J.; Sunahara, R.K.; Schafer, A.I. cAMP induces heme oxygenase-1 gene expression and carbon monoxide production in vascular smooth muscle. Am. J. Physiol 1997, 273, H317-H323. [CrossRef] [PubMed]

296. Kourembanas, S.; Morita, T.; Liu, Y.; Christou, H. Mechanisms by which oxygen regulates gene expression and cell-cell interaction in the vasculature. Kidney Int. 1997, 51, 438-443. [CrossRef] [PubMed]

297. Tenhunen, R.; Marver, H.S.; Schmid, R. Microsomal heme oxygenase. Characterization of the enzyme. J. Biol. Chem. 1969, 244, 6388-6394.

298. Welch, W.J.; Feramisco, J.R. Purification of the major mammalian heat shock proteins. J. Biol. Chem. 1982, 257, 14949-14959.

299. Acevedo, C.H.; Ahmed, A. Hemeoxygenase-1 inhibits human myometrial contractility via carbon monoxide and is upregulated by progesterone during pregnancy. J. Clin. Investig. 1998, 101, 949-955. [CrossRef]

300. Zhao, H.; Wong, R.J.; Kalish, F.S.; Nayak, N.R.; Stevenson, D.K. Effect of heme oxygenase-1 deficiency on placental development. Placenta 2009, 30, 861-868. [CrossRef]

301. Zhao, H.; Azuma, J.; Kalish, F.; Wong, R.J.; Stevenson, D.K. Maternal heme oxygenase 1 regulates placental vasculature development via angiogenic factors in mice. Biol. Reprod. 2011, 85, 1005-1012. [CrossRef]

302. Meyer, N.; Langwisch, S.; Scharm, M.; Zenclussen, A.C. Using ultrasound to define the time point of intrauterine growth retardation in a mouse model of heme oxygenase-1 deficiency. Biol. Reprod. 2020. [CrossRef]

303. Vile, G.F.; Basu-Modak, S.; Waltner, C.; Tyrrell, R.M. Heme oxygenase 1 mediates an adaptive response to oxidative stress in human skin fibroblasts. Proc. Natl. Acad. Sci. USA 1994, 91, 2607-2610. [CrossRef] [PubMed] 
304. Zakhary, R.; Gaine, S.P.; Dinerman, J.L.; Ruat, M.; Flavahan, N.A.; Snyder, S.H. Heme oxygenase 2: Endothelial and neuronal localization and role in endothelium-dependent relaxation. Proc. Natl. Acad. Sci. USA 1996, 93, 795-798. [CrossRef] [PubMed]

305. Christodoulides, N.; Durante, W.; Kroll, M.H.; Schafer, A.I. Vascular smooth muscle cell heme oxygenases generate guanylyl cyclase-stimulatory carbon monoxide. Circulation 1995, 91, 2306-2309. [CrossRef] [PubMed]

306. Vreman, H.J.; Wong, R.J.; Harmatz, P.; Fanaroff, A.A.; Berman, B.; Stevenson, D.K. Validation of the Natus CO-Stat End Tidal Breath Analyzer in children and adults. J. Clin. Monit. Comput. 1999, 15, 421-427. [CrossRef]

307. Cook, M.N.; Nakatsu, K.; Marks, G.S.; McLaughlin, B.E.; Vreman, H.J.; Stevenson, D.K.; Brien, J.F. Heme oxygenase activity in the adult rat aorta and liver as measured by carbon monoxide formation. Can. J. Physiol. Pharmacol. 1995, 73, 515-518. [CrossRef]

308. Lee, P.J.; Alam, J.; Sylvester, S.L.; Inamdar, N.; Otterbein, L.; Choi, A.M. Regulation of heme oxygenase-1 expression in vivo and in vitro in hyperoxic lung injury. Am. J. Respir. Cell Mol. Biol. 1996, 14, 556-568. [CrossRef]

309. Otterbein, L.E.; Zuckerbraun, B.S.; Haga, M.; Liu, F.; Song, R.; Usheva, A.; Stachulak, C.; Bodyak, N.; Smith, R.N.; Csizmadia, E.; et al. Carbon monoxide suppresses arteriosclerotic lesions associated with chronic graft rejection and with balloon injury. Nat. Med. 2003, 9, 183-190. [CrossRef]

310. Sato, K.; Balla, J.; Otterbein, L.; Smith, R.N.; Brouard, S.; Lin, Y.; Csizmadia, E.; Sevigny, J.; Robson, S.C.; Vercellotti, G.; et al. Carbon monoxide generated by heme oxygenase-1 suppresses the rejection of mouse-to-rat cardiac transplants. J. Immunol. 2001, 166, 4185-4194. [CrossRef]

311. Yamashita, K.; McDaid, J.; Ollinger, R.; Tsui, T.Y.; Berberat, P.O.; Usheva, A.; Csizmadia, E.; Smith, R.N.; Soares, M.P.; Bach, F.H. Biliverdin, a natural product of heme catabolism, induces tolerance to cardiac allografts. FASEB J. 2004, 18, 765-767. [CrossRef]

312. Leffler, C.W.; Parfenova, H.; Jaggar, J.H. Carbon monoxide as an endogenous vascular modulator. Am. J. Physiol. Heart Circ. Physiol. 2011, 301, H1-H11. [CrossRef]

313. Leffler, C.W.; Nasjletti, A.; Yu, C.; Johnson, R.A.; Fedinec, A.L.; Walker, N. Carbon monoxide and cerebral microvascular tone in newborn pigs. Am. J. Physiol. 1999, 276, H1641-H1646. [CrossRef] [PubMed]

314. Leffler, C.W.; Parfenova, H.; Jaggar, J.H.; Wang, R. Carbon monoxide and hydrogen sulfide: Gaseous messengers in cerebrovascular circulation. J. Appl. Physiol. 2006, 100, 1065-1076. [CrossRef] [PubMed]

315. Adin, C.A.; Croker, B.P.; Agarwal, A. Protective effects of exogenous bilirubin on ischemia-reperfusion injury in the isolated, perfused rat kidney. Am. J. Physiol. Renal. Physiol. 2005, 288, F778-F784. [CrossRef] [PubMed]

316. Zhang, T.; Liang, X.; Shi, L.; Wang, L.; Chen, J.; Kang, C.; Zhu, J.; Mi, M. Estrogen receptor and PI3K/Akt signaling pathway involvement in S-(-)equol-induced activation of Nrf2/ARE in endothelial cells. PLoS ONE 2013, 8, e79075. [CrossRef] [PubMed]

317. Kreiser, D.; Baum, M.; Seidman, D.S.; Fanaroff, A.; Shah, D.; Hendler, I.; Stevenson, D.K.; Schiff, E.; Druzin, M.L. End tidal carbon monoxide levels are lower in women with gestational hypertension and pre-eclampsia. J. Perinatol. 2004, 24, 213-217. [CrossRef] [PubMed]

318. Ramazzini, B. De morbis artificum diatriba [diseases of workers]. 1713. Am. J. Public Health 2001, 91, 1380-1382. [CrossRef] [PubMed]

319. Abe, K.; Kimura, H. The possible role of hydrogen sulfide as an endogenous neuromodulator. J. Neurosci. 1996, 16, 1066-1071. [CrossRef] [PubMed]

320. Wang, R. Physiological implications of hydrogen sulfide: A whiff exploration that blossomed. Physiol. Rev. 2012, 92, 791-896. [CrossRef]

321. Hosoki, R.; Matsuki, N.; Kimura, H. The possible role of hydrogen sulfide as an endogenous smooth muscle relaxant in synergy with nitric oxide. Biochem. Biophys. Res. Commun. 1997, 237, 527-531. [CrossRef]

322. Stipanuk, M.H.; Beck, P.W. Characterization of the enzymic capacity for cysteine desulphhydration in liver and kidney of the rat. Biochem. J. 1982, 206, 267-277. [CrossRef]

323. Swaroop, M.; Bradley, K.; Ohura, T.; Tahara, T.; Roper, M.D.; Rosenberg, L.E.; Kraus, J.P. Rat cystathionine beta-synthase. Gene organization and alternative splicing. J. Biol. Chem. 1992, 267, 11455-11461. [PubMed]

324. Chiku, T.; Padovani, D.; Zhu, W.; Singh, S.; Vitvitsky, V.; Banerjee, R. $\mathrm{H}_{2} \mathrm{~S}$ biogenesis by human cystathionine gamma-lyase leads to the novel sulfur metabolites lanthionine and homolanthionine and is responsive to the grade of hyperhomocysteinemia. J. Biol. Chem. 2009, 284, 11601-11612. [CrossRef] [PubMed] 
325. Singh, S.; Padovani, D.; Leslie, R.A.; Chiku, T.; Banerjee, R. Relative contributions of cystathionine beta-synthase and gamma-cystathionase to $\mathrm{H}_{2} \mathrm{~S}$ biogenesis via alternative trans-sulfuration reactions. J. Biol. Chem. 2009, 284, 22457-22466. [CrossRef] [PubMed]

326. Gadalla, M.M.; Snyder, S.H. Hydrogen sulfide as a gasotransmitter. J. Neurochem. 2010, 113, 14-26. [CrossRef]

327. Mustafa, A.K.; Gadalla, M.M.; Snyder, S.H. Signaling by gasotransmitters. Sci. Signal. 2009, 2, re2. [CrossRef]

328. Shibuya, N.; Mikami, Y.; Kimura, Y.; Nagahara, N.; Kimura, H. Vascular endothelium expresses 3-mercaptopyruvate sulfurtransferase and produces hydrogen sulfide. J. Biochem. 2009, 146, 623-626. [CrossRef]

329. Lowicka, E.; Beltowski, J. Hydrogen sulfide (H2S)—The third gas of interest for pharmacologists. Pharmacol. Rep. 2007, 59, 4-24. [PubMed]

330. Wang, R. Two's company, three's a crowd: $\mathrm{Can}_{2} \mathrm{H}_{2} \mathrm{~S}$ be the third endogenous gaseous transmitter? FASEB J. 2002, 16, 1792-1798. [CrossRef]

331. Zhao, W.; Zhang, J.; Lu, Y.; Wang, R. The vasorelaxant effect of $\left.\mathrm{H}_{(2}\right) \mathrm{S}$ as a novel endogenous gaseous K(ATP) channel opener. EMBO J. 2001, 20, 6008-6016. [CrossRef]

332. Kondo, K.; Bhushan, S.; King, A.L.; Prabhu, S.D.; Hamid, T.; Koenig, S.; Murohara, T.; Predmore, B.L.; Gojon, G., Sr.; Gojon, G., Jr.; et al. $\mathrm{H}(2) S$ protects against pressure overload-induced heart failure via upregulation of endothelial nitric oxide synthase. Circulation 2013, 127, 1116-1127. [CrossRef]

333. Jackson, M.R.; Melideo, S.L.; Jorns, M.S. Human sulfide: Quinone oxidoreductase catalyzes the first step in hydrogen sulfide metabolism and produces a sulfane sulfur metabolite. Biochemistry 2012, 51, 6804-6815. [CrossRef] [PubMed]

334. Olson, K.R. Hydrogen sulfide as an oxygen sensor. Clin. Chem. Lab. Med. 2013, 51, 623-632. [CrossRef] [PubMed]

335. Cuevasanta, E.; Zeida, A.; Carballal, S.; Wedmann, R.; Morzan, U.N.; Trujillo, M.; Radi, R.; Estrin, D.A.; Filipovic, M.R.; Alvarez, B. Insights into the mechanism of the reaction between hydrogen sulfide and peroxynitrite. Free Radic. Biol. Med. 2015, 80, 93-100. [CrossRef] [PubMed]

336. Gao, X.H.; Krokowski, D.; Guan, B.J.; Bederman, I.; Majumder, M.; Parisien, M.; Diatchenko, L.; Kabil, O.; Willard, B.; Banerjee, R.; et al. Quantitative $\mathrm{H}_{2} \mathrm{~S}$-mediated protein sulfhydration reveals metabolic reprogramming during the integrated stress response. eLife 2015, 4, e10067. [CrossRef] [PubMed]

337. Mustafa, A.K.; Sikka, G.; Gazi, S.K.; Steppan, J.; Jung, S.M.; Bhunia, A.K.; Barodka, V.M.; Gazi, F.K.; Barrow, R.K.; Wang, R.; et al. Hydrogen sulfide as endothelium-derived hyperpolarizing factor sulfhydrates potassium channels. Circ. Res. 2011, 109, 1259-1268. [CrossRef]

338. Wang, K.; Ahmad, S.; Cai, M.; Rennie, J.; Fujisawa, T.; Crispi, F.; Baily, J.; Miller, M.R.; Cudmore, M.; Hadoke, P.W.; et al. Dysregulation of hydrogen sulfide producing enzyme cystathionine gamma-lyase contributes to maternal hypertension and placental abnormalities in preeclampsia. Circulation 2013, 127, 2514-2522. [CrossRef]

339. Badiei, A.; Chambers, S.T.; Gaddam, R.R.; Bhatia, M. Cystathionine-gamma-lyase gene silencing with siRNA in monocytes/macrophages attenuates inflammation in cecal ligation and puncture-induced sepsis in the mouse. J. Biosci. 2016, 41, 87-95. [CrossRef]

340. Liu, Y.; Deng, Y.; Liu, H.; Yin, C.; Li, X.; Gong, Q. Hydrogen sulfide ameliorates learning memory impairment in APP/PS1 transgenic mice: A novel mechanism mediated by the activation of Nrf2. Pharmacol. Biochem. Behav. 2016, 150-151, 207-216. [CrossRef]

341. Burgoyne, J.R.; Madhani, M.; Cuello, F.; Charles, R.L.; Brennan, J.P.; Schroder, E.; Browning, D.D.; Eaton, P. Cysteine redox sensor in PKGIa enables oxidant-induced activation. Science 2007, 317, 1393-1397. [CrossRef]

342. Neo, B.H.; Kandhi, S.; Ahmad, M.; Wolin, M.S. Redox regulation of guanylate cyclase and protein kinase G in vascular responses to hypoxia. Respir. Physiol. Neurobiol. 2010, 174, 259-264. [CrossRef]

343. Stubbert, D.; Prysyazhna, O.; Rudyk, O.; Scotcher, J.; Burgoyne, J.R.; Eaton, P. Protein kinase G Ialpha oxidation paradoxically underlies blood pressure lowering by the reductant hydrogen sulfide. Hypertension 2014, 64, 1344-1351. [CrossRef] [PubMed]

344. Zhao, K.; Ju, Y.; Li, S.; Altaany, Z.; Wang, R.; Yang, G. S-sulfhydration of MEK1 leads to PARP-1 activation and DNA damage repair. EMBO Rep. 2014, 15, 792-800. [CrossRef] [PubMed]

345. Fukami, K.; Kawabata, A. Hydrogen sulfide and neuronal differentiation: Focus on $\mathrm{Ca}^{2+}$ channels. Nitric Oxide 2015, 46, 50-54. [CrossRef] [PubMed] 
346. Ping, N.N.; Li, S.; Mi, Y.N.; Cao, L.; Cao, Y.X. Hydrogen sulphide induces vasoconstriction of rat coronary artery via activation of $\mathrm{Ca}\left({ }^{2+}\right)$ influx. Acta Physiol. (Oxf.) 2015, 214, 88-96. [CrossRef]

347. Zhang, W.; Xu, C.; Yang, G.; Wu, L.; Wang, R. Interaction of $\mathrm{H}_{2} \mathrm{~S}$ with Calcium Permeable Channels and Transporters. Oxid. Med. Cell. Longev. 2015, 2015, 323269. [CrossRef]

348. Lee, S.W.; Cheng, Y.; Moore, P.K.; Bian, J.S. Hydrogen sulphide regulates intracellular pH in vascular smooth muscle cells. Biochem. Biophys. Res. Commun. 2007, 358, 1142-1147. [CrossRef]

349. Sun, Y.G.; Cao, Y.X.; Wang, W.W.; Ma, S.F.; Yao, T.; Zhu, Y.C. Hydrogen sulphide is an inhibitor of L-type calcium channels and mechanical contraction in rat cardiomyocytes. Cardiovasc. Res. 2008, 79, 632-641. [CrossRef]

350. Malekova, L.; Krizanova, O.; Ondrias, $\mathrm{K} . \mathrm{H}(2) \mathrm{S}$ and $\left.\mathrm{HS}^{-}\right)$donor NaHS inhibits intracellular chloride channels. Gen. Physiol. Biophys. 2009, 28, 190-194. [CrossRef]

351. Yang, G.; Wu, L.; Jiang, B.; Yang, W.; Qi, J.; Cao, K.; Meng, Q.; Mustafa, A.K.; Mu, W.; Zhang, S.; et al. $\mathrm{H}_{2} \mathrm{~S}$ as a physiologic vasorelaxant: Hypertension in mice with deletion of cystathionine gamma-lyase. Science 2008, 322, 587-590. [CrossRef]

352. Jackson-Weaver, O.; Osmond, J.M.; Riddle, M.A.; Naik, J.S.; Gonzalez Bosc, L.V.; Walker, B.R.; Kanagy, N.L. Hydrogen sulfide dilates rat mesenteric arteries by activating endothelial large-conductance $\mathrm{Ca}\left({ }^{2+}\right)$-activated $\mathrm{K}\left({ }^{+}\right)$channels and smooth muscle $\mathrm{Ca}\left({ }^{2+}\right)$ sparks. Am. J. Physiol. Heart Circ. Physiol. 2013, 304, H1446-H1454. [CrossRef]

353. Donovan, J.; Wong, P.S.; Roberts, R.E.; Garle, M.J.; Alexander, S.P.H.; Dunn, W.R.; Ralevic, V. A critical role for cystathionine-beta-synthase in hydrogen sulfide-mediated hypoxic relaxation of the coronary artery. Vascul. Pharmacol. 2017, 93-95, 20-32. [CrossRef] [PubMed]

354. Cheng, Y.; Ndisang, J.F.; Tang, G.; Cao, K.; Wang, R. Hydrogen sulfide-induced relaxation of resistance mesenteric artery beds of rats. Am. J. Physiol. Heart Circ. Physiol. 2004, 287, H2316-H2323. [CrossRef] [PubMed]

355. Tang, G.; Wu, L.; Liang, W.; Wang, R. Direct stimulation of K(ATP) channels by exogenous and endogenous hydrogen sulfide in vascular smooth muscle cells. Mol. Pharmacol. 2005, 68, 1757-1764. [CrossRef] [PubMed]

356. Papapetropoulos, A.; Pyriochou, A.; Altaany, Z.; Yang, G.; Marazioti, A.; Zhou, Z.; Jeschke, M.G.; Branski, L.K.; Herndon, D.N.; Wang, R.; et al. Hydrogen sulfide is an endogenous stimulator of angiogenesis. Proc. Natl. Acad. Sci. USA 2009, 106, 21972-21977. [CrossRef]

357. Naik, J.S.; Osmond, J.M.; Walker, B.R.; Kanagy, N.L. Hydrogen sulfide-induced vasodilation mediated by endothelial TRPV4 channels. Am. J. Physiol. Heart Circ. Physiol. 2016, 311, H1437-H1444. [CrossRef]

358. Kang, M.; Hashimoto, A.; Gade, A.; Akbarali, H.I. Interaction between hydrogen sulfide-induced sulfhydration and tyrosine nitration in the KATP channel complex. Am. J. Physiol. Gastrointest. Liver Physiol. 2015, 308, G532-G539. [CrossRef]

359. Liu, D.H.; Huang, X.; Meng, X.M.; Zhang, C.M.; Lu, H.L.; Kim, Y.C.; Xu, W.X. Exogenous $\mathrm{H}_{2} \mathrm{~S}$ enhances mice gastric smooth muscle tension through S-sulfhydration of KV 4.3, mediating the inhibition of the voltage-dependent potassium current. Neurogastroenterol. Motil. 2014, 26, 1705-1716. [CrossRef]

360. Itoh, H.; Bird, I.M.; Nakao, K.; Magness, R.R. Pregnancy increases soluble and particulate guanylate cyclases and decreases the clearance receptor of natriuretic peptides in ovine uterine, but not systemic, arteries. Endocrinology 1998, 139, 3329-3341. [CrossRef]

361. Hu, X.Q.; Xiao, D.; Zhu, R.; Huang, X.; Yang, S.; Wilson, S.; Zhang, L. Pregnancy upregulates large-conductance $\mathrm{Ca}^{2+}$-activated $\mathrm{K}^{+}$channel activity and attenuates myogenic tone in uterine arteries. Hypertension 2011, 58, 1132-1139. [CrossRef]

362. Xiao, D.; Longo, L.D.; Zhang, L. Role of KATP and L-type $\mathrm{Ca}^{2+}$ channel activities in regulation of ovine uterine vascular contractility: Effect of pregnancy and chronic hypoxia. Am. J. Obstet. Gynecol. 2010, 203, 596.e6. [CrossRef]

363. Khan, L.H.; Rosenfeld, C.R.; Liu, X.T.; Magness, R.R. Regulation of the cGMP-cPKG pathway and large-conductance $\mathrm{Ca}^{2+}$-activated $\mathrm{K}^{+}$channels in uterine arteries during the ovine ovarian cycle. Am. J. Physiol. Endocrinol. Metab. 2010, 298, E222-E228. [CrossRef] [PubMed]

364. Wang, M.J.; Cai, W.J.; Li, N.; Ding, Y.J.; Chen, Y.; Zhu, Y.C. The hydrogen sulfide donor NaHS promotes angiogenesis in a rat model of hind limb ischemia. Antioxid. Redox Signal. 2010, 12, 1065-1077. [CrossRef] [PubMed] 
365. Szabo, C.; Papapetropoulos, A. Hydrogen sulphide and angiogenesis: Mechanisms and applications. Br. J. Pharmacol. 2011, 164, 853-865. [CrossRef] [PubMed]

366. Polhemus, D.J.; Kondo, K.; Bhushan, S.; Bir, S.C.; Kevil, C.G.; Murohara, T.; Lefer, D.J.; Calvert, J.W. Hydrogen sulfide attenuates cardiac dysfunction after heart failure via induction of angiogenesis. Circ. Heart Fail. 2013, 6, 1077-1086. [CrossRef]

367. Chen, D.B.; Feng, L.; Hodges, J.K.; Lechuga, T.J.; Zhang, H.H. Human trophoblast-derived hydrogen sulfide stimulates placental artery endothelial cell angiogenesis. Biol. Reprod. 2017, 97, 478-489. [CrossRef]

368. Namba, T.; Koike, H.; Murakami, K.; Aoki, M.; Makino, H.; Hashiya, N.; Ogihara, T.; Kaneda, Y.; Kohno, M.; Morishita, R. Angiogenesis induced by endothelial nitric oxide synthase gene through vascular endothelial growth factor expression in a rat hindlimb ischemia model. Circulation 2003, 108, 2250-2257. [CrossRef]

369. Yang, G.; Sun, X.; Wang, R. Hydrogen sulfide-induced apoptosis of human aorta smooth muscle cells via the activation of mitogen-activated protein kinases and caspase-3. FASEB J. 2004, 18, 1782-1784. [CrossRef]

370. Yang, G.; Wu, L.; Wang, R. Pro-apoptotic effect of endogenous H2S on human aorta smooth muscle cells. FASEB J. 2006, 20, 553-555. [CrossRef]

371. Du, J.; Hui, Y.; Cheung, Y.; Bin, G.; Jiang, H.; Chen, X.; Tang, C. The possible role of hydrogen sulfide as a smooth muscle cell proliferation inhibitor in rat cultured cells. Heart Vessels 2004, 19, 75-80. [CrossRef]

372. Lechuga, T.J.; Zhang, H.H.; Sheibani, L.; Karim, M.; Jia, J.; Magness, R.R.; Rosenfeld, C.R.; Chen, D.B. Estrogen Replacement Therapy in Ovariectomized Nonpregnant Ewes Stimulates Uterine Artery Hydrogen Sulfide Biosynthesis by Selectively Up-Regulating Cystathionine beta-Synthase Expression. Endocrinology 2015, 156, 2288-2298. [CrossRef]

373. Lechuga, T.J.; Qi, Q.R.; Magness, R.R.; Chen, D.B. Ovine uterine artery hydrogen sulfide biosynthesis in vivo: Effects of ovarian cycle and pregnancydagger. Biol. Reprod. 2019, 100, 1630-1636. [CrossRef] [PubMed]

374. Kraus, J.P.; Oliveriusova, J.; Sokolova, J.; Kraus, E.; Vlcek, C.; de Franchis, R.; Maclean, K.N.; Bao, L.; Bukovsk, G.; Patterson, D.; et al. The human cystathionine beta-synthase (CBS) gene: Complete sequence, alternative splicing, and polymorphisms. Genomics 1998, 52, 312-324. [CrossRef] [PubMed]

375. Yang, G.; Pei, Y.; Teng, H.; Cao, Q.; Wang, R. Specificity protein-1 as a critical regulator of human cystathionine gamma-lyase in smooth muscle cells. J. Biol. Chem. 2011, 286, 26450-26460. [CrossRef]

376. Li, H.; Mani, S.; Cao, W.; Yang, G.; Lai, C.; Wu, L.; Wang, R. Interaction of hydrogen sulfide and estrogen on the proliferation of vascular smooth muscle cells. PLoS ONE 2012, 7, 1-10. [CrossRef]

377. Mishra, J.S.; te Riele, G.M.; Qi, Q.R.; Lechuga, T.J.; Gopalakrishnan, K.; Chen, D.B.; Kumar, S. Estrogen receptor- $\beta$ mediates estradiol-induced pregnancy-specific uterine artery endothelial cell angiotensin type-2 receptor expression. Hypertension 2019, in press. [CrossRef] [PubMed]

378. D’Emmanuele di Villa Bianca, R.; Mitidieri, E.; Fusco, F.; Russo, A.; Pagliara, V.; Tramontano, T.; Donnarumma, E.; Mirone, V.; Cirino, G.; Russo, G.; et al. Urothelium muscarinic activation phosphorylates CBS(Ser227) via cGMP/PKG pathway causing human bladder relaxation through $\mathrm{H}_{2} \mathrm{~S}$ production. Sci. Rep . 2016, 6, 31491. [CrossRef]

379. Coletta, C.; Papapetropoulos, A.; Erdelyi, K.; Olah, G.; Modis, K.; Panopoulos, P.; Asimakopoulou, A.; Gero, D.; Sharina, I.; Martin, E.; et al. Hydrogen sulfide and nitric oxide are mutually dependent in the regulation of angiogenesis and endothelium-dependent vasorelaxation. Proc. Natl. Acad. Sci. USA 2012, 109, 9161-9166. [CrossRef] [PubMed]

380. Kubo, S.; Doe, I.; Kurokawa, Y.; Nishikawa, H.; Kawabata, A. Direct inhibition of endothelial nitric oxide synthase by hydrogen sulfide: Contribution to dual modulation of vascular tension. Toxicology 2007, 232, 138-146. [CrossRef]

381. Ali, M.Y.; Ping, C.Y.; Mok, Y.Y.; Ling, L.; Whiteman, M.; Bhatia, M.; Moore, P.K. Regulation of vascular nitric oxide in vitro and in vivo; a new role for endogenous hydrogen sulphide? Br. J. Pharmacol. 2006, 149, 625-634. [CrossRef]

382. Filipovic, M.R.; Eberhardt, M.; Prokopovic, V.; Mijuskovic, A.; Orescanin-Dusic, Z.; Reeh, P.; Ivanovic-Burmazovic, I. Beyond $\mathrm{H}_{2} \mathrm{~S}$ and $\mathrm{NO}$ interplay: Hydrogen sulfide and nitroprusside react directly to give nitroxyl (HNO). A new pharmacological source of HNO. J. Med. Chem. 2013, 56, 1499-1508. [CrossRef]

383. Filipovic, M.R.; Miljkovic, J.; Nauser, T.; Royzen, M.; Klos, K.; Shubina, T.; Koppenol, W.H.; Lippard, S.J.; Ivanovic-Burmazovic, I. Chemical characterization of the smallest S-nitrosothiol, HSNO; cellular cross-talk of $\mathrm{H}_{2} \mathrm{~S}$ and S-nitrosothiols. J. Am. Chem. Soc. 2012, 134, 12016-12027. [CrossRef] [PubMed] 
384. Cortese-Krott, M.M.; Fernandez, B.O.; Santos, J.L.; Mergia, E.; Grman, M.; Nagy, P.; Kelm, M.; Butler, A.; Feelisch, M. Nitrosopersulfide (SSNO(-)) accounts for sustained NO bioactivity of S-nitrosothiols following reaction with sulfide. Redox Biol. 2014, 2, 234-244. [CrossRef] [PubMed]

385. Berenyiova, A.; Grman, M.; Mijuskovic, A.; Stasko, A.; Misak, A.; Nagy, P.; Ondriasova, E.; Cacanyiova, S.; Brezova, V.; Feelisch, M.; et al. The reaction products of sulfide and S-nitrosoglutathione are potent vasorelaxants. Nitric. Oxide 2015, 46, 123-130. [CrossRef] [PubMed]

386. Foresti, R.; Motterlini, R. The heme oxygenase pathway and its interaction with nitric oxide in the control of cellular homeostasis. Free Radic. Res. 1999, 31, 459-475. [CrossRef]

387. Thom, S.R.; Xu, Y.A.; Ischiropoulos, H. Vascular endothelial cells generate peroxynitrite in response to carbon monoxide exposure. Chem. Res. Toxicol. 1997, 10, 1023-1031. [CrossRef]

388. Sun, M.W.; Zhong, M.F.; Gu, J.; Qian, F.L.; Gu, J.Z.; Chen, H. Effects of different levels of exercise volume on endothelium-dependent vasodilation: Roles of nitric oxide synthase and heme oxygenase. Hypertens Res. 2008, 31, 805-816. [CrossRef]

389. Kajimura, M.; Shimoyama, M.; Tsuyama, S.; Suzuki, T.; Kozaki, S.; Takenaka, S.; Tsubota, K.; Oguchi, Y.; Suematsu, M. Visualization of gaseous monoxide reception by soluble guanylate cyclase in the rat retina. FASEB J. 2003, 17, 506-508. [CrossRef]

390. Qingyou, Z.; Junbao, D.; Weijin, Z.; Hui, Y.; Chaoshu, T.; Chunyu, Z. Impact of hydrogen sulfide on carbon monoxide/heme oxygenase pathway in the pathogenesis of hypoxic pulmonary hypertension. Biochem. Biophys. Res. Commun. 2004, 317, 30-37. [CrossRef]

391. Jin, H.F.; Du, J.B.; Li, X.H.; Wang, Y.F.; Liang, Y.F.; Tang, C.S. Interaction between hydrogen sulfide/cystathionine gamma-lyase and carbon monoxide/heme oxygenase pathways in aortic smooth muscle cells. Acta Pharmacol. Sin. 2006, 27, 1561-1566. [CrossRef]

392. Polhemus, D.J.; Lefer, D.J. Emergence of hydrogen sulfide as an endogenous gaseous signaling molecule in cardiovascular disease. Circ. Res. 2014, 114, 730-737. [CrossRef]

393. Cunningham, F.; Leveno, K.; Bloom, S.; Spong, C.Y.; Dashe, J. Williams Obstetrics, 24e; Mcgraw-Hill: New York, NY, USA, 2014.

394. Osungbade, K.O.; Ige, O.K. Public health perspectives of preeclampsia in developing countries: Implication for health system strengthening. J. Pregnancy 2011, 2011, 481095. [CrossRef] [PubMed]

395. Sibai, B.M. Diagnosis and management of gestational hypertension and preeclampsia. Obstet. Gynecol. 2003, 102, 181-192. [CrossRef] [PubMed]

396. Sibai, B.; Dekker, G.; Kupferminc, M. Pre-eclampsia. Lancet 2005, 365, 785-799. [CrossRef]

397. Redman, C.W.; Sargent, I.L. Latest advances in understanding preeclampsia. Science 2005, 308, $1592-1594$. [CrossRef]

398. Karumanchi, S.A.; Bdolah, Y. Hypoxia and sFlt-1 in preeclampsia: The "chicken-and-egg" question. Endocrinology 2004, 145, 4835-4837. [CrossRef]

399. Powe, C.E.; Levine, R.J.; Karumanchi, S.A. Preeclampsia, a disease of the maternal endothelium: The role of antiangiogenic factors and implications for later cardiovascular disease. Circulation 2011, 123, 2856-2869. [CrossRef]

400. Stamilio, D.M.; Sehdev, H.M.; Morgan, M.A.; Propert, K.; Macones, G.A. Can antenatal clinical and biochemical markers predict the development of severe preeclampsia? Am. J. Obstet. Gynecol. 2000, 182, 589-594. [CrossRef]

401. Gerretsen, G.; Huisjes, H.J.; Elema, J.D. Morphological changes of the spiral arteries in the placental bed in relation to pre-eclampsia and fetal growth retardation. Br. J. Obstet. Gynaecol. 1981, 88, 876-881. [CrossRef]

402. Van Beck, E.; Peeters, L.L. Pathogenesis of preeclampsia: A comprehensive model. Obstet. Gynecol. Surv. 1998, 53, 233-239. [CrossRef]

403. Magness, R.R.; Rosenfeld, C.R. The role of steroid hormones in the control of uterine blood flow. Uterine Circ. 1989, 10, 239-271.

404. Jobe, S.O.; Tyler, C.T.; Magness, R.R. Aberrant synthesis, metabolism, and plasma accumulation of circulating estrogens and estrogen metabolites in preeclampsia implications for vascular dysfunction. Hypertension 2013, 61, 480-487. [CrossRef] [PubMed]

405. Kanasaki, K.; Palmsten, K.; Sugimoto, H.; Ahmad, S.; Hamano, Y.; Xie, L.; Parry, S.; Augustin, H.G.; Gattone, V.H.; Folkman, J.; et al. Deficiency in catechol-O-methyltransferase and 2-methoxyoestradiol is associated with pre-eclampsia. Nature 2008, 453, 1117-1121. [CrossRef] [PubMed] 
406. Nobunaga, T.; Tokugawa, Y.; Hashimoto, K.; Kimura, T.; Matsuzaki, N.; Nitta, Y.; Fujita, T.; Kidoguchi, K.I.; Azuma, C.; Saji, F. Plasma nitric oxide levels in pregnant patients with preeclampsia and essential hypertension. Gynecol. Obstet. Investig. 1996, 41, 189-193. [CrossRef] [PubMed]

407. Smarason, A.K.; Allman, K.G.; Young, D.; Redman, C.W. Elevated levels of serum nitrate, a stable end product of nitric oxide, in women with pre-eclampsia. Br. J. Obstet. Gynaecol. 1997, 104, 538-543. [CrossRef]

408. Davidge, S.T.; Stranko, C.P.; Roberts, J.M. Urine but not plasma nitric oxide metabolites are decreased in women with preeclampsia. Am. J. Obstet. Gynecol. 1996, 174, 1008-1013. [CrossRef]

409. Roberts, J.M.; Taylor, R.N.; Musci, T.J.; Rodgers, G.M.; Hubel, C.A.; McLaughlin, M.K. Preeclampsia: An endothelial cell disorder. Am. J. Obstet. Gynecol. 1989, 161, 1200-1204. [CrossRef]

410. Mitchell, B.M.; Cook, L.G.; Danchuk, S.; Puschett, J.B. Uncoupled endothelial nitric oxide synthase and oxidative stress in a rat model of pregnancy-induced hypertension. Am. J. Hypertens. 2007, 20, 1297-1304. [CrossRef]

411. Radi, R.; Beckman, J.S.; Bush, K.M.; Freeman, B.A. Peroxynitrite-induced membrane lipid peroxidation: The cytotoxic potential of superoxide and nitric oxide. Arch. Biochem. Biophys. 1991, 288, 481-487. [CrossRef]

412. Kublickiene, K.R.; Lindblom, B.; Kruger, K.; Nisell, H. Preeclampsia: Evidence for impaired shear stress-mediated nitric oxide release in uterine circulation. Am. J. Obstet. Gynecol. 2000, 183, 160-166. [CrossRef]

413. Lyall, F.; Barber, A.; Myatt, L.; Bulmer, J.N.; Robson, S.C. Hemeoxygenase expression in human placenta and placental bed implies a role in regulation of trophoblast invasion and placental function. FASEB J. 2000, 14, 208-219. [CrossRef]

414. Lyall, F. Development of the utero-placental circulation: The role of carbon monoxide and nitric oxide in trophoblast invasion and spiral artery transformation. Microsc. Res. Technol. 2003, 60, 402-411. [CrossRef] [PubMed]

415. Venditti, C.C.; Casselman, R.; Murphy, M.S.; Adamson, S.L.; Sled, J.G.; Smith, G.N. Chronic carbon monoxide inhalation during pregnancy augments uterine artery blood flow and uteroplacental vascular growth in mice. Am. J. Physiol. Regul. Integr. Comp. Physiol. 2013, 305, R939-R948. [CrossRef] [PubMed]

416. Miles, E.W.; Kraus, J.P. Cystathionine beta-synthase: Structure, function, regulation, and location of homocystinuria-causing mutations. J. Biol. Chem. 2004, 279, 29871-29874. [CrossRef] [PubMed]

417. Hu, T.; Wang, G.; Zhu, Z.; Huang, Y.; Gu, H.; Ni, X. Increased ADAM10 expression in preeclamptic placentas is associated with decreased expression of hydrogen sulfide production enzymes. Placenta 2015, 36, 947-950. [CrossRef] [PubMed]

418. Holwerda, K.M.; Burke, S.D.; Faas, M.M.; Zsengeller, Z.; Stillman, I.E.; Kang, P.M.; van Goor, H.; McCurley, A.; Jaffe, I.Z.; Karumanchi, S.A.; et al. Hydrogen sulfide attenuates sFlt1-induced hypertension and renal damage by upregulating vascular endothelial growth factor. J. Am. Soc. Nephrol. 2014, 25, 717-725. [CrossRef]

419. Cindrova-Davies, T.; Herrera, E.A.; Niu, Y.; Kingdom, J.; Giussani, D.A.; Burton, G.J. Reduced cystathionine gamma-lyase and increased miR-21 expression are associated with increased vascular resistance in growth-restricted pregnancies: Hydrogen sulfide as a placental vasodilator. Am. J. Pathol. 2013, 182, 1448-1458. [CrossRef]

420. Babic, G.M.; Markovic, S.D.; Varjacic, M.; Djordjevic, N.Z.; Nikolic, T.; Stojic, I.; Jakovljevic, V. Estradiol decreases blood pressure in association with redox regulation in preeclampsia. Clin. Exp. Hypertens. 2018, 40, 281-286. [CrossRef]

421. Djordjevic, N.Z.; Babic, G.M.; Markovic, S.D.; Ognjanovic, B.I.; Stajn, A.S.; Saicic, Z.S. The antioxidative effect of estradiol therapy on erythrocytes in women with preeclampsia. Reprod. Toxicol. 2010, 29, 231-236. [CrossRef]

422. Yallampalli, C.; Garfield, R.E. Inhibition of nitric oxide synthesis in rats during pregnancy produces signs similar to those of preeclampsia. Am. J. Obstet. Gynecol. 1993, 169, 1316-1320. [CrossRef]

423. Johal, T.; Lees, C.C.; Everett, T.R.; Wilkinson, I.B. The nitric oxide pathway and possible therapeutic options in pre-eclampsia. Br. J. Clin. Pharmacol. 2014, 78, 244-257. [CrossRef]

424. De Belder, A.; Lees, C.; Martin, J.; Moncada, S.; Campbell, S. Treatment of HELLP syndrome with nitric oxide donor. Lancet 1995, 345, 124-125. [CrossRef]

425. Lees, C.; Langford, E.; Brown, A.S.; de Belder, A.; Pickles, A.; Martin, J.F.; Campbell, S. The effects of S-nitrosoglutathione on platelet activation, hypertension, and uterine and fetal Doppler in severe preeclampsia. Obstet. Gynecol. 1996, 88, 14-19. [CrossRef] 
426. Vadillo-Ortega, F.; Perichart-Perera, O.; Espino, S.; Avila-Vergara, M.A.; Ibarra, I.; Ahued, R.; Godines, M.; Parry, S.; Macones, G.; Strauss, J.F. Effect of supplementation during pregnancy with L-arginine and antioxidant vitamins in medical food on pre-eclampsia in high risk population: Randomised controlled trial. BMJ 2011, 342, d2901. [CrossRef] [PubMed]

427. Dorniak-Wall, T.; Grivell, R.M.; Dekker, G.A.; Hague, W.; Dodd, J.M. The role of L-arginine in the prevention and treatment of pre-eclampsia: A systematic review of randomised trials. J. Hum. Hypertens. 2014, 28, 230-235. [CrossRef] [PubMed]

428. Trapani, A., Jr.; Goncalves, L.F.; Trapani, T.F.; Vieira, S.; Pires, M.; Pires, M.M. Perinatal and Hemodynamic Evaluation of Sildenafil Citrate for Preeclampsia Treatment: A Randomized Controlled Trial. Obstet. Gynecol. 2016, 128, 253-259. [CrossRef]

429. Lombardi, N.; Crescioli, G.; Bettiol, A.; Ravaldi, C.; Vannacci, A. Perinatal deaths after sildenafil treatment of fetal growth restriction raise the issue of safety in randomised clinical trials. Pharmacoepidemiol. Drug Saf. 2019, 28, 437-438. [CrossRef]

430. Goldstein, J.L.; Brown, M.S. The LDL receptor. Arterioscler Thromb. Vasc. Biol. 2009, 29, 431-438. [CrossRef]

431. Ludman, A.; Venugopal, V.; Yellon, D.M.; Hausenloy, D.J. Statins and cardioprotection-More than just lipid lowering? Pharmacol. Ther. 2009, 122, 30-43. [CrossRef]

432. Weis, M.; Heeschen, C.; Glassford, A.J.; Cooke, J.P. Statins have biphasic effects on angiogenesis. Circulation 2002, 105, 739-745. [CrossRef]

433. Cudmore, M.; Ahmad, S.; Al-Ani, B.; Fujisawa, T.; Coxall, H.; Chudasama, K.; Devey, L.R.; Wigmore, S.J.; Abbas, A.; Hewett, P.W.; et al. Negative regulation of soluble Flt-1 and soluble endoglin release by heme oxygenase-1. Circulation 2007, 115, 1789-1797. [CrossRef]

434. Muchova, L.; Wong, R.J.; Hsu, M.; Morioka, I.; Vitek, L.; Zelenka, J.; Schroder, H.; Stevenson, D.K. Statin treatment increases formation of carbon monoxide and bilirubin in mice: A novel mechanism of in vivo antioxidant protection. Can. J. Physiol. Pharmacol. 2007, 85, 800-810. [CrossRef] [PubMed]

435. Maierean, S.M.; Mikhailidis, D.P.; Toth, P.P.; Grzesiak, M.; Mazidi, M.; Maciejewski, M.; Banach, M. The potential role of statins in preeclampsia and dyslipidemia during gestation: A narrative review. Expert Opin. Investig. Drugs 2018, 27, 427-435. [CrossRef]

436. Banerjee, S.K.; Maulik, S.K. Effect of garlic on cardiovascular disorders: A review. Nutr. J. $2002,1,4$. [CrossRef] [PubMed]

437. Benavides, G.A.; Squadrito, G.L.; Mills, R.W.; Patel, H.D.; Isbell, T.S.; Patel, R.P.; Darley-Usmar, V.M.; Doeller, J.E.; Kraus, D.W. Hydrogen sulfide mediates the vasoactivity of garlic. Proc. Natl. Acad. Sci. USA 2007, 104, 17977-17982. [CrossRef] [PubMed]

(C) 2020 by the authors. Licensee MDPI, Basel, Switzerland. This article is an open access article distributed under the terms and conditions of the Creative Commons Attribution (CC BY) license (http://creativecommons.org/licenses/by/4.0/). 